\title{
THE OLENEKIAN-ANISIAN/EARLY-MIDDLE TRIASSIC BOUNDARY, AND ASSESSMENT OF THE POTENTIAL OF CONODONTS FOR CHRONOSTRATIGRAPHIC CALIBRATION OF THE TRIASSIC TIMESCALE
}

\author{
Eugen Grădinaru
}

Received: 22 November 2020 / Accepted: 19 November 2021 / Published online: 6 December 2021

\begin{abstract}
The conodont Chiosella timorensis (Nogami, 1968) has for a long time been considered to be a suitable biotic proxy for the Olenekian-Anisian/Early-Middle Triassic boundary. The recently acquired ammonoid record around that boundary clearly shows that the FAD of this conodont is located well below the boundary, i.e., in the late Spathian. In the present paper, it is underlined that the conodont Chiosella timorensis was promoted as a proxy for the nominated boundary in the early 1980s when the ammonoid record around the boundary was not yet well established. On the other side, until the mid 1990s the taxonomic definition and the lineage of the conodont Chiosella timorensis were not well stated, and even now there are still controversial interpretations of the taxonomic content of this conodont species. The new data achieved from the ammonoid/conodont record around the nominated boundary, especially in the western USA, and also in the Deşli Caira section in Romania, firmly demonstrate that the conodont Chiosella timorensis is a defunct proxy for the Olenekian-Anisian/Early-Middle Triassic boundary. As a consequence, the present data on the ammonoid-documented Olenekian-Anisian/Early-Middle Triassic boundary requires the recalibration of all physical events that have been tied to the FAD of the conodont Chiosella timorensis. The case of the Albanian Kçira-section, for which the chronostratigraphic interpretation of the ammonoid record is proved incorrect, definitely makes the conodont Chiosella timorensis a defunct proxy for the nominated boundary. Also, the case of the two Chinese sections recently proposed as being "exceptional" GSSP candidates for the Early-Middle Triassic boundary, which is based on an inconsistent ammonoid/conodont biochronology, fully strengthens this conclusion. The history of the controversial usage of the conodont species Chiosella timorensis in defining the Olenekian-Anisian boundary justifies a discussion about the usefulness of conodonts in the chronostratigraphic calibration of the standard Triassic timescale. One may conclude that the conodonts are not qualified, and have not a reasonable potential, to be used to define or to redefine the boundaries of chronostratigraphic units in the standard Triassic timescale, which have been basically defined on ammonoid biochronology.
\end{abstract}

Keywords: Chiosella timorensis, late Spathian FAD, base Anisian GSSP candidates, defunct biotic proxy, conodonts, Triassic chronostratigraphic scale.

\section{INTRODUCTION}

Muttoni et al. (2019) claimed that a relatively thick and stratigraphically complete Kçira-A section in Albania has "excellent" potential as a candidate Global Boundary Stratotype Section and Point (GSSP) for the OlenekianAnisian boundary (OAB), i.e., the base of the Anisian Stage of the Triassic System, which is the base of the Middle Triassic Series. Muttoni et al. (2019) summarized key magneto-biostratigraphical aspects of the Kçira-A and ancillary sections from the Kçira area of northern Albania. It is assumed that the well-defined magnetic polarity reversal pattern of primary origin allows global correlation, ensuring the exportability of biostratigraphic datums, e.g., the occurrence of the conodont Chiosella timorensis falling close to the $\mathrm{Kclr} / \mathrm{Kc} 2 \mathrm{n}$ polarity transition. By adding the carbon and oxygen isotope stratigraphy, Muttoni et al. (2019) concluded that with additional studies the Kçira-A section would represent an ideal base Anisian GSSP.

Ogg (2019) and Chen Y et al. (2020) claimed that the Wantou and Youping sections of Guangxi, South China, are "exceptional" sections, unique across the Early to Middle Triassic boundary interval in their combination of magnetostratigraphy, conodont-rich strata, and ammonoids. The authors especially underlined that the Wantou section represents a potential international GSSP reference section for simultaneously defining and dating of the Early-Middle Triassic boundary and the base of the Anisian Stage. Moreover, the authors asserted that, in addition to the conodont biostratigraphy, both sections have been researched for ammonoid datums. Although the ammonoid record in the Chinese sections is very diffuse, it is concluded, however, that the two Chinese sections would provide an "independent biostratigraphy" for correlation with ammonoid-dominated sections in other regions.

The proposals advanced by Muttoni et al. (2019), on one side, and by Ogg (2019) and Chen Y et al. (2020), on the other side, led us to unravel the real data on the ammonoid-tied conodont biostratigraphy around the OlenekianAnisian/Early-Middle Triassic boundary in the Albanian and Chinese sections. In the following sections we will present and comment on the lithology, the ammonoid and conodont records in the Albanian Kçira-A section and the Chinese Wantou section, and their relevance to discussing the Olenekian-Anisian/Early-Middle Triassic boundary $(\mathrm{OAB} / \mathrm{EMTB})$.

\footnotetext{
${ }^{1}$ Department of Geology, Faculty of Geology and Geophysics, University of Bucharest, Bd. Bălcescu Nicolae 1, RO-010041 
The discussion of the historical background that for a long time supported the suitability of the conodont species Chiosella timorensis (Nogami, 1968) as a primary biotic proxy for the OAB concludes it is a defunct proxy for the nominated boundary. This prompted us to discuss in the second part of the present paper the potential of conodonts for chronostratigraphic calibration of the Triassic timescale, and to conclude, with significant examples, that the conodonts are not qualified to contribute to the defining or redefining of the chronostratigraphic units and their boundaries in the standard Triassic timescale that is basically built on the ammonoid biochronolgy, and for which the conodonts had no a historical contribution.

The definition of the OAB/EMTB must follow the rules governing the standardization of the chronostratigraphic scale through the definition of chronostratigraphic boundaries by Global Stratotype Sections and Points (GSSPs). Discussing the GSSP philosophy and methodology, Lucas (2018a, 2019) stated that the GSSP is a point (stratigraphic level) in a specific location (stratigraphic section) that defines the base of a stage. Further on, the author underlined that a GSSP is correlated by a primary signal, usually a biostratigraphic datum, and by secondary signals - biostratigraphic, chemostratigraphic, magnetostratigraphic, and radiosotopic, among others. As Finney (2013) and Lucas (2018a) emphasized, the primary signal should be correlatable over a broad area, and there should be secondary signals (proxies) to support that correlation and that may provide correlation to places where the primary signals is absent. Moreover, Lucas (2018a, 2020b) distinguished biostratigraphic datums from biochronological events. Biostratigraphic datums are the lowest occurrence (LO) and highest occurrence (HO) of a fossil in a stratigraphic section. Biochronological events are the first appearance datum (FAD) and last appearance datum (LAD) of a taxon, its evolutionary origination and extinction, respectively. For chronostratigraphic definition, it is hoped that the LO and the FAD of a taxon coincide, at least if it is the primary signal for correlation of a GSSP. Imprecision in GSSP correlation may occur when the primary signals are largely single taxon biotic events that are inherently diachronous due to the limitations of fossil distributions by sampling, facies and provincialism. Indeed, the primary signal is usually a perceived evolutionary change (origin of a new taxon) in an evolving lineage. With regard of the biostratigraphic requirements, Lucas (2019) noted that the GSSP strata should yield abundant and diverse fossils in order to provide the best opportunity to identify signals for correlation based on fossils. These fossils should be useful for long-range correlation, so they are most likely to be fossils of marine organisms that lived in an open marine environment. These include, but are not limited to, microfossils such as conodonts, radiolarians, foraminiferans and calcareous nannoplankton, and macrofossils such as ammonoids, in the case of the Triassic System. There should be no changes in facies vertically through the GSSP level to insure that biotic changes in the section are not simply the result of local sedimentological or paleoecological events.

Among the other methods of correlation, as Lucas (2019) underlined, the non-biostratigraphic data have been proven to be useful for correlation and include radioisotopic dating, magnetostratigraphy, chemostratigraphy and sequence stratigraphy. Numerical calibration of the age of a GSSP or in the GSSP section can help to establish correlations to other, numerically dated locations, as can a magnetic reversal stratigraphy that is able to be replicated. A record of changes in stable isotopes may provide a correlation to global events that left a geochemical signature. Sequence stratigraphic analysis can sometimes provide correlations to other sections that record the same depositional history of base-level changes. All of these, and other, non-biostratigraphic tools for correlation can provide secondary signals for a GSSP, and some Phanerozoic GSSPs have already been defined using nonbiostratigraphic signals as their primary signal (Lucas, 2019).

To the above statements, we must underline that major shorthcomings in defining a GSSP may occur from the fact that naturally there are no complete records of biotic and non-biotic events in any rock sequence, and, consequently, these are not properly replicated worldwide. Almost all of the ratified GSSPs ignore that the incompleteness in the geological record is a natural feature, and their promoters frantically support them as being "perfect" for global correlation.

In the next sections of the present paper, we will discuss the various GSSP candidates for the OAB/EMTB. In some cases, biotic events, either ammonoids or conodonts, are prevalent in defining the nominated boundary. On the other side, there are, however, attempts to give a prevalence to the non-biotic events as is seen even from the titles of some papers (e.g., Hounslow et al., 2007; Muttoni et al., 1998, 2019; Ogg, 2019; Chen Y et al., 2020).

Lucas et al. (2007) and Lucas (2007) stated that the definition of a GSSP level (point) has to begin with a primary marker or event (biotic or non-biotic), whilst other biotic or non-biotic markers or events that are temporally close to the primary marker are categorized as secondary markers or proxies. Furthermore, proxies can provide correlations to localities where the primary marker is absent. With regard to the FOs of the conodont species Chiosella timorensis, long-time promoted as a primary biotic event for the $\mathrm{OAB} / \mathrm{EMTB}$, in most cases the definition of its FOs given by different authors doesn't fulfill the distinction of biostratigraphic datums from biochronological events, as these are defined by Lucas (2018a, 2020b). So, with regard to the status of the conodont species $C h$. timorensis as a primary biotic marker for the $\mathrm{OAB} / \mathrm{EMTB}$, in opposition to other secondary biotic or non-biotic markers, which are classified as proxies by Lucas (2007), one may observe that the status of this conodont species either as a primary biotic marker or as a proxy is not properly defined, especially when the FO of 
ammonoids is promoted as a primary biotic marker. As an example, Assereto et al. (1980) firstly noted that in Chios (Greece) the beginning of the Anisian is marked by the first appearance of the cladiscitid ammonoids, although later this was proved incorrect, and this would also coincide with the first occurrence of the conodont species Neogondolella (= Chiosella) timorensis. In this case, the conodont species Ch. timorensis served as a secondary biotic marker, i.e., as a proxy. After that, Gaetani et al. (1992) concluded that at Chios the base of the Anisian Stage may be traced with the FAD of the ammonoids Aegeiceras, Paracrochordiceras, Paradanubites and Japonites, and that the FAD of the conodont species Gondolella (= Chiosella) timorensis slightly precedes the ammonoid FAD. In this case, this conodont species lost its status even as a proxy. On the other side, Muttoni et al. $(1994,1995,1996,1998,2019)$ have payed credit, however, to the conodont biostratigraphy, i.e., to the FO of Ch. timorensis, and to its concurrent magnetostratigraphy in discussing the Early-Middle Triassic chronostratigraphy in the Chios (Greece) and Kçira (Albania) sections, and advanced, like Hounslow \& Muttoni (2010) and Hounslow et al. $(2007,2008)$, the proposal to define the base of the Anisian Stage using a magnetozone datum. Thus, these authors advanced a non-biotic marker as a primary marker for the $\mathrm{OAB}$, with the $\mathrm{FO}$ of $C h$. timorensis as a secondary biotic marker, i.e., as a proxy. Very recently, Chen Y et al. (2020), when discussing the Early-Middle Triassic boundary interval in the Chinese Wantou and Youping sections, both being proposed as "exceptional" potential GSSPs for the base of the Anisian Stage, concluded that the combination of the FO of conodont Chiosella timorensis s.s., the brief normal polarity zone (MT1n) and the last portion of the rising carbonisotope trend are "all" suitable as "primary proxies" for global correlation of the Early-Middle Triassic boundary. In consequence, as the base of the Anisian Stage is not documented by the ammonoid biochronology in any Chinese sections, the ammonoid first occurrence is not used as a primary biotic marker, or even as a proxy, to define the $\mathrm{OAB}$ in these sections.

As the standard Triassic timescale is based on ammonoid biochronology, whilst the ranking of the diagnostic markers segregates them as primary markers or secondary markers, the last ones being clasified as proxies, it is beyond any doubt that the Olenekian-Anisian/Early-Middle Triassic boundary (OAB/EMTB) must be mandatory defined by the FAD of diagnostic ammonoids, as a primary biotic marker. In this case, all other secondary biotic markers, like the FO of diagnostic conodonts, and all non-biotic events, such as magnetostratigraphic, chemostratigraphic and others, may be used only as proxies to evaluate the synchrony of the primary biotic marker at different localities (see Lucas, 2007).

The recent ammonoid/conodont biochronology in the Deşli Caira section (Grădinaru, in Grădinaru \& Gaetani, 2018; Golding, 2021a) prompted the FAD of the Paracrochordiceras and Aegeiceras ammonoid assem- blage as the primary biotic marker for the OAB/EMTB, whilst the conodont species Chiosella timorensis, the FAD of which is now well bellow the OAB/EMTB, is disqualified to be used either as a primary biotic marker or as a secondary biotic marker/proxy for the nominated boundary, as it was promoted for a long time in the numerous dedicated publications.

\section{THE ALBANIAN KÇIRA SECTION, AN ALLEGED GSSP FOR THE OLENEKIAN-ANISIAN BOUND- ARY}

\section{Lithology}

The Kçira-A section, about $42 \mathrm{~m}$ thick, as reported by Muttoni et al. (1996, 2019), consists of reddish to pale pink wackestones and mudstones arranged in cm-thick nodular beds that are strongly amalgamated to form meter-scale composite layers. Within the nodular limestone succession of the Kçira-A section, the authors separate four lithological units, as follows:

- Unit I, covering the basal $4.8 \mathrm{~m}$ of the Kçira-A section, is reddish and clay-rich, with pervasive, bedding-parallel stylolites;

- $\quad$ Unit II, following after a $3.7 \mathrm{~m}$ gap, is made up of pink, amalgamated nodular limestones;

- Unit III, with pale pink nodular limestones, which in the interval 18 to $23 \mathrm{~m}$ has a set of cmthick calcite veins that cut the bedding;

- Unit IV, more distinctly bedded, consists of packstones, more pink and richer in bioclasts;

Small neptunian dikes sealed by a cm-thick silicified crust, of uncertain age, are reported from the top of the Kçira-A section.

\section{Ammonoid record}

According to the monographic work published by Germani (1997), the following ammonoid succession is recorded in the Kçira-A section, in descending stratigraphic order:

- AK57, level $41.80 \mathrm{~m}$ - Procladiscites brancoi (Mojsisovics, 1882), Sturia sp.;

- $\quad$ AK40, level 28.50 m - Leiophyllites sp.;

- AK38, level 27.40 m - Procarnites kokeni (Arthaber, 1908);

- AK36, level $26.02 \mathrm{~m}$ - Leiophyllites sp. cf. L. pitamaha (Diener, 1895);

- AK31, level 23.20 m - Eophyllites sp., Leiophyllites sp. cf. L. pitamaha (Diener, 1895), Leiophyllites sp., Procarnites sp.;

- $\quad \mathrm{AK} 2$ bis and AK5, in the interval 0.75 to $1.25 \mathrm{~m}$ - a rich and diverse ammonoid fauna assigned to the Subcolumbites-Prohungarites zone sensu Kummel (1973a, b).

The rich and diverse ammonoid assemblage of the AK2 bis and AK5, located in Unit I, is dated by Germani (1997) as middle Spathian. Unit II is a barren interval for 
ammonoids. The ammonoids from the level AK31 to AK40, all located in Unit III, are dated by Germani (1997) as Aegean/lower Anisian.

\section{Conodont record}

Taking into account the conodont species considered by Muttoni et al. $(1996,2019)$ and Germani (1997) to have biochronostratigraphic relevance, the following conodonts are recorded in the Kçira-A section, in descending stratigraphic order:

AK40, level $28.70 \mathrm{~m}$ - Paragondolella bulgarica (Budurov \& Stefanov, 1975);

- AK30, level $22.40 \mathrm{~m}$ - Chiosella timorensis (Nogami, 1968).

The conodont Chiosella timorensis is considered by Muttoni et al. (1996, 2019) and Germani (1997) as the leading biotic marker for the base Aegean Substage/early Anisian Stage, whereas the conodont Paragondolella bulgarica is considered as the leading proxy for the base of the Bithynian Substage/lower middle Anisian Stage (Nicora, 1977; Muttoni et al., 1996, 2019; Germani, 1997; Meço, 1999).

\section{Comments}

As regards the lithology of the Kçira-A section, a clayrich succession of nodular limestones, it indicates a deepwater depositional environment, which is commonly characterized by strong carbonate disolution and enrichment in clay, and consequently is responsible for significant condensation. The presence of the pervasive bedding-parallel stylolitisation is a by-product of either a reduced rate of sedimentation or a diagnostic feature, demonstrated also by the presence of the neptunian dikes, which indicate syn-sedimentary tectonism and interruption of sedimentation. In such circumstances, the deepwater limestone sedimentation of the Kçira-A section did not ensure a stability of the paleonvironmental conditions. This explains the paucity and also the discontinuous record of the macrobiota, especially of the ammonoids, which are pivotal for defining the Triassic chronostratigraphic units in the Kçira-A section (Fig. 1).

With regard to the ammonoid record in the Kçira-A section, the ammonoid assemblages of the AK2bis to AK40 are all entirely characterized by typical Spathian ammonoids. The ammonoid Procarnites, with its species Procarnites kokeni (Arthaber, 1908), which is unanimously and unambiguously recognized as an iconic ammonoid for the Spathian (Diener, 1915; Renz \& Renz, 1948; Kutassy, 1932; Spath, 1934; Kummel,1969; Shevyrev, 1968, 1986, 1990; Tozer, 1967, 1971, 1980; Brayard et al., 2006, 2009), is recorded in the Kçira-A section from the middle Spathian AK2bis level till the inferred Aegean AK31 and AK38 levels. This is also the case with the ammonoid Eophyllites, having the $\mathrm{HO}$ in the inferred Aegean AK31 level, which is also unambiguously recognized in all of the above mentioned references as a
Spathian ammonoid. The ammonoid Leiophyllites, recorded at levels AK31, AK36 and AK40, in the stratigraphic interval assigned to the inferred Aegean Substage, has a long biostratigraphic range, which straddles the Olenekian-Anisian/Early-Middle Triassic boundary, and thus this ammonoid does not have any relevance for this boundary. In the upper part of the Kçira-A section, the two ammonoids of the level AK57, located in Unit IV, Procladiscites brancoi (Mojsisovics, 1882) and Sturia sp., are assigned by Germani (1997) to the Pelsonian. It is pretty evident in the Kçira-A section there are no diagnostic ammonoids for the Aegean and the Bithynian substages of the Anisian Stage. The ammonoids from the level AK57, Procladiscites brancoi (Mojsisovics, 1882) and Sturia sp., may be eventually indicative of the Pelsonian, but this does not preclude even a Bithynian age. In spite of this undeniable evidence, Muttoni at al. (1996, 2019) and Germani (1997) intriguingly assigned to the Aegean Substage the interval between level $22.40 \mathrm{~m}$, corresponding to the FO of the conodont Chiosella timorensis, and the level $28.70 \mathrm{~m}$, corresponding to the FO of the conodont Paragondolella bulgarica.

Taking into account the HO of the ammonoid Procarnites kokeni in the Kçira-A section, at the level AK38 (27.40 $\mathrm{m})$, and the FO of the conodont Paragondolella bulgari$c a$, at the level AK40 (28.70 m), the latter being considered a proxy for the base of the Bithynian Substage by a few authors (e.g., Nicora, 1977; Kozur, 2003a; Krystyn et al., 2004; Ji et al., 2011), the remaining interval in the Kçira-A section possibly referable to the Aegean Substage could be eventually limited to a succession less than $1.30 \mathrm{~m}$ thick. This suggests the Aegean Substage is strongly condensed in the Kçira-A section, due probably either to a very reduced rate of sedimentation, coupled with submarine dissolution, or interruptions in sedimentation. The upper part of Unit III lacks ammonoids, and only the occurrence of the conodont Paragondolella bulgarica is indicative of a Bithynian age for this part of the succession in the Kçira-A section. On the other side, the suitability of the conodont $P$. bulgarica as a reliable proxy for the base of the Bithynian Substage is under question. In North America, P. bulgarica does not appear until the ammonoid Hollandites minor Zone, which is middle-Middle Anisian (Orchard \& Tozer, 1997a), and thus higher than the Aegean-Bithynian boundary in Tethys, while Chen Y-L et al. (2016) and Sun et al. (2021) also place the FO of $P$. bulgarica higher in the Bithynian. This underscores questions regarding not only the extent of the Aegean Substage but also the presence of the lower part of the Bithynian Substage in the Kçira-A section.

The root of the incorrect interpretation by Muttoni et al. (1996, 2019), Germani (1997) and Meço (1999) of the chronostratigraphic value of the ammonoid Procarnites kokeni (Arthaber, 1908) is to be found in the untenable assertion made by Assereto et al. (1980), who interpreted as Aegean the ammonoid association of the cladisticids and Procarnites kokeni in the Chios section. As already noted above, the ammonoid Procarnites is a typical 

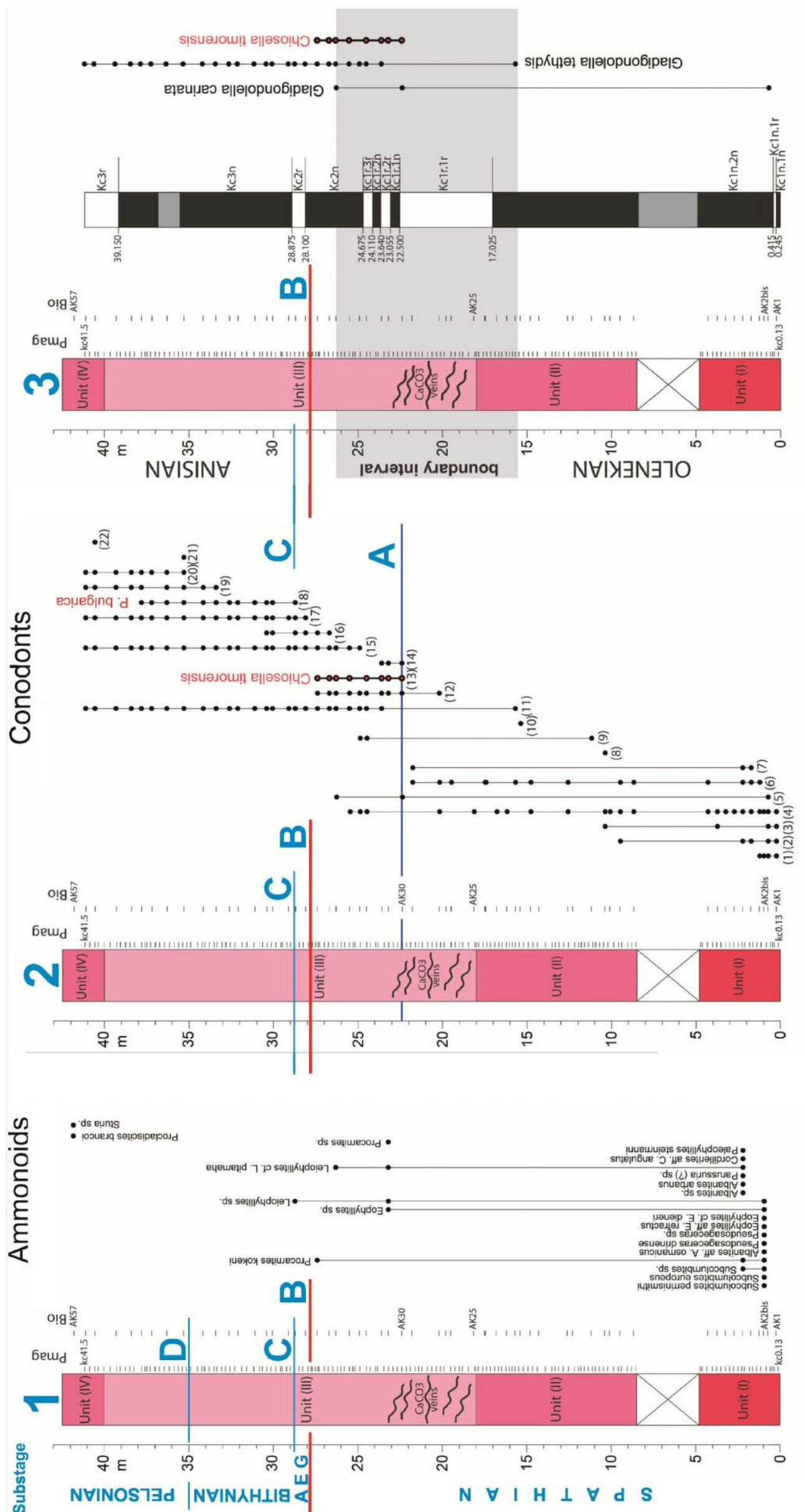

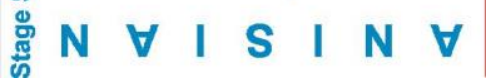

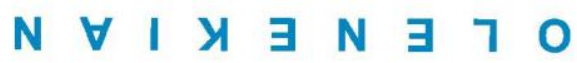

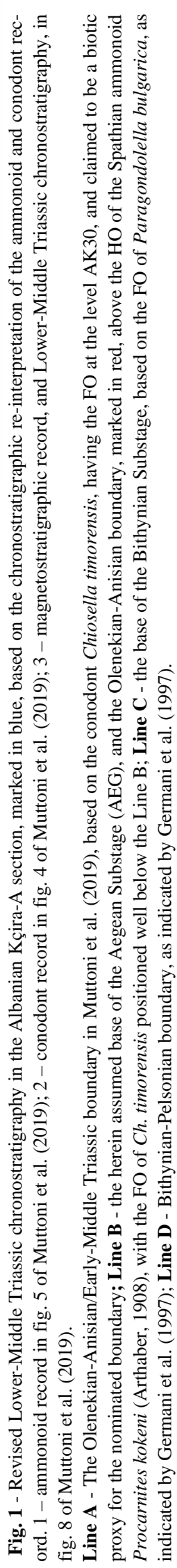


Spathian ammonoid. As regards the interpretation of the conodont Chiosella timorensis as a proxy for the base Aegean, this has its root also in the assertion by Assereto et al. (1980) that the association of Neogondolella timorensis (=Ch. timorensis) with the above-mentioned ammonoid association in the Chios section supports the opinion of Nicora (1977) that this conodont is typical of the lowermost Anisian.

With regard to the FAD of the conodont Paragondolella bulgarica, nominated by Nicora (1977) as a proxy for the base Bithynian, defined by the ammonoid Osmani Zone, it must be also underlined that, as Assereto (1974) already stated, in Bithynia the late Lower Triassic Homeri conodont fauna is found about $350 \mathrm{~m}$ below the Middle Anisian ammonoid Osmani Zone, a stratigraphic interval that is barren of ammonoids. Till now, the Northwestern Caucasus (Shevyrev,1995, 1996, 2000), North Dobrogea (Grădinaru, 2000) and Spiti (Balini \& Krystyn, 1997; Krystyn et al., 2004), where there are potentially continuous ammonoid-bearing stratigraphic successions having the contiguous Anisian substages of the Aegean and the Bithynian in close sequence, are the only Tethyan locations where the study of the conodont successions might eventually demonstrate, or not, the adequacy of Paragondolella bulgarica as a valid proxy for the base of the $\mathrm{Bi}$ thynian.

With reference to the above mentioned ammonoid succession in the Kçira-A section, it is worth mentioning that Gaetani (1994) correctly underlined that basal Anisian ammonoid assemblages are not preserved in the section, so this does not seem suitable as a GSSP candidate for the Olenekian-Anisian boundary. As a consequence, based on the above comments, a revised Lower-Middle Triassic chronostratigraphy in the Albanian Kçira-A section is here advanced in Fig. 1.

Amazingly, Muttoni et al. (2019), obsessively supporting the conodont Chiosella timorensis as a primary biotic proxy for the OAB, fully ignored the already published data by Goudemand et al. (2012) and Ovtcharova et al. (2015), who demonstrated that the FAD of Ch. timorensis is in the latest Spathian Haugi ammonoid zone in Nevada. Having in view the incorrect chronostratigraphic interpretation of the ammonoids as reported by Muttoni et al. (1996, 2019) and Germani (1997) from the levels AK31 till AK40, which are undoubtedly Spathian and not Aegean in age, as demonstrated above, the Kçira-A section is the tombstone under which the conodont $C h$. timorensis, for a long time believed to be a suitable primary proxy for the Spathian-Aegean/Olenekian-Anisian/Early-Middle Triassic boundary, will be resting forever. The true chronostratigraphic significance of the ammonoids in the above mentioned stratigraphic interval has been altered and practically subordinated to the desire to further promote Ch. timorensis as a valid proxy for the discussed boundary. As a consequence, the Kçira-A section is not qualified to be proposed as a candidate Global Boundary Stratotype Section and Point (GSSP) for the base of the Anisian Stage.
THE CHINESE WANTOU SECTION, AN OTHER ALLEGED GSSP FOR THE OLENEKIANANISIAN BOUNDARY

Chen Y et al. (2020) studied two sections in South China, Wantou and Youping, from which the Wantou section is considered by the authors to be one "exceptional" among other South China sections, for obtaining an integrated high-resolution magnetostratigraphy, conodont sequence and carbon-isotope chemostratigraphy. The authors concluded that the unique Wantou section, having an integrated time scale across the Early-Middle Triassic boundary, is a potential international GSSP reference section for simultaneously defining and dating the Early-Middle Triassic boundary and the base of the Anisian Stage.

Amazingly, one may observe that the Wantou section illustrated by Chen Y et al. (2020, fig. 3) lacks any chronostratigraphic calibration, and also one may observe the reversed hierarchy of the biotic and physical proxies in defining a chronostratigraphic boundary in the standard Triassic timescale that is basically built on ammonoid biochronology.

\section{Lithology}

The Wantou section, about $17 \mathrm{~m}$ thick, as reported by Chen Y et al. (2020), consists of three lithostratigraphic units, as follows:

- The Unit V of the Loulou Formation (Bed 1 to $15)$, at the base of the section, made up of thickbedded limestone with abundant bioclasts, around $9.60 \mathrm{~m}$ thick, from which nearly $3.00 \mathrm{~m}$ of strata are a package of volcaniclastic sandstone, the so-called Green-bean Rock (Bed 9);

- The Transition beds (Bed 16 to 22), made up of thin-bedded, siliceous mudstone containing calcareous nodules, nearly $3.20 \mathrm{~m}$ thick;

- The Baifeng Formation, at the top of section, made up of laminated shales (Bed 23) with occasional beds of limestone and volcanic ash, around $4.50 \mathrm{~m}$ thick.

\section{Ammonoid record}

According to Chen Y et al. (2020), in the stratigraphic interval that encompasses the Early-Middle Triassic boundary, only two ammonoid assemblages have been identified by Galfetti et al. (2008) in the Wantou section, as follows:

- The Neopopanoceras haugi ammonoid assemblage, in the stratigraphic interval of Bed 6 to 14, bracketing the Bed 9 of the Green-bean Rock;

- A barren stratigraphic interval for ammonoid occurrences, around $5.60 \mathrm{~m}$ thick;

- The Platycuccoceras Beds, located inside the Baifeng Formation from meter 14 to the top of the section. 


\section{Conodont record}

According to Chen Y et al. (2020), in the stratigraphic interval that intersects the Early-Middle Triassic boundary, several main conodont events are reported in the Wantou section, as follows:

- FO (first occurrence) of Gladigondolella carinata, base of Bed 14, below the top of the Neopopanoceras haugi ammonoid assemblage;

- FO (first occurrence) of Chiosella timorensis s.s., inside of Bed 15, approximately $1.3 \mathrm{~m}$ above the top of the Neopopanoceras haugi ammonoid assemblage;

- FO (first occurrence) of Gladigondolella tethydis, at the base of Bed 20, in the interval barren of ammonoids in the Transition beds.

\section{Comments}

The stratigraphic interval of the Early-Middle Triassic boundary (EMTB) in the Wantou section, as inferred by Chen Y et al. (2020), only 5.80 thick, from Bed 14 till Bed 23, has three different lithologies, i.e., the shallowwater carbonates of the Loulou Formation, the deepwater mudstones of the Transition Beds and the deepwater siliciclastic turbidites of the Baifeng Formation. The Unit $\mathrm{V}$ at the top of the Loulou Formation is intercalated, between Bed 9 and Bed 11, by the Green-bean Rock, a volcanic tuff around $3.00 \mathrm{~m}$ thick. So, this close association of three contrasting lithologies does not meet the ICS requirement according to which a GSSP must be defined in a rock succession having an uniform lithology, allowing a continuity of the biotic environmental conditions and thus ensuring a continuous biotic record.

The unstable environmental conditions in the Wantou section, as reflected by the rapid lithological changes, implying major ecosystem changes, are closely illustrated by the incomplete ammonoid record in this section. Even the authors recognize that owing to a transitional environmental and ecosystem change in the two "exceptional" Chinese section "there is not a pronounced simultaneous biostratigraphic transition in both ammonoids and conodonts to conveniently mark the boundary between the Early and the Middle Triassic" (Chen Y et al., 2020, p. 12). The Neopopanoceras haugi ammonoid assemblage occurs in a stratigraphic interval of about $4.80 \mathrm{~m}$ thick, from Bed 6 to mid of Bed14, in which nearly $3.00 \mathrm{~m}$ is represented by the Bed 9 of the Green-bean Rock. The HO (highest occurrence) of the Neopopanoceras haugi ammonoid fauna is located at meter 8.00 inside the Bed 14 in the upper part of the Loulou Formation. After an interval barren for ammonoid occurrence, around $5.60 \mathrm{~m}$ thick, including the Transition Beds and the lower half of the Beifeng Formation, the next ammonoid occurrence is represented by the Platycuccoceras beds, starting from meter 14.00 inside the lower half of the Beifeng Formation.

From the above data on the ammonoid record in the Wantou section, the following observations are prompted: there are no conclusive data regarding the LAD (last-appearance datum) of the latest Spathian Neopopanoceras haugi ammonoid fauna, which is bracketing the Green-bean Rock;

- the HO (highest occurrence) of the latest Spathian Neopopanoceras haugi ammonoid fauna in the Wantou section doesn't imply it represents the top of the uppermost Spathian Haugi ammonoid biozone in this section;

between the latest Spathian Neopopanoceras haugi beds and the middle Anisian Platycuccoceras beds there is an extended chronostratigraphic interval for which ammonoid data are completely missing in the Wantou section;

- there is no ammonoid evidence for the Courtilloticeras stevensi ammonoid biozone, the highest ammonoid biozone of the latest Spathian following the Neopopanoceras haugi ammonoid biozone, as documented in northwestern Nevada;

- there are no ammonoid data for the lower Anisian, on which the base of the Middle Triassic could be fixed in the Wantou section;

- $\quad$ the first occurrence (FO) age of Ch. timorensis level, which is placed at $1.3 \mathrm{~m}$ above the last occurrence of Neopopanoceras haugi and considered to be a potential proxy for assigning the EMTB, is not properly documented, as even the EMTB age in the Chinese sections is not properly documented by ammonoid biochronology.

As can be seen, Chen Y et al. (2020) do not provide any ammonoid record just for the interval around the EarlyMiddle Triassic boundary, which is critical to place this boundary.

Amazingly, in opposition to Chen Y et al. (2020), who placed the level of FO-C.t. in the Bed 15, well above the top of the Green-bean Rock, very recently Li D et al. (2021) reported, however, that in the Yongning section, South China, the Early-Middle Triassic boundary is placed at the first occurrence (FO) of conodont Chiosella timorensis that is located $\sim 40 \mathrm{~m}$ below the Green-bean Rock. These contradictory data, with regard to the placement of FO-C. $t$. level versus the Green-bean Rock, raise serious doubts as regards the coincidence between the first appearance datum (FAD) versus the lowest occurrence (LO), i. e., the coincidence of its earliest biochronological event with its lowest biostratigraphicum datum, and the real chronostratigraphic range of the conodont Chiosella timorensis in the Chinese sections.

As Hugo Bucher underlined in his Comment in a Forum hosted by the Research Gate platform (Ogg et al., 2020a) there is no room to find other ammonoid faunas in the interval between Bed 14, having the $\mathrm{HO}$ of the late Spathian Neopopanoceras haugi ammonoid fauna, and Bed 23 that contains the middle Anisian Platycuccoceras fauna.

With regard to the conodont events in the Wantou section, Chen Y et al. (2020) used the FO of Chiosella timorensis sensu stricto (Ch. timorensis s.s.) as the proxy 
for the EMTB, although they admitted there is a debate "whether its FO would be a suitable synchronous global marker and might conflict with traditionalbased recognition of the basal Anisian".

Although Chen Y et al. (2020, p. 4) know well that the conodont $C h$. timorensis has been recorded in northwestern Nevada by Goudemand et al. (2012) together with the late Spathian ammonoid fauna of the Neopopanoceras haugi Zone, these authors minimize the Nevada ammonoid/conodont data and even trivialize them as coming from a float sample. Moreover, the authors asserted that, depending upon the preference for either an ammonoidor conodont-based biostratigraphic definition for the base of Anisian, it requires either that the LO of the conodont Ch. timorensis begins in the latest Spathian, or else the uppermost portion of the Neopopanoceras haugi ammonoid zone straddles the boundary between the Spathian and the Anisian as suggested by Orchard (2016, p. 30).

It must be underlined in northwest Neavada the Neopopanoceras haugi ammonoid biozone, the penultimate ammonoid biozone in the latest Spathian, is overlain by the Courtilloticeras stevensi ammonoid biozone (Monnet et al., 2013, fig. 2), both ammonoid biozones, grouped collectively in the latest Spathian Haugi Zone by Guex et al. (2010, fig. 13), being equivalent to the high-latitude latest Spathian Keyserlingites subrobustus ammonoid biozone in British Columbia (see Tozer, 1994a; Monnet \& Bucher, 2006, fig. 6). If adopting the assertion of Chen Y et al. (2020), it means that the two ammonoid biozones of the upper Spathian should be moved at the base of the Anisian. If this will happen, only to the desire to save the "reputation" of the conodont Chiosella timorensis as a biotic proxy for the EMTB, it would be a major violation of the standard Triassic timescale, which is primarily built on the ammonoid biochronology (see Ogg et al., 2020b, figs. 25.5 to 25.7 ).

Lastly, one must emphasize that the taxonomic interpretation of Ch. timorensis by Chen Y et al. (2020) is opposite to the interpretation of Goudemand et al. (2012). Chen Y et al. (2020) use the term Ch. timorensis sensu lato (Ch. timorensis s.l.) for the specimens included under the expanded taxonomy of Goudemand et al. (2012) and the term Ch. timorensis sensu stricto (Ch. timorensis s.s.) for the more restricted definition as used by Yan et al. (2015).

In spite of the major shorthcomings implying rapid lithological changes and the incomplete ammonoid record in the Wantou section, Chen Y et al. (2020) claimed that the Wantou section is unique across the EMTB interval in its combination of conodont-rich strata, ammonoids, magneto- and chemostratigraphy, and other physical events. However, the authors recognize there is not a pronounced simultaneous biostratigraphic transition in both ammonoids and conodonts to conveniently mark the boundary between the Early and the Middle Triassic. All these fully explain why the "exceptional" Wantou section, illustrated by Ogg (2019) and Chen Y et al. (2020), lacks any chronostratigraphic calibration and why the Early-Middle Triassic boundary is not properly illustrated. In fact, the article of Chen Y et al. (2020) is mostly focused, as is evident from its title, on the Early-Middle Triassic boundary interval, and not to indicate properly the boundary in the Wantou section. The missing chronostratigraphic calibration does not justify in any way the qualification of the "exceptional" Wantou section as being a potential international GSSP reference for the base of the Anisian Stage.

With regard to the volcanic ashes of the so-called 'Greenbean Rock' (GBR) occurring around the OlenekianAnisian boundary (OAB) in the Yangtze platform and Nanpanjiang basin, South China, a zircon U-Pb age of $247.49 \pm 0.68 \mathrm{Ma}$ has recently been advanced by Feng et al. (2021), and this is considered to be in agreement with the OAB U-Pb ages of $247.28 \pm 0.12 \mathrm{Ma}$ indicated by Lehrmann et al. (2006, 2015b) for the Gunadao section, and of $247.305 \pm 0.040 \mathrm{Ma}$ indicated by Ovtcharova (2015) for the Wantou (= Jinya) section. Feng et al. (2021) concluded the GBR in the western margin of the Yangtze platform may serve as the "marker" for the OAB and can be used in regional stratigraphic correlation. On the contrary, Li D et al. (2021) assumed, however, an astronomically tuned time scale of $246.6+0.3 /-1.4 \mathrm{Ma}$ for the GBR, whilst the astronomically tuned FO of $C h$. timorensis, which is located $\sim 40 \mathrm{~m}$ below at Yongning section, occurs at $246.8 \pm 0.1 \mathrm{Ma}$. Thus, the geochronological dating of the FO of Ch. timorensis in the Chinese sections is controversial.

It must be underlined that in all Chinese sections the conodont Chiosella timorensis is used as a primary proxy for the OAB. Fatefully, the physical events registered in the Wantou section, like magneto- and chemostratigraphy, and also the U-Pb ages, are all discussed and closely tied to the FO of the conodont Chiosella timorensis, which as shown in the present paper is a defunct proxy for the $\mathrm{OAB}$.

In conclusion, the Wantou section lacks a suitable ammonoid/conodont biochronology to be accepted as a reference section for the Early-Middle Triassic boundary.

A chronostratigraphic calibration of the "exceptional" Wantou section, based on the ammonoid and conodont biostratigraphic data in Chen Y et al. (2020, fig. 3) and also the most probable placement of the Early-Middle Triassic boundary are here suggested in Fig. 2. In the absence of ammonoids, and only based on the FO of Gladigondolella tethydis that is currently reported in the lower Anisian (see Orchard et al., 2007b, 2010; Goudemand et al., 2012; Chen Y-L et al., 2016; Golding, 2021), the Olenekian-Anisian boundary is presumably placed here at the base of Bed 20 in the Wantou section. 


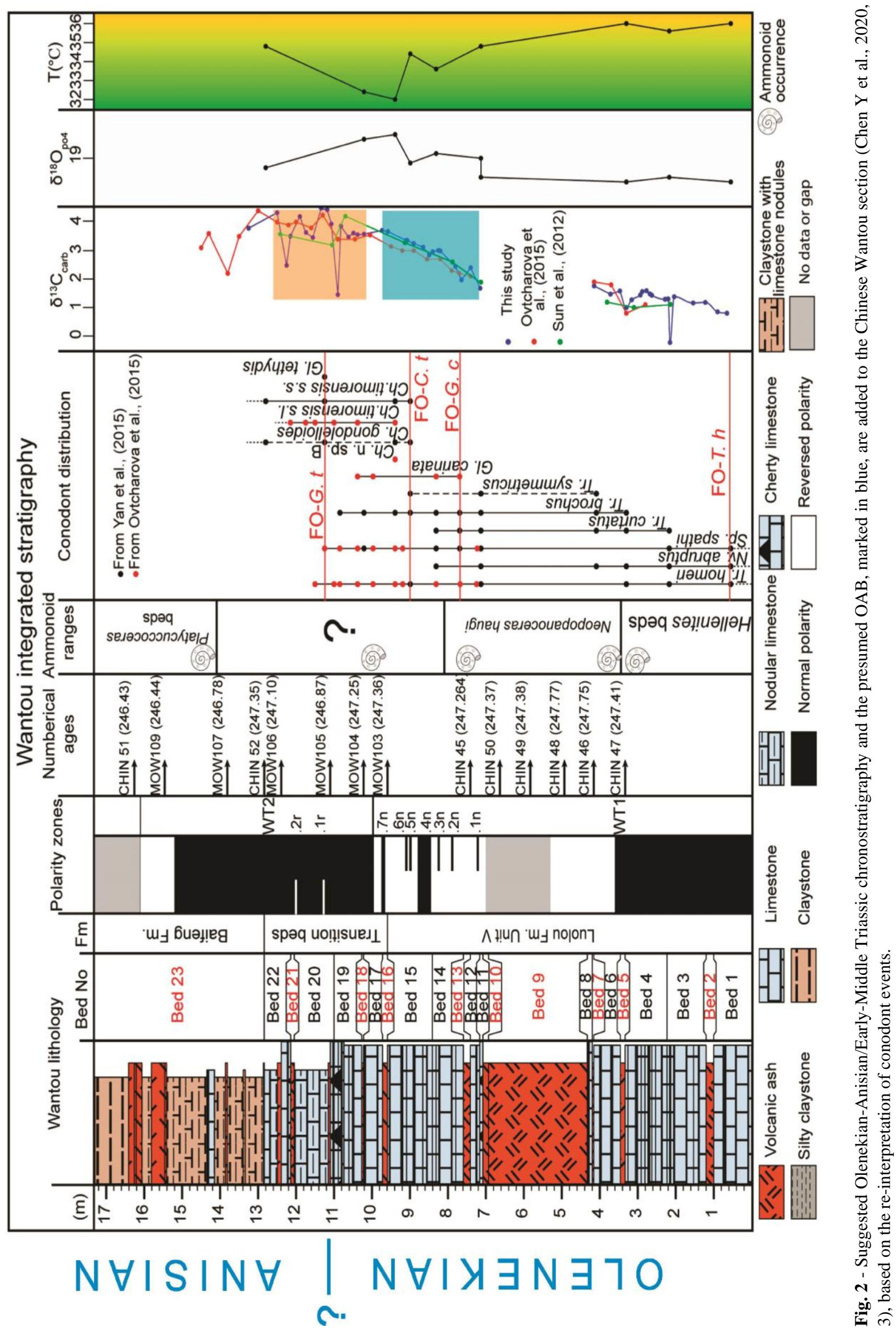


THE CONODONT Chiosella timorensis, A DEFUNCT PRIMARY BIOTIC PROXY FOR THE BASE OF THE ANISIAN STAGE/MIDDLE TRIASSIC SERIES

The base of the Anisian Stage versus the FO of Chiosella timorensis, historical premises

As is already well known, following the remarkable studies done on the Triassic successions from the eastern Mediterranean region, on the Chios Island (Greece) and the Kokaeli Peninsula (Turkey), Assereto (1974) replaced the "Hydaspian" interval from the old chronostratigraphic scheme of the Triassic System of Mojsisovics et al. (1895), subsequently classed as Lower Anisian (see Arthaber, 1906; Pia, 1930; Rosenberg, 1952, 1959; Bender, 1970a; Zapfe, 1974, 1983; Budurov, 1976 a, b), by the Aegean and Bithynian substages. These new Anisian substages have been added to the Pelsonian and the Illyrian substages introduced by Pia (1930), which replaced the "Balatonisch" and "Bosnisch" substages, respectively, in the primary "Anisisch" of Mojsisovics et al. (1895). The historical development with regard to the scope of the actual standard Anisian Stage/lower Middle Triassic has been summarized in a comprehensive table by Assereto (1974, fig.7). By correlation with the North American Triassic chronostratigraphy introduced by Silberling \& Tozer (1968) and Tozer (1971, 1974), the Aegean Substage is correlative with the Lower Anisian, the Bithynian and the Pelsonian substages are correlative with the Middle Anisian, and the Illyrian Substage is correlative to the Upper Anisian, respectively (see also Zapfe, 1983; Mietto \& Manfrin, 1995; Shevyrev, 1995, 1996). This chronostratigraphic correlation is currently adopted by the International Commission of Stratigraphy in the standard Triassic Time Scale (see Gradstein et al., 2004, 2012, 2020). As regards the chronostratigraphic continuity of the stratigraphic succession from the Lower Triassic to the Middle Triassic, it is well documented by the ammonoid biostratigraphy in Nevada and British Columbia, and also in the Arctic regions of Canada, Svalbard and Russia (Silberling \& Tozer, 1968; Tozer, 1967, 1978, 1994a; Dagys, 1988, 1994; Dagys \& Tozer, 1989; Weitschat \& Dagys, 1989; Dagys \& Weitschat, 1993; Dagys \& Sobolev, 1995; Bucher, 1989; Monnet \& Bucher, 2006; Guex et al., 2010). Instead, in the classical locality of the primary "Anisisch" of Mojsisovics et al. (1895) in the Northern Calcareous Alps, the lower part of the standard Anisian Stage (Summesberger \& Wagner, 1972; Zapfe, 1974) is devoid of ammonoid faunas representative for the Aegean and Bithynian substages as defined by Assereto (1974), and, consequently, the transition from the Lower Triassic to the Middle Triassic is not documented by ammonoid biostratigraphy in the classical locality. Also, in the Eastern Mediterranean region, where the Aegean Substage was introduced by Assereto (1974), the transitional interval from the middle Spathian ammonoid fauna described by Renz \& Renz (1948) and Mertmann \& Jacobshagen
(2003) to the base Anisian ammonoid fauna, as described or reported by Bender (1970a), Jacobshagen \& Tietze (1974), Assereto et al. (1980), Fantini Sestini (1981), Gaetani et al. (1992) and Jacobshagen et al. (1993), is devoid of chronostratigraphically significant ammonoids to demonstrate a continuous transition from the Spathian/upper Olenekian/Lower Triassic to the Aegean/lower Anisian/Middle Triassic. The ammonoid biozones identified in the western USA for the higher part of the Spathian (Guex et al., 2010), i.e., the penultimate Neopopanoceras haugi ammonoid biozone and the ultimate Courtilloticeras stevensi ammonoid biozone, are not represented in the ammonoid record of Chios Island, the type locality designated by Assereto (1974) for the Aegean Substage, and by Assereto et al. (1980), Gaetani et al. (1992) and Jacobshagen et al. (1993) as the favoured GSSP for the Olenekian-Anisian boundary.

When Assereto (1974) introduced the Aegean Substage, he provisionally defined its lower boundary at the base of the Paracrochordiceras-Japonites beds, but he also suggested placing into the Aegean the apparently unfossiliferous beds that lie between the beds with the Spathian Subcolumbites ammonoid fauna and the Paracrochordiceras-Japonites fauna. It is just the stratigraphic interval in which Assereto et al. (1980) subsequently mentioned finding of an unusual ammonoid assemblage of some upper Scythian ammonoids, including Eophyllites dieneri Arthaber and Procarnites kokeni Arthaber, besides cladiscitids of presumed Anisian age, in which the FAD of Neogondolella timorensis had been placed by Nicora (1977) and Assereto et al. (1980). Taking into account the co-occurrence of the cladiscitids, having an as yet unclear chronostratigraphic position at that time, with the first occurrence of Neogondolella timorensis, Assereto et al. (1980, p. 731) preferred to interpret that the beginning of the Anisian is marked by the first appearance of cladiscitids, and that this would also coincide with the first occurrence of $N$. timorensis. Accordingly, Assereto et al. (1980) claimed "this proposal involves that the Haugi Zone and the equivalent Subrobustus Zone must also be considered to be of lowermost Anisian age". However, the authors concluded that "A more complete definition of the Aegean substage in terms of the ammnoids and conodonts cannot be based only on the present study". In line with the above assertion, Fantini Sestini (1981), when publishing the Aegean (Lower Anisian) ammonoids from Chios, further emphasized "if the beginning of the Anisian is marked by the first appearance of cladiscitids and of $G$. timorensis, the Haugi Zone and its equivalent Subrobustus Zone (Silberling \& Tozer, 1968) must be dated as earliest Anisian (Early Aegean) and not as latest Spathian".

Gaetani et al. (1992, p. 197), although they stressed a failure in the continuity of the ammonoid documentation in the Chios section, causing an incomplete picture of the underlying latest Lower Triassic biostratigraphy, proposed that the Aegeiceras/Japonites FAD should represent the base of the Anisian. In such a case, Gaetani et al. 
(1992) pointed out that the conodont Gondolella timorensis (= Chiosella timorensis), which appears before the appearance of the first Anisian ammonoid fauna, cannot be used to define the base of the stage exactly, because its appearance approximates the beginning of the Anisian only in a broad sense. Accordingly, Gaetani et al. (1992, p.195) inferred that the coexistence of Neospathodus homeri and Gondolella timorensis seems to characterize the latest Spathian, while the occurrence of $G$. timorensis alone could strictly approach the beginning of the Aegean. Finally, Gaetani et al. (1992), although they stated that the $G$. timorensis FAD cannot be used to define the beginning of the Anisian if prominent value is given to ammonoids, stressed that only a change in conventions, giving more weight to the conodont tool in the case of the nonperfect coincidence of relevant conodont and ammonoid FADs, would shift the position and hence the definition of the lower boundary of the Anisian to the FAD of G. timorensis, as had been suggested by Assereto et al. (1980).

Jacobshagen et al. (1993) re-evaluated the Chios section and advocated further to define the Scythian-Anisian boundary on Chios Island with the first appearance of the Japonites-Aegeiceras ammonoid fauna or, if ammonoids are missing, above the homeri/timorensis conodont assemblage. The above mentioned authors firmly stated that "the first appearance of $G$. timorensis is a little below the first Anisian ammonoids, together with Scythian ones". As regards the presumed Anisian cladiscitid ammonoids mentioned by Assereto et al. (1980, p. 725), which were found at Chios in association with typical Scythian ammonoids, such as Procarnites kokeni, Pseudosageceras albanicum and Eophyllites arthaberi, Jacobshagen et al. (1993) inferred it is presumably due to condensation. Although in the Chios section there are clear evidence of stratigraphic condensation, however, the occurrence of cladiscitids in close association with Spathian ammonoids is now clearly demonstrated by the new ammonoid data obtained in the section of Deşli Caira, Romania (Grădinaru, new data). Concerning the proposal of Assereto et al. (1980) that the appearance of Neogondolella timorensis indicates the beginning of the Anisian and this implies that the Neopopanoceras haugi zone would be included in the Anisian, Jacobshagen et al. (1993) did not agree with this proposal, and based on their new findings the authors stated "it seems also possible to assume that this conodont species had its first appearance already in the upper Spathian", and that "the conodont argument of Assereto et al. (1980) would not be urgent".

Later, Muttoni et al. (1994, p.41) stated that "For historical reasons, in Triassic stratigraphy an ammonoidbased boundary is preferred to a conodont-based boundary, if the two are not coincident". Amazingly, the authors concluded, however, that in the Chios section the Anisian starts at the first occurrence of G. timorensis, this being coincident with a paleomagnetic polarity reversal, although, as the authors stressed, the FO of $G$. timorensis is well below the occurrence of the Anisian ammonoid assemblage in the Chios section (see fig. 2 in Muttoni et al., 1994). In spite of the above statement, according to which in the Triassic stratigraphy an ammonoid-based boundary is preferred to a conodont-based boundary, Muttoni et al. (1995, 1996, 1998, 2019) obsessively continued furthermore to pay credit to the conodont biostratigraphy and to its concurrent magnetostratigraphy in discussing the Early-Middle Triassic chronostratigraphy.

This saga of the conodont Chiosella timorensis fully underlines the uncertainities regarding the chronostratigraphic position of the FAD of this conodont in the Chios section, which was promoted as the type locality of the Aegean by Assereto (1974), Assereto et al. (1980), Gaetani et al. (1992) and Jacobshagen et al. (1993).

As seen from the data published by Bender (1970a), Jacobshagen \& Tietze (1974), Assereto et al. (1980), Gaetani et al. (1992), Jacobshagen et al. (1993) and Mertmann \& Jacobshagen (2003), in the Chios section there are no ammonoids to demonstrate the presence of the latest Spathian ammonoid biozones as defined in the western United States by Guex et al. (2010). Bucher (1989) stated that the Paracrochordiceras-JaponitesAegeiceras ammonoid association at Chios published by Fantini Sestini (1981) remains unravelled within the Lower Anisian Substage, as compared with the ammonoid biochronology in Nevada. Subsequently, Jacobshagen et al. (1993) suggested to correlate the AegeicerasJaponites beds of Chios with the lowermost Anisian Japonites welteri beds of Nevada.

It is just this incomplete ammonoid record around the Olenekian-Anisian/Early-Middle Triassic boundary in the Chios section, supporting untenable assertions with regard to the boundary, upon which for several decades the conodont workers have based their option to use the conodont Chiosella timorensis as a primary biotic proxy for the as yet unresolved Olenekian-Anisian boundary in the type locality of the Aegean Substage. One may conclude that in the Chios section the upper part of the Spathian is either condensed or, more probably, it still remains underexplored for ammonoids.

\section{Chiosella timorensis, a conodont having a highly con- troversial taxonomy and definition}

With regard to the definition of the conodont species Chiosella timorensis, for a long time the conodont researchers adopted a broader concept, with Spathognathodus gondolelloides Bender, 1970 in the synonymy of Gondolella timorensis Nogami, 1968, the first being interpreted as a juvenile of the latter (e.g., Sweet, 1970a, 1973; Kozur, 1973b; McTavish, 1973; Mirăuţă, 1974; Kemper et al., 1976; Buryi, 1979, 1989; Assereto et al., 1980; Chhabra \& Sahni, 1981; Matsuda, 1983; Gaetani et al., 1992; Klets, 1995; Kiliç, 2021). 
However, Budurov (1976b), Buryi (1979, 1989), Buryi et al. (1980), Budurov et al. (1983, 1985, 1987, 1988a, 1989) and Budurov \& Trifonova (1991) considered that Neospathodus gondolelloides is a senior synonym of Chiosella timorensis. The above-cited authors based their conclusion by only commenting on the disputed dates when the monographs by Nogami (1968) and Bender (1970b) were published, instead of properly addressing the distinct morphologies of the two conodont species.

Later, Kozur (1989b) and Orchard (1995) stated that gondolelloides is a distinct conodont species, and thus not a juvenile synonym of timorensis, and also that it begins earlier than the latter species, in the upper Spathian, and that the two species co-occur in the Aegean. This has been further agreed on by Kozur et al. (1995), Budurov \& Sudar (1995), Orchard (1995), Meço (1999, 2010), Kozur (2003a, b), Krystyn et al. (2004), Kozur \& Bachmann (2005), Ovtcharova et al. (2006), Orchard et al. (2007 a, b), Klets (2008), Orchard (2010) and Goudemand et al. (2012).

Even the generic assignement of the conodont species timorensis has been variously interpreted over time, as Gondolella (Nogami, 1968; Kozur, 1973b, 1980a-b; Gaetani et al., 1992; Jacobshagen et al., 1993), Paragondolella ? (Koike et al., 1971), Neospathodus (Sweet, 1970a, 1973; McTavish, 1973; Kemper et al., 1976; Goel, 1977; Ishida, 1979; Koike, 1979a-b; Watanabe et al., 1979; Buryi, 1979, 1989; Tanaka, 1980; Wang Z-H, 1982; Matsuda, 1983; Dagys, 1984; Klets, 1995), Neogondollela (Nicora, 1977; Collinson \& Hasenmueller, 1978; Assereto et al., 1980; Koike, 1981; Sweet \& Bergström, 1986; Paull, 1988; Paull \& Paull, 1998), Kashmirella (Budurov et al., 1988b, 1989; Budurov \& Trifonova, 1991, 1995; Budurov \& Sudar, 1995; Kiliç et al., 2016), or Chiosella (Kozur, 1989b, 1999, 2003a-b; Orchard \& Bucher, 1992; Orchard, 1992, 1994a, 1995, 2005, 2010; Koike, 1999; Klets, 2006, 2008; Goudemand et al., 2012; Plasencia et al., 2013; Yan et al., 2015; Chen Y-L et al., 2016; Muto et al., 2019, 2020; Chen Y et al., 2020).

The generic assignement of the species gondolelloides has also been interpreted either as Spathognathodus (Bender, 1970), Neospathodus (Sweet, 1970a, 1973; Orchard, 1995), Gondolella (Kozur, 1973b; Gaetani et al., 1992), Kashmirella (Budurov et al., 1988b, 1989; Budurov \& Trifonova, 1991, 1995; Budurov \& Sudar, 1995; Kiliç et al., 2016) or Chiosella (Kozur, 1989b; Orchard \& Bucher, 1992). More recently, the assignement of the species gondolelloides was limited to Chiosella (e.g., Klets, 2008; Orchard, 2010; Plasencia et al., 2013; Muto et al., 2019).

Furthermore, Nicora (1977), Kozur (1989b) and Gaetani et al. (1992) treated Neogondolella aegaea Bender, 1970 as a junior synonym of Chiosella timorensis, thus implying the equivalence between the Timorensis Zone of Sweet (1970a), placed in the top of the Spathian, with "Die aegaea - Zone" of Bender (1970b), placed in the Anisian. Lastly, the two morphotypes of timorensis that were discrimated by Nicora, Neogondolella timorensis timorensis (Nogami, 1968) and Neogondolella timorensis benderi Nicora, 1977, respectively, together with Spathognathodus gondolelloides Bender, 1970, interpreted as a juvenile of timorensis, are all allocated to Godolella timorensis by Gaetani et al. (1992, p. 195, pl. 17), thus complicating once again the definition of this conodont species.

As seen from the above references, the definition of timorensis versus gondolelloides, in which aegaea was also involved, represented a long disputed issue, and it remains still unresolved, being mostly a problem of subjective criteria agreed by the conodont researchers.

During the Triassic Symposium held at St Christina/Val Gardena, Italy, September 2003, an ad-hoc group meeting including Heinz Kozur, Mike Orchard, Alda Nicora, Leopold Krystyn and Eugen Grădinaru examined the conodont material from the Deşli Caira section, in Romania, and concluded that gondolelloides and timorensis are distinct species of Chiosella, the timorensis species having a narrow platform that surrounds the posterior end of the carina. It was also concluded based on the ammonoid data at hand at that time in the Deşli Caira section that Ch. gondolelloides is common in the uppermost Spathian, whereas Ch. timorensis began later, at the base of the Aegeiceras ugra fauna. This conclusion was adopted by Grădinaru et al. (2006, 2007) and Orchard et al. (2007a) for the Deşli Caira section, and closely mimicked by Orchard et al. (2007b) and Lehrmann et al. (2006, 2015a-b) for the Guandao section in China.

Discussing this matter, Golding (2021a) underlies that recently "Additional issues with $\boldsymbol{C h}$. timorensis center on the definition of the species, and its differentiation from related species such as $C h$. gondolelloides, $C h$. n. sp. A and Ch. n. sp. B (see discussion in Goudemand et al., 2012)", whereas "At Wantou Chen et al. (2020) recognized the new species of Chiosella identified by Goudemand et al. (2012), but retained the name $\boldsymbol{C h}$. gondolelloides for several specimens considered to be Ch. timorensis by Goudemand et al. (2012), making correlation of the Chiosella faunas between Wantou, Deşli Caira and Guandao difficult at this time".

Lastly, besides the controversial definitions of the two leading species of the conodont Chiosella, the lineage gondolelloides-timorensis has also been for a long time interpreted variously. Early initiated by Sweet (1970a), Kozur (1973b, 1989b, 2003b), Kozur et al. (1995) and Budurov (1976b), this remained along-disputed issue, being even actually controversially discussed by Orchard (1995), Goudemand et al. (2012), Yan et al. (2015), Chen Y-L et al. (2016), Chen Y et al. (2020) and Kiliç et al. (2016).

Thus, one may conclude that the conodont species Chiosella timorensis for a long time had a disputed taxonomic status and also very unstable morphological definitions, and these remain still unresolved. For sure, the issue of the conodont species Chiosella timorensis was and still is one of the most controversial among the Triassic 
conodonts as regards its definition and taxonomic assignement. All these aspects cast major and reasonable doubts about the reliability of this conodont species as a potential primary biotic proxy for the OlenekianAnisian/Early-Middle Triassic boundary.

Chiosella timorensis, a conodont having a longdisputed first occurrence and chronostratigraphic range

The first occurrence (FO), implying the distinction or coincidence between the first appearance datum (FAD) versus the lowest occurrence (LO), and the chronostratigraphic range of the conodont Chiosella timorensis have been a long-disputed issue for the Triassic conodont researchers. On the other side, with regard to the coincidence of the LO and the FAD of the conodont $C h$. timorensis, i.e., the coincidence of its lowest biostratigraphicum datum with its earliest biochronological event, in almost all cases this was not properly tied to the ammonoid bio-chronostratigraphy.

When Nogami (1968, p.117) described from the Portuguese Timor the new conodont species Gondolella timorensis, from the beginning an uncertainity with regard to the dating of its occurrence was raised. Although this species was found in "dunkelgrauerer Kalk mit vielen Ammoniten sowie Leiophyllites timorensis Bando, L. sp. und Procarnites aff. kokeni (Arthaber)", its occurrence was dated by Nogami (1968, p.128) as "oberstes Skyth (oder unterstes Anis)". This is at odds with the qualified opinion of Nakazawa \& Bando (1968, p. 87), who stated that "Judging from the ammonites, the age of the limestone refers to the Latest Skythian, rather than the Early Anisian". Unfortunately, in spite of the expert dating done by Nakazawa \& Bando (1968), many of the Triassic conodont researchers gave credit to the uncertain dating advanced by Nogami (1968), and by this all subsequent discussions regarding the age of the first occurrence of the conodont species Chiosella timorensis were placed on a uncertain, long-disputed path.

Chronologically, the next reference to Gondolella timorensis Nogami, 1968 was by Sweet (1970a), who described this conodont species as Neospathodus timorensis (Nogami, 1968) from the Narmia Member of Mianwali Formation at Narmia, in West Pakistan. Sweet (1970a, p.217) nominated for the first time this conodont species "as the index for a distinctive, if poorly known, Zone of Neospathodus timorensis". Sweet (1970a) further stated that "An Anisian age is suggested (but by no means established) by noting that conodonts from Anisian (= "Hydaspian") rocks on Chios, Greece, that Bender (1967?) named Spathognathodus gondolelloides are probably closely related to the ones herein referred to $N$. timorensis", and "If this is so, and Nogami's uncertainity as to the age of the rocks yielding the types of $N$. timorensis is well founded, it may be that the uppermost bed of the Narmia (and the Zone of $N$. timorensis) are Anisian in age".

Subsequently, Sweet et al. (1971, fig. 1) errected 22 Triassic conodont zones tied to the Triassic ammonoid zones, with Zone 13 (Neospathodus timorensis Zone) being placed at the top of the Spathian Substage.

Clark (1977), Clark et al. (1979), Solien (1979), Paull (1988), and other authors, closely adopted the conodont zonation of Sweet et al. (1971).

Contradictory data to the first occurrence of timorensis have been provided by Nicora (1977) and Collinson \& Hasenmueller (1978). Nicora (1977, p. 97) concluded in her well-known monograph on the Lower Anisian platform-conodonts from the Tethys and Nevada that "data from Chios and Nevada suggest that $N$. $t$. timorensis makes its appearance at the base of the Anisian and characterizes the lower part of the Aegean Substage of Asssereto (1974)". This statement of Nicora (1977) was based on a re-interpretation, which remains, however, disputable in view of the previous chronostratigraphic interpretation made by Nakazawa \& Bando (1968) of the taxonomic assignement of the ammonoids mentioned by Nogami (1968) at the type locality of Gondolella timorensis. Consequently, Nicora (1977, p. 97) stated that "it is possible to say that $N$. $t$. timorensis, in the type locality, represents an uncertain interval between the Upper Scythian and Lowermost Anisian". Nicora (1977, p. 97) also stated that "the biostratigraphic position of $N$. t. timorensis in West Pakistan is uncertain", but concluded that "it occurs there above rocks that yielded Upper Scythian ammonoids". Ultimately, Nicora (1977, p. 97) based her assertion on finds in the Star Canyon and Coyote-Bloody Canyon sections of Nevada, where the author mentioned that $N$. $t$. timorensis occurs with Lower Anisian ammonoids, and also on the interpretation of ammonoid-conodont associations in Chios, stating that it "is the only place in which it is possible to fix the biostratigraphic level of first occurrence of $N$. $t$. timorensis".

On the contrary, Collinson \& Hasenmueller (1978, p. 187) reported Neospathodus homeri and Neospathodus timorensis in samples from the Haugi ammonoid zone in Nevada, which Silberling \& Tozer (1968) regarded as highest Spathian. Anticipating these controversial findings by Nicora (1977) and Collinson \& Hasenmueller (1978), we must mention that Orchard \& Bucher (1992) and Orchard (1994a) stated that Chiosella timorensis is unconfirmed at the level of the latest Spathian Haugi Zone (Yatesi beds) in Nevada, in which Orchard (1994a, p.108) found that conodont faunas are dominated by $N$. ex gr. homeri, with some elements approaching Chiosella gondolelloides (Bender). This controversy is now finally resolved by the undisputed find of Chiosella timorensis in the latest Spathian Haugi ammonoid zone in Nevada (Goudemand et al., 2012).

Sweet \& Bergström (1986, p.108 and fig. 9), although they have contended that "the Timorensis Zone may span the Scythian-Anisian boundary", stated, however, 
that "this boundary is drawn at the base of the Timorensis Zone, but with no particular conviction". Finally, Sweet (1988, p. 269 and p. 271) gave credit to the statements given by Nicora (1977) and by this overcame his non-conviction, and concluded that "The Timorensis Zone is regarded as Anisian (Aegean), and it is suggested that the base of this zone closely approximates the Spathian/Anisian boundary and may be used regionally to mark the boundary between the Lower and Middle Triassic".

Later, Sweet's statement that "the positions in Pakistani sections of common late Spathian ammonoids project to levels in the Composite Standard (CS) just below the first occurrence of Neospathodus [or Neogondolella] timorensis" has not been supported by the ammonoid succesion provided by Guex (1978, fig. 4), as the topmost interval of the Spathian Substage in the Salt Range, Pakistan, corresponding to the Haugi ammonoid zone in Nevada, is not documented by ammonoids.

Chronologically, Nicora (1977) and Assereto et al. (1980) made for the first time the formal proposal that the FO of the conodont Gondolella timorensis Nogami, 1968 may be used for the definition of the lower boundary of the Anisian Stage in a clearly named section and locality, i.e., the section at Chios, Greece. The historical premises on which these authors prompted their proposal are unfolded in a foregoing section in the present paper where it is outlined that the Chios section lacks conclusive ammonoid data to properly fix the Spathian-Aegean/OlenekianAnisian boundary.

Besides the above mentioned references that historically are the most relevant for the issue discussed in the present section, there are many other references in which the first occurrence of Chiosella timorensis and its chronostratigraphic range have been discussed for a long time, which are also highly controversial. One relevant reference, which demonstrates the still existing uncertainity around the above discussed issue by the end of the 1980s, is Lozovsky et al. (1989), who stated that Neospathodus timorensis Zone appers to be early Anisian, but the lower part of its range may slightly correlate with the uppermost Lower Triassic.

The issue of first occurrence and chronostratigraphic range of the timorensis/gondolelloides/aegaea group has been largely and controversially discussed by Kozur and Budurov, who repeatedly modified over time their opinions in conjunction with the diffuse taxonomic assignement and definition of timorensis versus gondolelloides, and with the successively changing current views on their chronostratigraphic range.

Kozur (1972, 1974, 1975) and Kozur \& Mostler (1972) advanced a Triassic conodont zonation, in which the "timorensis Assemblage-Zone" is placed in the upper Spathian (Keyserlingites subrobustus-Zone), followed by "aegaea S.-Z." of the "aegaea A.-Z" placed in the Lower Anisian. Shortly afterthat, Kozur (1973a, b) began to advocate that the Keyserlingites subrobustus-Zone should be placed at the base of the Anisian, by taking into con- sideration the evolution of the gondolellid conodonts, and based on the inadequate interpretation, as proved later, of the chronostratigraphic significance of ammonoid faunas around the Olenekian-Anisian boundary. Consequently, Kozur (1980a-b) and Kovács \& Kozur (1980) placed the Keyserlingites subrobustus-Zone (= Neopopanoceras haugi-Zone) and the "timorensis-zone" at the base of the Aegean, by inadequately interpreting the mixed ammonoid assemblage from Ziyun, China, discussed by Wang Y-G (1978), and on which, later, even Wang Y-G (1985) completely changed his interpretation. Finally, by adopting the ammonoid succession in Nevada and British Columbia published by Bucher (1989, 1992, 2002), Kozur (1989a, 1999, 2003 a-b) and Kozur \& Bachmann (2005) adopted a new zonation scheme, with Chiosella timorensis-Zone placed at the base of the Aegean (Japonites welteri-Zone), following upward by the Chiosella gondolelloides-Zone placed at the top of the Neopopanoceras haugi-Zone of the latest Spathian, and where the former lower Anisian "aegaea-A.-Z." is missing.

Budurov, in Budurov \& Trifonova (1974), and Budurov (1976a, b) advanced a Triassic conodont zonation where the "gondolelloides Zone aI $\beta$ " is placed in "obere Teile des Hydasp" of Bender (1970), the chronostratigraphic equivalent of the lower Anisian of Assereto (1974). In the next publications, Budurov et al. $(1983,1985,1987)$ and Budurov \& Trifonova (1984) placed the Neospathodus gondolelloides R.-Z. either on the top of the Spathian or straddling the upper Spathian-lower Anisian boundary, where gondolelloides is interpreted as the senior synonym of timorensis. When the new genus Kashmirella was introduced by Budurov et al. (1988b) to replace the generic assignment of Neospathodus gondolelloides Bender 1970 (= G. timorensis Nogami 1968), the newly named $K$. gondolelloides R.-Z. is straddling the upper Spathianlower Anisian boundary (e.g., Budurov et al., 1989; Budurov \& Trifonova, 1991), subsequently replaced by K. timorensis R.-Z. (Budurov \& Trifonova, 1994). When stated that gondolelloides and timorensis are distinct conodont species, Budurov \& Sudar (1995) and Budurov \& Trifonova (1995) have split the former K. gondolelloides R.-Z. and introduced a new zonation with the K. timorensis R.-Z. at the top of the Spathian, and the K. gondolelloides R.-Z. at the base of the Anisian. One may observe that this new proposed conodont zonation is opposite to that promoted by $\operatorname{Kozur}(1999,2003 \mathrm{a}, \mathrm{b})$ and Kozur \& Bachmann (2005), with the two zones placed in a reversed chronostratigraphic order.

In Europe, the conodont species timorensis is reported from several localities (Fig. 3/1 to 6), as follows, in the chronological order of their reports: Chios Island, Greece (Nicora, 1977; Assereto et al., 1980; Gaetani et al., 1992; Jacobshagen et al., 1993); Perşani Mountains, Romania (Mirăuţă \& Gheorghian, 1978; Patrulius et al., 1996); Capelluzzo, Southern Apennines, Italy (Mietto et al., 1991); Sosio Valley, Sicilia, Italy (Kozur et al., 1995); Kçira, Albania (Muttoni et al., 1996, 2019; Germani, 
1997); Deşli Caira, Romania (Grădinaru et al., 2000, 2006, 2007; Orchard et al., 2007a).

The status of the conodont species timorensis in the Chios and Kçira sections, and its relevance for the $\mathrm{OAB}$, were already discussed in a previous section of the present paper. Mietto et al. (1991) reported the finding of Gondolella timorensis (sensu Sweet, 1970a, 1973; Nicora, 1977; Kozur, 1989b), with gondolelloides in the synonymy of timorensis, in the Southern Apennines, and asserted that the Timorensis conodont zone characterizes the lowest Aegean Substage of Assereto (1974), thus following the Triassic conodont zonation of Sweet et al. (1971) and the conclusions of studies done by Nicora (1977) in Chios. For the Sosio Valley, Kozur et al. (1995) identified the conodont species timorensis as the index for the base of the Anisian. As regards the Deşli Caira section, the new ammonoid biostratigraphy achieved in this locality documents that the FO of the conodont species timorensis is well below the OAB (Grădinaru, in Grădinaru \& Gaetani, 2019). Mirăuţă (1974), Mirăuţă \& Gheorghian (1978) and Mirăuţă et al. (1984) mentioned the occurrence of gondolelloides/timorensis group in the lower Anisian of North Dobrogea and the Eastern Carpathians. Later, Mirăuţă (in Patrulius et al., 1996) noted that Gondolella timorensis persisted longer than G. regalis, till the Pelsonian, in the Schreyeralm Limestone from the Pleaşa Lupşei Outlier, in the Perşani Mountains. It must be underlined that Mirăuţă followed Sweet's concept of the gondolelloides/timorensis group, with gondolleloides in the synonymy of timorensis, and this is entirely proved by the illustrated specimens, among which no one can be assigned to the true timorensis.

From Southwest Asia, the occurrence of Ch. timorensis is known in Turkey and Oman. The most recent record of the conodont species timorensis is from Gebze, in Turkey (Fig. 3/7), and it was published by Kiliç (2021). Although this author noted the range of this species appears to be late Spathian to Aegean, he refers, however, in his paper to the Timorensis Zone as early Anisian in the Kokaeli Triassic succession. As regards the definition of timorensis species, Kiliç (2021, p. 627) is adopting the concept of Sweet and Budurov, with gondolelloides in the synonymy of timorensis. From Wadi Alwa, in Oman (Fig. 3/8), the occurrence of the conodont species timorensis is reported by Orchard (1994a), who stated it correlates to the basal Lower Anisian Japonites welteri beds of Nevada.

In the Himalayas region, Fucks \& Mostler (1969) early reported from northern Nepal, in the area north of Dhaulagiri (Dolpo), a conodont assemblage equivalent to the latest Spathian-earliest Anisian Timorensis conodont assemblage of Nogami (1968). Subsequently, a succession of articles have been published by Sweet (1970a, 1973) on the occurrence of the conodont species timorensis in the Salt Range, western Pakistan, from the Narmia Member of the Mianwali Formation (Fig. 3/9). In a previous section of the present paper, the twisting options of Sweet (1970a, 1973, 1988) and Sweet et al. (1971) on the first occurrence and stratigraphic range of the conodont species timorensis, having gondolelloides in its synonymy, are underlined, which jumped from the latest Spathian-earliest Anisian to the latest Spathian, and finally to the earliest Anisian. Nakazawa et al. (1975) made reference to the conodont zonation done in Pakistan by Sweet (1970a, 1973), with the Timorensis Zone placed in the uppermost Lower Triassic.

Kovács \& Kozur (1980, pl. 1, figs 1, 2, 4) illustrated Gondolella ? timorensis Nogami from Dolpo Gebiet, west Nepal (Fig. 3/10), and its occurrence is dated to the Keyserlingites subrobustus-Zone. The conodont Timorensis A-Z defined by Kovács \& Kozur (1980, tab. 1) is overlapping the Keyserlingites subrobustus-Zone and the basal part of the Paracrochordiceras anodosum-Zone, both ammonoid zones being assigned to the Aegean Substage/base Anisian Stage. Garzanti et al. (1995) recorded the occurrence of Gondolella timorensis (Nogami, 1968) from Manang, in Nepal, in the topmost Tamba Kurkur Formation, as indicating the earliest Anisian (Timorensis Zone).

From Spiti, India (Fig. 3/11), the conodont species timorensis is reported in several localities. Goel (1977) reported the abundant occurrence of Neospathodus timorensis (Nogami), with gondolelloides in its synonymy, at Guling, in Spiti, from dark shales and grey limestones with Keyserlingites dieneri and Spiriferina stracheyi, dated as Spathian.

Gupta \& Budurov (1981) and Gupta (1983) reported the occurrence of Neospathodus timorensis (Nogami) from the shaly limestones with Rhynchonella griesbachi, below the Nodular Limestone, at the base of the Anisian, in the Lilang section, Spiti, the conodont species timorensis being considered by Gupta \& Budurov (1981, p. 24) "an index species for the zone of the same name in the Upper Aegean".

Balini \& Krystyn (1997) definitely documented the Anisian age of the Durgaites dieneri Beds in Spiti Himalayas, thus ending a long-lasting discussion on their Lower or Middle Triassic position (see also Wang Y-G, 1985; Dagys \& Ermakova, 1986; Dagys, 1988; Bucher, 1989; Tozer, 1994c). Krystyn et al. (2004), based on the FO of Chiosella timorensis, placed the Olenekian-Anisian boundary in the upper part of the Niti Limestone, from which the occurrence of the ammonoid genus Preflorianitoides is reported, and considered this to be the only cephalopod found within the lowermost Anisian of the Muth section. It is to be noted that the ammonoid genus Preflorianitoides described by Wang Y-G (1978) from Zyiun, in China, in presumed Scythian-Anisian "mixed ammonoid faunas", is considered a Spathian ammonoid by Wang Y-G (1985), Tozer (1980) and Shevyrev (1990). In the Deşli Caira section, this ammonoid occurs in the latest Spathian (Grădinaru et al., 2007), besides Procarnites, Proptychitoides, Albanites, and also the ammonoid genus Procladiscites. In a previous section of the present paper, it is underlined that the occurrences of Procladiscites at Chios prompted the untenable assump- 
tion of Assereto et al. (1980, p.731) that the beginning of the Anisian is marked by the first appearance of cladiscitids, and that this would also coincide with the first occurrence of Neogondolella timorensis. Although in the Spiti section the appearance of the conodont Chiosella timorensis is reported lower than the base Aegean Durgaites dieneri ammonoid zone in the Himalayan Muschelkalk Member, the FO of the oft-cited boundary marker conodont Chiosella timorensis is nevertheless preferred by Krystyn et al. (2004) and Sue et al. (2021) as fixing the Olenekian-Anisian boundary in the uppermost part of the Niti Limestone Member, even if its Aegean age is not confidently documented by ammonoids. In conclusion, for Krystyn et al. (2004) and Sue et al. (2021) the Chiosella timorensis conodont zone is coincident with the base Aegean Durgaites dieneri ammonoid zone, although its FO is well below the first occurrence of distinct Anisian ammonoids, i.e., in the upper part of the Niti Limestone in an undefined stratigraphic interval placed between the Spathian/late Olenekian and the Aegean/early Anisian.

From Kashmir, India (Fig. 13/12), Chhabra (1981) reported the Neospathodus homeri-Neospathodus timorensis assemblage in the upper part of the Nodular Limestone dated as early Anisian, with gondolelloides as a junior synonym of timorensis. Chhabra \& Sahni (1981) suggested that the placement of the Scythian-Anisian boundary at the base of the Neospathodus timorensis Zone is in agreement with the data of Nicora (1977) from Chios and Nevada, and that this zone characterizes the lower part of the Aegean Substage as defined by Assereto (1974).

Matsuda $(1983,1985)$ reported the occurrence of Neospathodus timorensis and figured specimens from the latest Spathian in Kashmir, but the definition follows Sweet's taxonomic concept of the timorensis/gondolelloides group. Pakistani-Japanese Research Group (1985) confirmed the presence of Neospathodus timorensis Zone in Pakistan, from the Narmia Member of Mianwali Formation, and placed this in the uppermost Spathian.

From Central Asia, Bragin et al. (2016) have mentioned occurrences of early Anisian conodonts, among them Neospathodus sp. aff. N. timorensis (Nogami), from the top of the Zougan Formation in the southeastern Pamirs, Tajikistan (Fig. 3/13).

In Eastern Asia, the most important occurrences of $\mathrm{Ch}$. timorensis come from China. The first record of $\mathrm{Ne}$ ospathodus timorensis is only from the early 1980s, when Wang Z-H (1982) reported its occurrence from the Guizhou Province, South China, and dated it as Spathian based on the conodont zonation of Sweet et al. (1971). Concomitantly, N. timorensis was reported by Tian (1982) from Tulong, Tibet (Fig. 3/14), and dated as late Olenekian, but the figured specimen (pl. 13, fig. 22) is presumably a gondolelloides specimen. Wang \& Wang (1983), when summarizing the Triassic conodont biostratigraphy in China, advocated the placement of the
Neospathodus timorensis Zone at the top of the Olenekian. The newest report on the occurrence of $C h$. timorensis at Tulong, located in the Himalaya Terrane of Tibet, is by Chen A-F et al. (2021), and the first occurrence (FO) of Chiosella timorensis is credited to fix the Olenekian-Anisian boundary (OAB) at Bed 25, upper part of the Kangshare Formation, only on the basis of the data provided in the references commonly used in this matter (Grădinaru et al., 2006; Orchard et al., 2007a, 2007b; Orchard, 2010; Chen Y et al., 2020). Wu G-C et al. (2007) reported the occurrence of Ch. timorensis from Dibucuo, in the Lhasa Terrane of Tibet (Fig. 3/14), and this in placed also at the base of the Anisian.

When the conodont species Chiosella timorensis was agreed by the ICS in 2002 as a primary biotic proxy for the Olenekian-Anisian boundary (cf. Kozur 2003a), a suite of articles concentrated on the conodont biostratigraphy around the $\mathrm{OAB}$ in the Triassic successions from several localities in Guizhou Province, South China (Lehrmann et al., 2002, 2015 a-b; Yao et al., 2004, 2011; Wang et al., 2005; Orchard et al., 2007b; Ji et al., 2011; Yan et al., 2015; Liang et al., 2016; Chen Y et al., 2020). The section of Guandao (Fig. 3/15) has been advanced as a reference GSSP for the base of the Anisian Stage/Middle Triassic Series (cf. Gradstein et al., 2004). The chronostratigraphic interpretation of the conodont biostratigraphy in the Guandao section (Orchard et al., 2007b), for which there are no ammonoid data to properly document the Olenekian-Anisian boundary, is purely mimicking the chronostratigraphic interpretation given to the ammonoid/conodont record in the Deşli Caira section (Grădinaru et al., 2007; Orchard et al., 2007a). On this basis, Ji et al. (2011, and Chinese references therein) furthermore support the conodont Ch. timorensis as a proxy for the Lower-Middle Triassic boundary in the Guandao section. When Tong et al. (2019) discussed the Anisian Stage in China, it was confirmed once more that the Guandao section lacks ammonoids around the OAB boundary.

Two other localities in the Guizhou Province, Wantou and Youping (Fig. 3/16), are recently advanced by Ogg (2019) and Chen Y et al. (2020) as potential GSSP candidates for the Olenekian-Anisian/Early-Middle Triassic boundary, further supporting the conodont Chiosella timorensis as a proxy for this boundary. Even more, the taxonomic definition by Chen Y et al. (2020) of the conodont species Chiosella timorensis is consistently different when compared to the definition given by Goudemand et al. (2012), thus making more complicated the taxonomy and the lineage of the gondolelloides/timorensis group. Intentionally, or not, in the stratigraphic diagrams of the two "exceptional" Chinese localities, the Olenekian-Anisian/Early-Middle Triassic boundary is not properly indicated. It seems the placement of the Olenekian-Anisian boundary in the "exceptional" Chinese sections represented a great dilemma even for the mentioned authors, and such an undecision is astonishing to the readers of their article. The two "ex- 
ceptional" Chinese localities are devoid of ammonoids just in the stratigraphic interval of their sections that is critical to fix the Early-Middle Triassic boundary. Additionally, the two "exceptional" Chinese sections have rapid lithological changes, just in the stratigraphic interval where potentially the boundary could be placed, and this represents a major bias for the ammonoid occurrence in the two "exceptional" Chinese sections. As already showed in a previous section of the present paper, Ogg (2019) and Chen Y et al. (2020) centered their discussion mostly on the Early-Middle Triassic boundary interval, as is indicated explicitly in the titles of their articles, and not properly on the boundary itself. This may explain why the boundary location is not shown in the two "exceptional" Chinese sections, for which Chen Y et al. (2020, p. 12) amazingly concluded to have great potential as important GSSP reference sections for the Early-Middle Triassic boundary and can enable precise global correlation.

Recently, Ogg et al. (2020b) noted that "The lowest occurrence of the Chiosella timorensis (or its sensu stricto morphotype on its early lineage) conodont slightly precedes the Anisian ammonoid level and can be correlated to North American and Asian stratigraphy". Furthermore, with the desire to find a solution for this incongruence, Ogg et al. (2020b) stated "If the lowest occurrence of $\mathrm{Ch}$. timorensis is selected as the global marker, then the uppermost part of the ammonoid Neopopanoceras haugi Zone of "latest Olenekian" in theTethyan realm will slightly overlap the basal Anisian".

Ogg et al. (2020b), in their obsession to further suport the conodont species timorensis as a primary biotic proxy for the base of the Anisian, intentionally ignore that the Neopopanoceras haugi zone is the penultimate ammonoid zone in the late Spathian of Nevada, being followed by the Courtilloticeras stevensi ammonoid zone (e.g., Monnet et al., 2013, fig. 2), and also ignore that the classic Neopopanoceras haugi ammonoid zone from western Nevada, as defined by Silberling \& Tozer (1968), correlates with the Keyserlingites subrobustus ammonoid zone in British Columbia, Arctic Canada and Arctic Europe, and with the Olenekites spiniplicatus ammonoid zone in Arctic Siberia (e.g., Dagys \& Tozer, 1989; Dagys \& Weitschat, 1993; Tozer, 1994a; Dagys \& Sobolev, 1995). By adopting the suggestion of Ogg et al. (2020b), then a major instability in the standard Triassic timescale would be introduced as regards the Olenekian-Anisian boundary. Although on a recent Research Gate Forum it has been endorsed once more that the ammonoids are the taxonomic group with the highest power of temporal resolution within the Triassic (see also Jenks et al., 2015), the conodont workers continue their offensive in promoting the conodonts as primary biotic proxies to define or redefine the boundaries in the standard Triassic timescale (see Ogg et al., 2020b).

In Southeast Asia, the occurrence of the conodont species timorensis was early reported by Koike (1973) from
Kodiang, Malaysia (Fig. 3/17), and the author dated it as "early (or middle) Anisic", but the illustrated specimen (pl. 16, fig. 15) is an indeterminate fragment. Kemper et al. (1976) reported the occurrence of timorensis from western Thailand (Fig. 3/18), and dated it as late Spathian to early Anisian, but the figured specimens (pl. 6, figs. 3a-b) likely belong to the conodont species gondolelloides. It must be underlined, Koike (1973) and Kemper et al. (1976) have treated gondolelloides as the junior synonym of timorensis, by adopting Sweet's taxonomic concept on the gondolelloides/timorensis group.

In the Japanese Islands, the occurrence of the conodont species timorensis was reported starting from the earliest 1970s. Data have been summarized by Koike (1979a-b, 1981), Ishida (1979), Watanabe et al. (1979), Tanaka (1980), Igo \& Koike (1983) and Nakazawa et al. (1994), who stated that the Neogondolella (= Chiosella) timorensis Zone, both in the Triassic pelagic carbonate and cherty successions, indicates the uppermost Spathian to the lowermost Anisian, which reflects the opinion current at that time on the first occurrence and stratigraphic range of the conodont species timorensis. In the last decades, several authors reported on the occurrence and stratigraphic range of the conodont species timorensis in Japan. Hirsch \& Ishida (2002) and Maekawa et al. (2018), summarizing the conodont data from the Chichibu terrane pelagic carbonates, at Kamura, Kyushu Island, and Taho, Shikoku Island (Fig. 3/19), placed the conodont fauna with $C h$. timorensis in the lowermost Aegean (Lower Anisian). To calibrate the Lower Triassic $\mathrm{d}^{13} \mathrm{C}$ isotope curve from shallow-marine pelagic carbonates in the classic Kamura section, Horacek et al. (2009) placed the Chiosella timorensis Zone in the lower Anisian, following the current concept with this conodont species as a primary biotic proxy for the base of the Anisian. Subsequently, Zhang L et al. (2019a), referring to the same section from Kamura, to overcome the unrealibility of Chiosella timorensis as a primary biotic proxy for the $\mathrm{OAB}$ due to the new data on the ammonoid-conodont succession in Nevada, which demonstrated that its FAD is in the late Spathian, asserted that the earliest Anisian age is coincident to the Chiosella ex gr. timorensisCratognathus Zone. By this, the authors assumed that the coexistance of Ch. timorensis, Ch. n. sp. B and Cratognathus sp. B at Kamura suggests an earliest Anisian age by reference to the conodont succession in the Deşli Caira, Romania and Guandao, South China sections.

Ha et al. (2021) report on the occurrence of Ch. timorensis in the Triassic carbonate succession from the Taho Formation in western Shikoku Island. By referring to Goudemand et al. (2012), who revised the conodont succession of the Deșli Caira section (candidate section of $\mathrm{OAB}$ ) and proposed that the FO of Chiosella n. sp. A indicates the $\mathrm{OAB}$ for conodont successions, Ha et al. (2021) stated that Chiosella n. sp. A occurs in the study area slightly above the FO of $C$. timorensis and continues upwards, and asserted that the Ch. timorensis Zone probably contains the ammonoid-based OAB. 
For the chronostratigraphic calibration of the Panthalassic Triassic pelagic deep-sea chert stacked in the Jurassic accretionary complex of southwestern Japan, located mainly on Honshu Island (Fig. 3/20), Muto et al. (2018, 2019, 2020) and Muto (2021) assumed that the horizon corresponding to the traditional $\mathrm{OAB}$, due to lower biostratigraphic resolution, should essentially be the same as the first occurrence (FO) of Ch. timorensis, based on comparison with conodont occurrences in Tethyan pericontinental sections, although they noted, however, that in Nevada the ammonoid-conodont succession documents the first appearance of this conodont species in the late Spathian.

In Northeast Asia, the issue of the first occurrence and chronostratigraphic range of the timorensis/gondolelloides group received particular attention from the Russian conodont researchers. Some of the formerly reported occurrences were updated or revised. For example, Neospathodus timorensis (Nogami) mentioned by Dagys (1984) in the upper Olenekian from eastern Taimyr is interpreted by Sobolev \& Klets (2009) as Chiosella gondolelloides (Bender), and it is part of the latest Olenekian Paragondolella $(=$ Neogondolella $)$ paragondolellaeformis conodont zone.

The lower Anisian occurrence of Neospathodus timorensis is reported by Bragin (1991) in the Ekonai terrane of the Koryak Upland (Fig. 3/21), in association with radiolarian assemblages. Neospathodus aff. timorensis is reported from Zyryanka, Kolyma (Fig. 3/22) by Konstantinov et al. (1997) and Klets (1998), subsequently being assigned by Klets \& Kopylova (2008) to the new species Chiosella omulyovika Kopylova and Klets. This occurs in a conodont assemblage together with Neogondolella taimyrensis Dagys, N. jubata Sweet, Paragondolella paragondolellaeformis (Dagys), and Chiosella crepidica Klets and Kopylova, and is assigned to the upper Olenekian according to Klets \& Kopylova (2008) and Konstantinov \& Klets (2009).

Buryi (1989) and Klets (1995) described and figured $N$. timorensis from Sikhote-Alin (Fig. 3/23) and stated that its stratigraphic range corresponds to the latest Olenekian-lowest Anisian boundary interval. Buryi (1997) reported the occurrence of the conodont species timorensis in cherts along the Rudnaya River, Dalnegorsk region, Sikhote-Alin, which are exotic enclosures in the Early Cretaceous turbidites of the Taukha allochthonous terrane. In the opinion of Buryi (1997, p. 49), Neospathodus timorensis Zone defines the interval of Aegean, Bithynian and lower Pelsonian.

Burij et al. (1976) stated early that $N$. timorensis is absent in South Primorye (Fig. 3/24) due to the erosion of the uppermost layers of the Lower Triassic in pre-Anisian time. Later, Buryi (1979) reported the occurrence of $N$. timorensis in South Primorye in allochthonous late Olenekian limestone blocks, which are embedded in Ladinian terrigenous deposits occurring in the basin of the Chernaya River (Sobolev, pers. commun.).
Klets $(2005,2006,2008)$ synthesized all information and the current views on the Triassic conodont occurrences and conodont-based geochronology in Northeast Asia.

Konstantinov \& Klets (2009, p. 179), when discussing the Anisian Stage in Northeast Asia, stated that conodonts, in particular the FO of Chiosella timorensis (Nogami), appear to be inappropriate biomarkers. Firstly, because the content of the Chiosella timorensis group and its stratigraphic distribution are ambiguously understood, and secondly, because undoubtfully-defined Chiosella timorensis has not been found as yet in the Triassic sections of Northeast Asia. The statement of Konstantinov \& Klets (2009) is fully justified in view of the problems relating to the definition of timorensis versus gondolelloides, as proved by the synonymies, descriptions and illustrations done by Buryi $(1979,1989)$ and Klets (1995).

In Timor, the conodont species timorensis was first described by Nogami (1968) from Mount Lilu (Fig. 3/25), in Timor-Leste (cf. Charlton et al., 2009). In a previous section of the present paper the subsequent consequences resulting from the uncertain dating of its occurrence and stratigraphic range were underlined. Orchard (1994a) reported the occurrence of the conodont species Chiosella timorensis, together with fewer Gladigondolella tethydis and a single specimen of Neogondolella ex gr. regale, from Nifukoko (Fig. 3/26), in West Timor (cf. Charlton et al., 2009), from an allochthonous Hallstatt limestone block, and dated it as Early Anisian based on his current concept on the FO of Ch. timorensis. The assertions of Orchard (1994a, p. 110) with regard to the age of the conodont timorensis in the West Timor block are opposed to the assertions by Tozer (1994c), who assumed the late Spathian to earliest Anisian dating of the ammonoids in the condensed Hallstatt-type limestone in the studied block. However, the dating of ammonoids, also of the associated conodont fauna, in the West Timor block, is not yet clearly defined, as the assertions of Tozer (1994c) about the ammonoids Keyserlingites versus Durgaites and their stratigraphic ages are not fully justified by the actual data (e.g., Balini \& Krystyn, 1997; Krystyn et al., 2004).

From Western Australia, the occurrence of the conodont species timorensis was early reported by McTavish (1973, 1975), who adopted Sweet's taxonomic concept, with gondolelloides in the synonymy of timorensis, and placed the Neospathodus timorensis Zone in the late Spathian. Subsequently, the conodont Chiosella timorensis Zone was treated as early Anisian by Nicoll \& Foster (1998), Nicoll (2002) and Nicoll et al. (2007). Subsequently, Gorter et al. $(2008,2019)$ reported the occurrence of the conodont species timorensis in the offshore Carnarvon, Perth \& Canning basins (Fig. 3/27), and asserted it is a good approximation of the OAB, although the authors noted, however, this conodont species occurs first with upper Spathian Haugi Zone ammonoids in Nevada. 
From the western United States, significant data on the discussed issue in the present section originated, and it must be noted from the very beginning these generated major controversies regarding the first occurrence and chronostratigraphic range of the timorensis/gondolelloides group. Collinson \& Hasenmueller (1978) reported Neospathodus homeri and Neogondolella timorensis from the Haugi ammonoid zone in the lower Prida Formation of the Humboldt Range in northwestern Nevada (Fig. 3/28), which is documented as latest Spathian by Silberling \& Wallace (1969). Subsequently, the occurrence of timorensis in the western United States was reported by Clark et al. (1979), Wardlaw \& Jones (1980), Carey (1984) and Paull (1988). Carey (1984) classed the occurrence of Ch. timorensis in northwestern Nevada as latest Spathian to earliest Anisian. Instead, Paull (1988, and reference therein), by following the conodont zonal scheme of Sweet \& Bergström (1986), noted that the Timorensis zone, the uppermost zone of the Lower Triassic, is commonly reported from Nevada, where Neospathodus (or Neogondolella) timorensis is often present in abundance.

Wardlaw \& Jones (1980) reported the occurrence of Neospathodus timorensis, presumably straddling the Spathian-Anisian boundary, from Great Valley, California Coast Ranges (Fig. 3/29). From east-central California, Stone et al. (1991) reported Chiosella sp. cf. Ch. timorensis found at a presumably stratigraphic level above the Haugi Zone. The occurrence of the conodont species timorensis is also reported from Sheep Creek, southeastern Idaho (Fig. 3/30) by Carr (1981, unpubl. PhD thesis), as noted by Paull (1988). Clark \& Carr (1984, fig. 9) interpreted the occurrence of Neogondolella timorensis as diagnostic of the latest Early or earliest Middle Triassic, as a distinct zone in their Idaho Lower Triassic conodont zonation.

Orchard \& Bucher (1992, p. 136) and Orchard (1994a, p.108) revised Collinson's material, and based on new conodont faunas from the Haugi Zone (Yatesi beds) in the same area, concluded that the conodont species timorensis is unconfirmed in the respective conodont fauna that is dominated by $N$. ex gr. homeri, with some elements approaching Chiosella gondolelloides (Bender). Instead, Orchard \& Bucher (1992, p. 136) and Orchard (1994a, p. 108) documented that only the basal Anisian Japonites welteri beds of Bucher (1989) include Chiosella timorensis. Based on the above data, Orchard (1994a, pp. 108 and 111) concluded that " $\boldsymbol{C}$. timorensis has a worldwide occurrence and appears to be a suitable index for the base of the Middle Triassic, as has been suggested by several authors (e.g., Assereto et al., 1980)", and stated that "On the basis of Nevadan and Canadian data the appearance of Chiosella timorensis provides a suitable datum for defining the LowerMiddle Triassic boundary".

Paull \& Paull (1998) reported the occurrence of Neogondolella timorensis unaccompanied by neospathodid species from O'Neil Pass in northeastern Nevada, and these authors agreed with Orchard (1995) that "Chiosella timorensis (Nogami), although it closely predates known Anisian ammonoids (Gaetani et al., 1992), represents the best conodont datum for definition of the base of the Middle Triassic".

In a previous section in the present paper, there were already underlined the shortcomings in the statements of Assereto et al. (1980) with regard to the dating of the first occurrence of Ch. timorensis, and its relevance for the base of the Lower-Middle Triassic boundary. In the same section, it was emphasized that Gaetani et al. (1992, p. 197) in opposition stated that the conodont Gondolella timorensis (= Chiosella timorensis), which appears before the appearance of the first Anisian ammonoid fauna in the Chios section, cannot be used to define the base of the stage exactly, because its appearance approximates the beginning of the Anisian only in a broad sense.

Finally, the issue of the FAD of Chiosella timorensis in Nevada has been definitely resolved by Goudemand et al. (2012), who documented that this conodont species occurs in the Haugi Zone in the northern Humboldt Range (Nevada, USA), which has been classically placed by Silberling \& Tozer (1968), Silberling \& Nichols (1982), Bucher (1989) and Guex et al. (2010) in the late Spathian Substage, i.e., the last substage of the Spathian/late Olenekian/Early Triassic in the North American Triassic chronostratigraphy. So, for the first time the inadequacy of the FAD of Chiosella timorensis as a marker of the Olenekian-Anisian boundary is fairly documented by the ammonoid chronostratigraphy. The data provided by Goudemand et al. (2012) have been later supplemented by Ovtcharova et al. (2015), and these authors firmly demonstrated that Chiosella timorensis occurs in the conodont faunas of the latest Spathian of Nevada, including the Haugi and Stevensi zones, the penultimate and ultimate ammonoid zones of the latest Spathian, respectively, as documented by the comprehensive study of the Spathian ammonoid faunas from the western USA done by Guex et al. (2010). As a result, Goudemand et al. (2012) and Ovtcharova et al. (2015) reasonably questioned, based on undeniable ammonoid data, the usefulness of the FAD of Ch. timorensis as an index for the OlenekianAnisian boundary. Ovtcharova et al. (2015), through the application of Unitary Association, defined a succession of two laterally reproducible maximal associations/conodont biozones between which the OlenekianAnisian boundary falls, where the residual maximal horizon including Ch. timorensis is placed below the OAB. It has been concluded that the chronostratigraphic location of the OAB remains to be resolved at a later date in a succession having a complete ammonoid record around the Olenekian-Anisian boundary, to which the conodont record has to be closely tied.

In Western Canada, the timorensis fauna is differentiated by Orchard \& Bucher (1992) and Orchard \& Tozer (1997a, fig. 4) as a basal Anisian interval at Ursula Creek, northeast British Columbia (Fig. 3/31), belonging to the North American craton-bound Triassic, and 
also in the western Cordilleran allochthonous terranes of Canada, i.e., in Quesnellia (Fig. 3/32) and in Stikinia (Fig. 3/33), by correlation with the basal Anisian Japonites welteri beds of Nevada. However, Orchard (1994, p. 107) and Orchard \& Tozer (1997a, fig. 4) noted Ch. timorensis, potentially defining the base of the Middle Triassic, is known from otherwise undated strata in Canada. Golding (2014) mentions Chiosella timorensis from the Montney Formation in the subsurface of northeast British Columbia, as indicating the uppermost Spathian or the Anisian. Pointing out that the first occurrence of Chiosella timorensis is known to occur with Spathian (upper Olenekian) ammonoids of the Neopopanoceras haugi Zone in Nevada and China, as stated by Goudemand et al. (2012), Golding et al. (2014) concluded that its use as a definitive index species for the base of the Anisian is questionable, as this would require the Neopopanoceras haugi Zone to be re-defined as Anisian in part. Subsequently, specimens of Ch. timorensis have been described by Golding et al. (2015) from the subsurface of British Columbia in the Petro-Canada Kobes d-048-A/094-B-09 and Shell Groundbirch 16-02078-22 W6 wells. Golding (2021b) reported the finding of Ch. timorensis in the subsurface of British Columbia, with only one specimen, and the author concluded, having in view the co-occurrence of the conodont Neogondolella bifurcata, that this suggests the Anisian.

In Arctic North America, Wardlaw \& Jones (1980) reported the occurrence of Neospathodus timorensis in the Brooks Range, Alaska (Fig. 3/34), but the single illustrated specimen is of doubtful identity. It may be assigned to the Spathian conodont genus Borinella (Golding, pers. commun.).

In Arctic Europe, Nakrem et al. (2008) and Hounslow et al. (2008), in their attempt to elaborate an integrated biomagnetostratigraphic intercalibration of the Boreal and Tethyan timescales, reported the occurrence of a single specimen of Chiosella cf. timorensis in the lower Botneheia Formation in the Milne Edwardsfjellet section in central Svalbard (Fig. 3/35), the authors implying an early Anisian age by reference to Kçira, Albania and Deşli Caira, Romania sections.

As may be seen, the FO of the occurrences conodont species timoresis have been dated either as late Spathian (e.g., Nogami, 1968; Sweet et al., 1971; Kozur, 1972, 1974, 1975; Kozur \& Mostler, 1974; McTavish, 1973, 1975; Goel, 1977; Collinson \& Hasenmueller, 1979; Tian, 1982; Wang \& Wang, 1983; Matsuda, 1983, 1985; Paull, 1988; Budurov \& Sudar, 1995; Budurov \& Trifonova, 1995), either as early Anisian (e.g., Sweet, 1970a; Koike, 1973; Budurov, 1976a-b; Nicora, 1977; Kozur, 1980 a-b, 1989 a, 1999, 2003a-b; Gupta \& Budurov, 1981; Chhabra, 1981; Gupta, 1983; Sweet, 1988; Mietto et al., 1991; Orchard, 1994a, 1995; Orchard \& Bucher, 1992; Orchard \& Tozer, 1997a; Garzanti et al., 1995; Kozur et al., 1995; Krystyn et al., 2004; Wu G-C et al., 2007; Grădinaru et al., 2007; Orchard et al., 2007a-b; Nicoll et al., 2007; Horacek et al., 2009; Gorter et al.,
2019; Yao et al., 2011; Yan et al., 2015; Liang et al., 2016; Bai et al., 2017; Li M et al., 2018b; Zhang L et al., 2019a; Chen Y et al., 2020; Muto et al., 2020; Muto, 2021; Sue et al., 2021; Song et al., 2021; Kiliç, 2021; Ha et al., 2021; Chen A-F et al., 2021), or straddling the late Spathian-early Anisian boundary interval (e.g., Kemper et al., 1976; Koike, 1981; Igo \& Koike, 1983; Sweet \& Bergström, 1986; Lozovsky et al., 1989; Buryi, 1989; Budurov et al., 1989; Budurov \& Trifonova, 1991, 1994; Nakazawa et al., 1994; Klets, 1995).

Also, one may observe that many conodont workers have changed through time their options with regard to the stratigraphic range of the conodont species timorensis. It is related either to the changing of the taxonomic interpretation of the timorensis versus gondolelloides or to the uncertainities in chronostratigraphic dating of the occurrences of these two conodont species. In most of the older reported occurrences, gondolelloides was placed in the synonymy of timorensis (e.g., Sweet, 1970a, 1973; McTavish, 1973; Kozur, 1973b; Mirăuţă, 1974; Kemper et al., 1976; Matsuda, 1983; Assereto et al., 1980; Gaetani et al., 1992; Buryi, 1979, 1989; Budurov \& Trifonova, 1994; Klets, 1995), or timorensis was placed in the synonymy of gondolelloides (e.g., Budurov, 1976b; Buryi et al., 1980; Budurov et al., 1983, 1985, 1987, 1988a-b, 1989; Budurov \& Trifonova, 1991). This gives rise to uncertainties with regard to many of the older reported occurrences of the true conodont species timorensis.

Plasencia et al. (2013), based on a comprehensive revision of the Triassic conodont literature, found that the stratigraphic range of Ch. timorensis is from the late Spathian to the early Pelsonian. Qin et al. (2021) noted, like Buryi (1997), that in Sikhote-Alin, Far East Russia, Ch. timorensis has its youngest occurrences in the lower part of the Illyrian in the Shaiwa section, Guizhou, South China.

The above data cast major doubt on the defintion of the $\mathrm{OAB}$ by having the conodont species timorensis as a primary biotic proxy, and also with regard to its suitability as an index species to define an Aegean/lower Anisian Timorensis conodont zone. As the conodont species timorensis has its FO in the late Spathian and the HO in the lower part of the Illyrian, if the last is proved true, and having in view also its isolated occurrences, in most cases not properly tied chronostratigraphically to other index fossils, this conodont species has no credible potential to define the $\mathrm{OAB}$.

One may conclude that Chiosella timorensis, in most cases having uncertain or controversial definitions, or having scarce or doubtful occurrences in many regions, is not qualified to be a primary biotic proxy for the base of the Middle Triassic Series. There is no unitary definition yet, unanimously accepted, of the condont species timorensis, whereas its stratigraphic range remains very diffuse. 


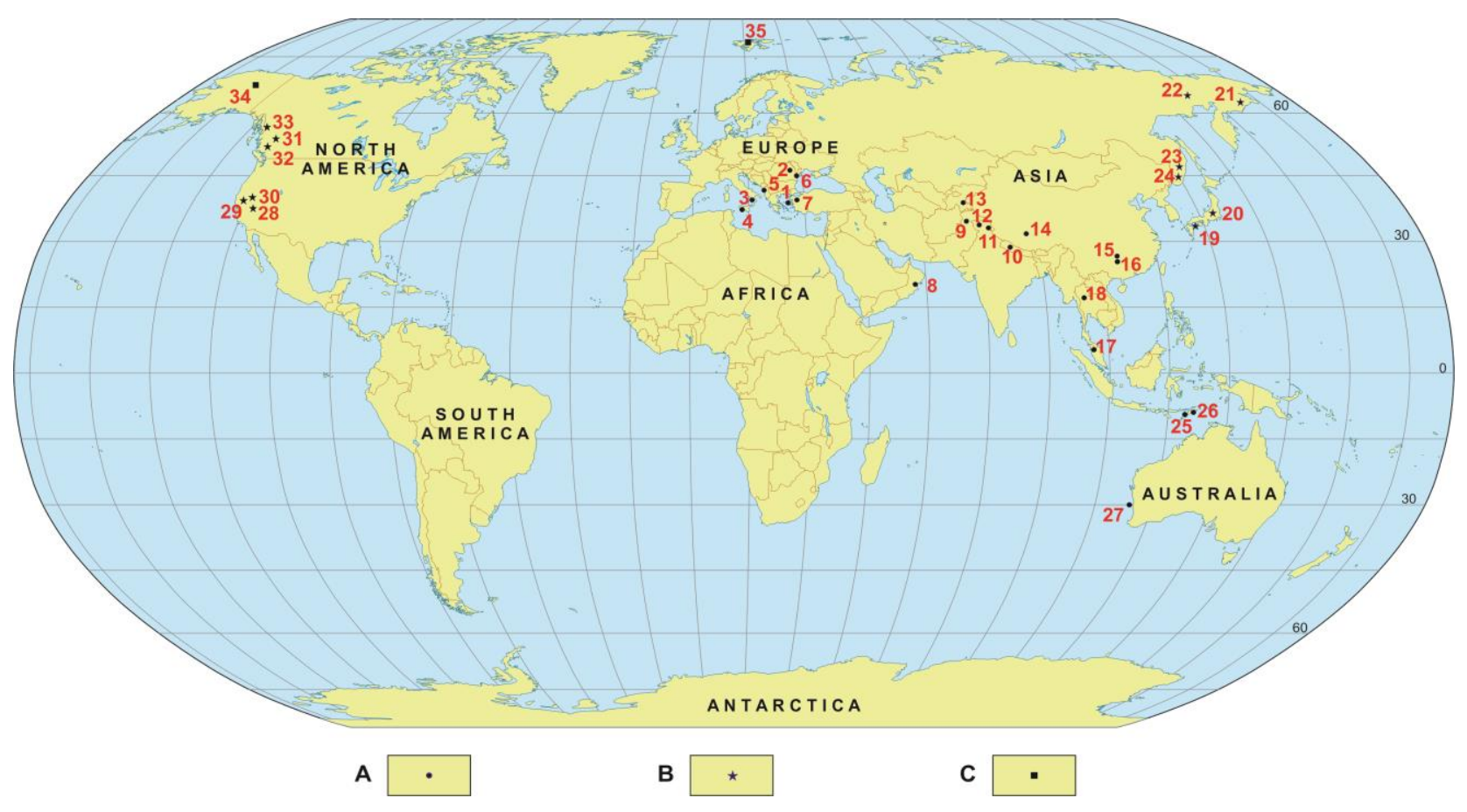

Fig. 3 - Present-day geographic distribution of the conodont Chiosella timorensis occurrences and basic references.

A - Tethys-originating occurrences (1-18, 25-27); B - Panthalassa-originating occurrences (19-24, 28-33; C - Arctic occurrences, uncertain (34-35).

Europe: 1 - Chios, Greece (Nicora, 1977; Assereto et al., 1980); 2 - Perşani Mountains, Romania (Mirăuţă \& Gheorghian, 1978); 3 - Capelluzzo, Southern Apennines, Italy (Mietto et al., 1991); 4 - Sosio Valley, Sicilia, Italy (Kozur et al.,1995); 5 - Kçira, Albania (Muttoni et al., 1996, 2019); 6 - Deşli Caira, Romania (Grădinaru et al., 2007; Orchard et al., 2007a); Southwest Asia: 7 - Gebze, Turkey (Kiliç, 2021); 8 - Wadi Alwa, Oman (Orchard, 1994a); Himalayas: 9 - Salt Range, Pakistan (Sweet 1970a, 1973 ); 10 Dolpo, west Nepal (Kovács \& Kozur, 1980); 11 - Spiti, India (Krystyn et al., 2007; Sue et al., 2021); Garzanti et al., 1995$)$; 12 Kashmir, India (Chhabra, 1981; Matsuda, 1983); Central Asia: 13 - Southeastern Pamirs, Tajikistan (Bragin et al., 2016); Eastern Asia: 14 - Tulong and Dibucuo, Tibet (Tian 1982; Chen A-F et al., 2021; Wu G C. et al., 2007); 15 - South China, Guandao (Orchard et al., 2007b), Ganheqiao and Qingyan (Yao et al., 2011); 16 - South China, Wantou and Youping (Chen Y et al., 2020); Southeast Asia: 17 - Kodiang, Malaysia (Koike, 1973, 1982); 18 - Western Thailand (Kemper et al., 1976); Japanese Islands: 19 - Kamura and Taho attol carbonates, Kyushu Island and Shikoku Island (Hirsch \& Ishida, 2002; Zhang L et al., 2019a; Ha et al., 2021); 20 - Honshu Island-pelagic chert (Muto et al., 2018; Muto, 2021); Far East Russia: 21 - Koryak Upland (Bragin, 1991 ); 22 - Zyryanka, Kolyma river; Klets (1998); 23 - Dalnegorsk, Sikhote-Alin (Buryi, 1989, 1997; Klets, 1995); 24 - Chernaya River, South Primorye (Buryi, 1979); Timor-Leste: 25 - Mount Lilu (Nogami, 1968); West Timor: 26 - Nifukoko (Orchard, 1994a); Western Australia: 27 - Carnarvon, Perth \& Canning basins (McTavish, 1973; Nicoll et al., 2007; Gorter et al., 2019); Western United States: 28 - Northwestern Nevada (Collinson \& Hasenmueller, 1978; Orchard, 1994a; Paull \& Paull, 1998; Goudemand et al., 2012); 29 - Great Valley, California (Wardlaw \& Jones, 1980); 30 - Sheep Creek, Idaho (Paull, 1988); Western Canada: 31 Ursula Creek, British Columbia (Orchard \& Tozer, 1997a); Subsurface British Columbia (Golding, 2014, 2021 b); 32 - Quesnellia (Orchard \& Tozer, 1997a); 33 - Stikinia (Orchard \& Tozer, 1997a); Arctic North America: 34 - Brooks Range, Alaska (Wardlaw \& Jones, 1980). Arctic Europe: 35 - Svalbard (Nakrem et al., 2008).

\section{Chiosella timorensis, a conodont species without a cosmopolitan occurrence}

The known occurrences of the conodont species timorensis in Europe and Southwest Asia are all located in the western Tethys realm (Fig. 4/1-7), i.e., Chios Island, in Greece, Kçira, in Albania, Capelluzzo and Sosio, in Italy, Perşani Mts and Deşli Caira, in Romania, Gebze, in Turkey. Its occurrence in the Boreal realm of Europe (Fig. $4 / 35$ ) is questionable.

In the western United States, the conodont species timorensis has confirmed occurrences in Nevada (Fig. 4/28), which was located at a low-latitude during the Triassic on the eastern rim of Panthalassa (Orchard \& Bucher, 1992). In northeast British Columbia, Canada
(Fig. 4/31), the conodont species timorensis has a highlatitude North American craton-bounded occurrence. Its occurrence is reported also from the western Cordilleran allochthonous terranes of Canada (Fig. 4/32-33) and these were positioned at low-latitudes during the Triassic, being tectonically transported to higher latitudes during the Cenozoic oblique subduction of the Pacific oceanic plate under the North American continental plate (Tozer, 1982; Silberling et al., 1984, 1992, 1997; Orchard, 1991). Orchard \& Bucher (1992) underlined "the relatively common occurrence of Chiosella in the accreted terranes may represent remanants of a fauna that was particularly widespread in low-latitudes", suggesting a 'Tethyan' affinity. Paull (1988, p. 602), when discussing Early Triassic diversity and paleoceanography, stated that 
the distribution of conodonts, with the Timorensis zone placed at the top of the Lower Triassic, is remarkable, with an equatorial span of about $20,000 \mathrm{~km}$ from the east Tethys embayment to western North America. In agreement with the Triassic paleogeographic reconstruction done by Tozer (1982), Paull (1988) noted that the west coasts of Pangaea were bounded by vast regions of scattered islands and shoals-suspect terranes "in waiting", lying well offshore of what is present-day western North America, some $5,000 \mathrm{~km}$ south and westward into the open ocean.

The occurrence of the conodont timorensis in Boreal realm of North America is uncertain (Fig. 4/34). In Arctic Siberia the occurrence of the conodont species timorensis is not confirmed (see Sobolev \& Klets, 2009).

In Central and East Asia, most occurrences of timorensis are reported from the Himalayan region, from South China, and from the Japanese Islands. Isolated timorensis occurrences are reported from Southeast Asia. Most of these regions were located in the eastern Tethyan realm, and were welded to Eurasia by the closure of the PaleoTethys (see Metcalfe, 1990a-b, 1998, 2013; Wakita \& Metcalfe, 2005; Hirsch et al., 2006; Ishida \& Hirsch, 2011, fig. 11). The Japanese terranes with Triassic pelagic deep-sea cherts and shallow-marine atoll carbonates bearing timorensis occurrences (Fig. 4/19-20) originated from low-latitude and equatorial Panthalassa (see Matsuda \& Isozaki, 1991; Hirsch \& Ishida, 2002, fig. 5; Muto et al., 2018, fig. 1; Muto, 2021, fig. 1; Zhang L et al., 2019a, fig. 2), being tectonically accreted during the scraping-off process of ocean-derived materials at the Japanese convergent margin (e.g., Isozaki et al., 1990; Wakita \& Metcalfe, 2005).

With regard to Far East Russia, it is to be noted that most of the regions where timorensis occurrences have been reported, although many of them are doubtful and not properly dated by ammonoid biostratigraphy, are in allochthonous terranes (Nokleberg et al., 1994; Vishnevskaya \& Filatova, 1994; Parfenov et al., 2009), which during the Triassic were positioned in low-latitudes in the eastern Panthalassa (Fig. 4/21-24), as documented by the occurrence of Monotis bivalves, conodonts, radiolarians, and of Rhabdoceras ammonoids (Chekhov, 1982; Dagys et al., 1983; Bragin, 1991; Klets, 2008; Grădinaru \& Sobolev, 2010). Liu K et al. (2021), based on detrital zircon $\mathrm{U}-\mathrm{Pb}$ data and also on geochronological data, argued that in Sikhote-Alin different sedimentary rocks were juxtaposed by syn- and post-subduction sinistral displacements along the NE Asian continental margin during the late Mesozoic.

With regard to the occurrences of the conodont species timorensis in offshore Western Australia, McTavish (1975) and Nicoll (2002) placed the occurrences of Chiosella timorensis on the Gondwana margin of the Tethys Ocean (Fig. 4/27). Paleogeographically, the timorensis occurrence in offshore Western Australia, together with all occurrences in Oman (Fig. 4/8), Himalayan regions (Fig. 4/9-12), Malaysia (Fig. 4/17-18) and Timor (Fig.
4/25-26), some of them being positioned around south $30^{0}$ latitude by McTavish (1975, fig. 36), were located mainly in the southern Tethys realm.

With regard to the provincialism in the geographic distribution of the Triassic conodonts, Huckriede (1958) was the first to note a distinction between faunas of the Alpine and Germanic Muschelkalk areas. Mosher (1968) added the western North America province, and underlined that connections between the Germanic Muschelkalk and western North American areas may have been either polar or to the southeast through the Tethys seaway.

Kozur \& Mostler (1972) and Kozur (1973c, 1980b) distinguished three main faunal provinces, the Northern Boreal province, the Southern Boreal province and the Tethyan province between the former. Within the Tethyan main province several regional provinces were segregated, i.e., Nevadian, Asiatic, Dinaric, Austroalpine, West Mediterranean (= Sephardic) and Germanic, some of them having subprovinces. For the mentioned authors, the occurrences of the conodont species timorensis are confined only to the Tethyan province starting from Nevada through Japan, South China, Primorye, Southeast Asia, Timor, Western Australia, Tibet, and from Himalayas until the east of the Mediterranean region, with the occurrence from Chios, the only one known at that time (see Kozur, 1980b, fig. 1).

Matsuda (1985, fig. 3) identified two conodont faunal provinces in the Early Triassic "Tethys Realm", namely the PeriGondwana Tethys Province (Kashmir, Salt Range, Spiti Himalayas, Dolpo and Thakkhola area of Nepal, the Mt. Everest area of Chinese side and western Australia) and the Tethys Province s.str. (Southern Alps, Transcaucasia, Iran, Afghanistan, South China, Malaysia, Japan and Sikhote-Alin), respectively. The author stated that the conodont assemblage of the N. timorensis Zone, which is dated as late Olenekian, is quite uniform in composition everywhere it is known, and it is found in Chios, Kashmir, Salt Range, Spiti, Nepal, Western Australia, Timor, South China, Japan and Nevada. Paull (1988, p. 600) noted that the Lower Triassic of the Western United States, with Timorensis zone at its uppermost part, includes representatives from both of Matsuda's (1985) faunal provinces.

Hirsch \& Ishida (2002), when discussing the origin of the pelagic carbonates and chert successions included in the accretionary complexes of the Japanese Islands, placed the oceanic Isanami Plateau at low-latitudes on the Izanagi Plate, having in view the Tethyan low-latitude confinement of the conodont $C h$. timorensis occurrences. Kiliç et al. (2015) stated that environmental stress factors, among them thermal and trophic, caused decrease in size and morphological complexity of the conodonts during the Triassic. This may justify also the low-latitude confinement of the condont Ch. timorensis, as already stated by Hirsch \& Ishida (2002).

Klets (2008, tab. 4) placed the occurrence of the Chiosella timorensis/gondolelloides group in the TethysPanthalassa super-realm, this including the southwestern 

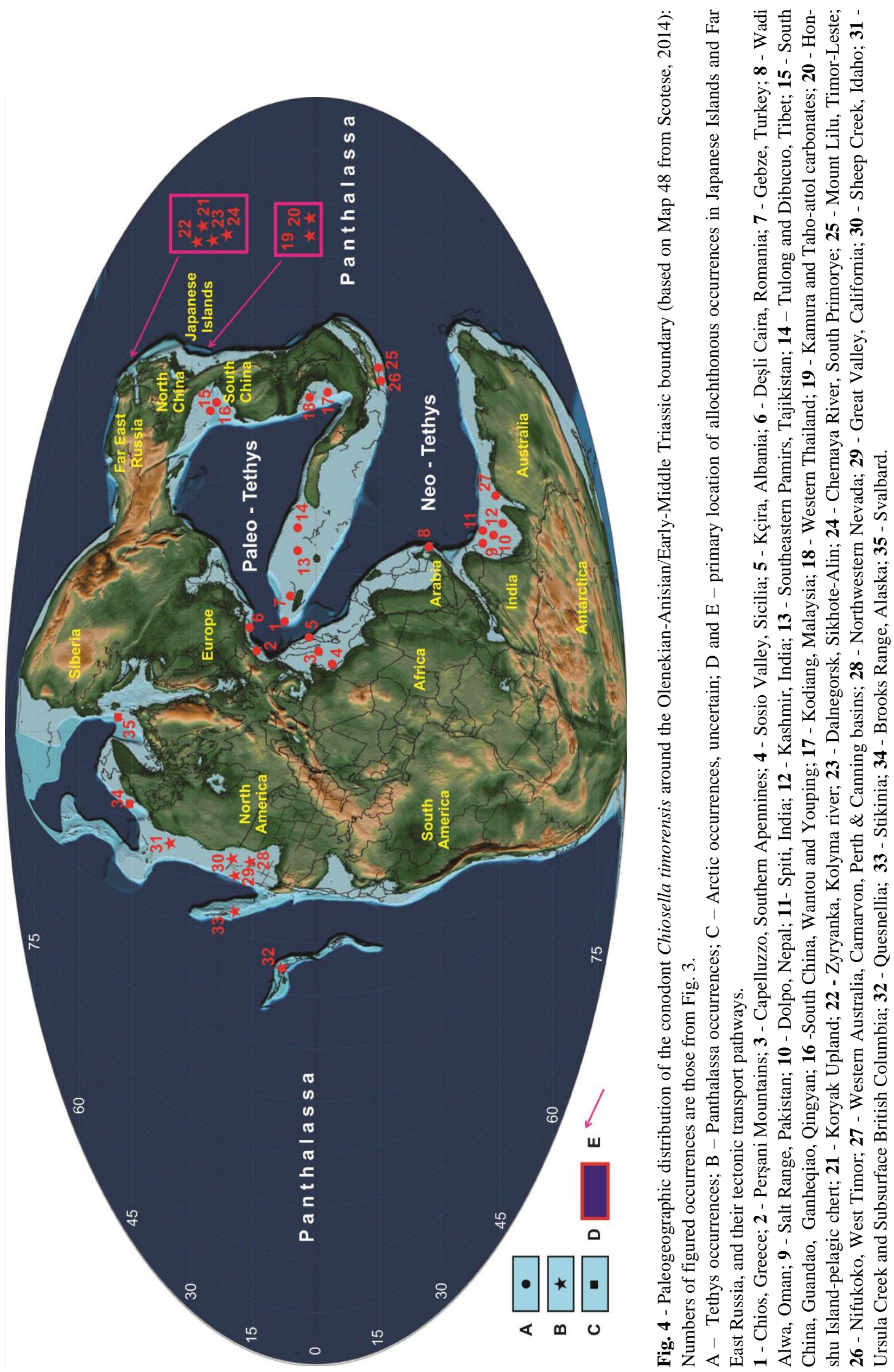
United States, Greece, Japan, western Pakistan, India, Timor Island and China. With regard to Neospathodus (= Chiosella) aff. timorensis, subsequently described as $C h$. omulyovika Kopylova and Klets, 2008, which was reported in the Zyryanka River Basin, Kolyma region by Klets \& Kopylova (2008) and Konstatinov \& Klets (2009), and placed in the Panboreal super-realm by Klets (2008), this is occurring in an allochthonous terrane that originated from low-latitudes in western Panthalassa. It must be noted, from Klets (2008) paleogeographic synthesis several occurrences of Chiosella timorensis are missing, such as those from Western Australia, Southeast Asia, or from Europe (Capelluzzo and Sosio, in Italy, Kçira, in Albania, and Deşli Caira, in Romania).

Chen Y-L et al. (2016) discussed Triassic conodont provincialism but without any reference to Chiosella timorensis.

As may be seen from the Fig. 4, the genuine occurrences of the conodont species timorensis are confined during the Triassic within a region lying between the lowlatitudes, eventually mid-latitudes, of the northern and southern hemispheres, starting from East Panthalassa until Western Tethys. Other known occurrences in the present-day high-latitudes of North America and Europe, also in Arctic Siberia and Far East Russia, are either unconfirmed or doubtful, or are in allochthonous terranes that were tectonically transported from low-latitudes to their present-day high-latitudes.

One may conclude, the conodont species timorensis cannot be used for dating and global correlation of the Triassic successions in regions outside the Tethys domain and Panthalassa. The distribution of other associated groups of fossils clearly demonstrates there existed a latitudinal paleoclimatic control in the distribution of the conodont species timorensis. On the other side, even in the Tethyan domain the distribution of the conodont species timorensis was facies controlled, and this may explain the diachronism of its first occurrence.

\section{The GSSP candidates for the base of the Anisian, hav- ing the conodont Chiosella timorensis as a defunct primary biotic proxy}

Following the recommendation of the International Commission of Stratigraphy to document the GSSP candidates for the standard chronostratigraphic units by significant biotic and physical events (see Gradstein et al., 2004, 2012, 2020; Lucas, 2018a), a plethora of articles has been focused on the biotic and physical events around the Olenekian-Anisian/Early-Middle Triassic boundary.

As for the biotic events, the conodont biostratigraphy received particular attention, with the desire to find suitable conodont taxa to be designated as biotic proxies for the Triassic standard chronostratigraphic boundaries. In the case of the base Aegean/lower Anisian/Middle Triassic boundary, after the early proposal made by Sweet (1970a) to introduce a Timorensis conodont zone although controversial with regard to the dating of the FO of the conodont species timorensis, Nicora (1977) and Assereto et al. (1980) made for the first time the formal proposal that the FAD of the conodont Gondolella timorensis Nogami, 1968 be used for the definition of the lower boundary of the Anisian in the Chios section, in Greece. However, Gaetani et al. (1992) underlined that in the Chios section the FAD of timorensis precedes the Aegean ammonoid FAD, and concluded that if the boundary is drawn on the base of ammonoids, timorensis FAD is latest Spathian in age. On this basis, Jacobshagen et al. (1993) concluded that the conodont argument of Assereto et al. (1980) should not be proposed as a biotic proxy for the base of the Anisian. During the Halle meeting of the STS (1998), it was decided to abandon the proposal made by Muttoni et al. (1994) of the Chios section as a GSSP candidate (cf. Gaetani, 2000).

Subsequently, Deşli Caira (Dobrogea, Romania) and Guandao (Guizhou Province, South China) have been formally nominated as GSSP candidates for the definition of the Early-Middle Triassic boundary by the International Commission on Stratigraphy, 2004, having as primary markers the near lowest occurrences of the ammonite genera Japonites, Paradanubites, and Paracrochordiceras, and of the conodont Chiosella timorensis, as primary markers, the proposed level being slightly below the base of a normal polarity magnetic zone (see Ogg, 2004), Subsequently, the Deşli Caira section became the first-ranked GSSP candidate, to which the Guandao and South Primorye sections are added as significant GSSP sections in the Geological Time Scale of the Triassic System, with the FAD of the conodont Chiosella timorensis or the base of magnetic normal polarity chronozone MT1n as correlation events (see Gradstein et al., 2012, 2020; Ogg et al., 2014, 2016). It must be noted, nevertheless, that the conodont species timorensis is absent in the South Primorye section (see Zakharov et al., 2005a-b).

In China, besides the Guandao section, promoted by Lehrmann et al. (2002, 2015a-b) and Orchard et al. (2007b), other localities in Guizhou Province, South China, e.g., Ganheqiao and Qingyan (Yao et al., 2011), Wantou and Youping (Ogg, 2019; Chen Y et al., 2020; Ogg et al., 2020a-b) have been credited as potential GSSPs for the base of the Anisian. However, in the Guandao section the Olenekian-Anisian boundary is not demonstrated by an ammonoid record, as was recently noted once more by Tong et al. (2019). Like the Guandao section, all other Chinese sections recently proposed as potential GSSPs are also devoid of diagnostic ammonoids to fix the Olenekian-Anisian/Early-Middle Triassic boundary (see Yao et al., 2011, and Chen Y et al., 2020). In none of the Chinese sections the conodont biochronology and the FAD of the conodont species timorensis are not confidently tied to the ammonoid biostratigraphy around the Olenekian-Anisian/Early-Middle Triassic boundary, as ammonoid faunas are missing just in the interval boundary. Moreover, it must be underlined that the timorensis definition and the timorensis versus gondolelloides status in the Chinese publications are at odds with the current 
opinions of Goudemand et al. (2012). Although the data from Nevada clearly document the FAD of timorensis is in the latest Spathian (Goudemand et al., 2012), the Chinese conodont workers still continue to pay credit to this conodont species as a primary biotic proxy for the OAB, and for this they are questioning even the adequacy of the ammonoid biostratigraphy to define this boundary. Tong et al. (2019, p. 9), amazingly, even questioned if the ammonoid Neopopanoceras haugi zone belongs to the late Spathian or rather to the early Anisian. This is only repeating an old, untenable assertion by Assereto et al. (1980) and Fantini Sestini (1981), as already shown above.

In spite of the undeniable data regarding the latest Spathian FAD of the conodont Chiosella timorensis, as fairly documented by Goudemand et al. (2012) and Ovtcharova et al. (2015), some authors (e.g., Ogg, in Gradstein et al., 2012; Lehrmann et al., 2015a-b) still obsessively advocate that this conodont could be used as an index for the Olenekian-Anisian/Early-Middle Triassic boundary.

Recently, other authors like Yan et al. (2015), Liang et al. (2016), Bai et al. (2017), Li M et al. (2018b), Muto et al. (2018, 2019, 2020), Muto (2021), Zhang L et al. (2019a), Song et al. (2021) and $\mathrm{Ha}$ et al. (2021) continue to give credit to the conodont $C h$. timorensis as a primary biotic index for the Olenekian-Anisian/Early-Middle Triassic boundary, in spite of the firm evidence that the FAD of Ch. timorensis is in the latest Spathian, as Goudemand et al. (2012) and Ovtcharova et al. (2015) already demonstrated.

Moreover, Orchard (2016) and Ogg et al. (2016, 2020ab), minimizing that the standard chronostratigraphic units in the Triassic timescale are primarily defined on ammonoid biostratigraphy, and not on conodont biostratigraphy, repetitively recommended that the ammonoid Neopopanoceras haugi Zone should be assigned to the Anisian, and this only with the desire to support furthermore the conodont Chiosella timorensis as a proxy for the Olenekian-Anisian boundary. The mentioned authors ignore that the ammonoid Haugi Zone is followed by the ammonoid Stevensi Zone in the latest Spathian of the western USA (Monnet et al., 2013), and that both zones are correlatable to the late Spathian ammonoid Subrobustus Zone in the high-latitude Triassic chronostratigraphy in North America, Svalbard and Siberia.

Lastly, Muttoni et al. (2019) claimed the Kçira-A section in Albania has "excellent" potential as a candidate Global Boundary Stratotype Section and Point (GSSP) for the Olenekian-Anisian boundary (OAB), once again based on the FO of Chiosella timorensis. As already shown in the present paper, the GSSP candidate of the Albanian KçiraA section is inadequate with regard to the ammonoidconodont record around the Olenekian-Anisian boundary. As regards the chronostratigraphic significance of the FAD of Chiosella timorensis (= Gondolella timorensis Nogami, 1968), it was shown in the previous sections of the present paper that it has been for a long time influenced by the fact that the stratigraphic record of this co- nodont was not properly tied to or was misinterpreted with respect to the ammonoid biostratigraphy around the Olenekian-Anisian/Early-Middle Triassic boundary, and also by its disputable taxonomic interpretation.

The new acquired data on the ammonoid biochronology around the Olenekian-Anisian boundary in the lowlatitude Triassic regions, such as in western United States (Bucher, 1989; Guex et al., 2010), North Dobrogea, Romania (Grădinaru \& Gaetani, 2019) and the North Caucasus, Russia (Shevyrev, 1995, 1996), may help to clarify the yet unresolved problems of the conodont biochronology around this boundary.

The recent refinement of the bed-by-bed ammonoid succession in the Deşli Caira section (Grădinaru, in Grădinaru \& Gaetani 2019, fig. 2) clearly documents that the Olenekian-Anisian boundary is higher than was previously indicated by Grădinaru et al. (2002, 2006, 2007) and Grădinaru \& Sobolev (2006). Based on the newlyacquired ammonoid data, the base Aegean is characterized by the FADs of the ammonoid genera Paracrochordiceras, Aegeiceras, Japonites, Stenopopanoceras and Grambergia, and other lower Anisian ammonoids. In particular, the new ammonoid record in the Deșli Caira section shows that the cladiscitids, whose chronostratigraphic location in the Chios section was not yet clear to Assereto et al. (1980) and Fantini-Sestini (1981), and on which these authors prompted their untenable assertions on the base of the Anisian, occur well below the Olenekian-Anisian boundary. As a result, the FAD of the conodont Chiosella timorensis in the Deşli Caira section is now well located below the presently ammonoiddocumented Olenekian-Anisian boundary (Fig. 5).

Golding (2021a), having in view the new ammonoid data in the Deşli Caira section that relocates the position of the Olenekian-Anisian boundary in this section (Grădinaru, in Grădinaru \& Gaetani, 2019), re-examined the conodont taxonomy and biostratigraphy in the Deşli Caira section, Romania, which is the primary-ranked GSSP for OAB. He nominated new conodont taxa as potential biotic tools to be used in the recognition and correlation of the base of the Anisian Stage/Middle Triassic Series and having potential for more refined correlation of the lower Anisian between North America and Tethys.

In conclusion, the Deşli Caira section, which shares a very good potential for an adequate ammonoid-conodont biostratigraphy, preserves its first-ranked position as a GSSP candidate for the Olenekian/Anisian boundary, and thus for the Early Triassic/Middle Triassic boundary. The lowest occurrence (LO) of the ParacrochordicerasAegeiceras ammonoid assemblage deserves to be a primary biotic event to define the base of the Anisian, whilst the LOs of the conodont species Neogondolella curva, Golding, 2012 and N. gradinarui, Golding, 2021 may be auxiliary biotic events to identify the base of the Anisian. 


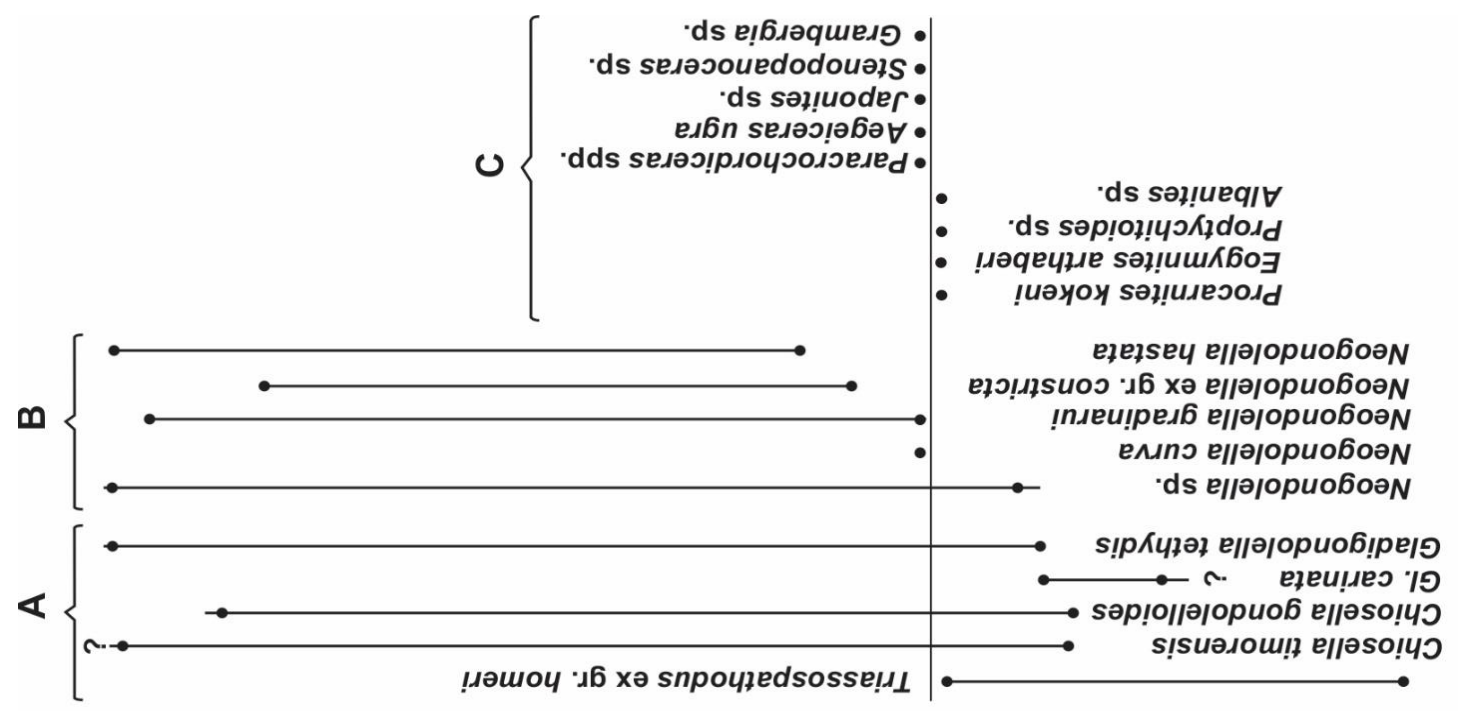

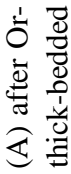

해융

응

.

도

응.

ن

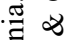

हี

ㄷ․

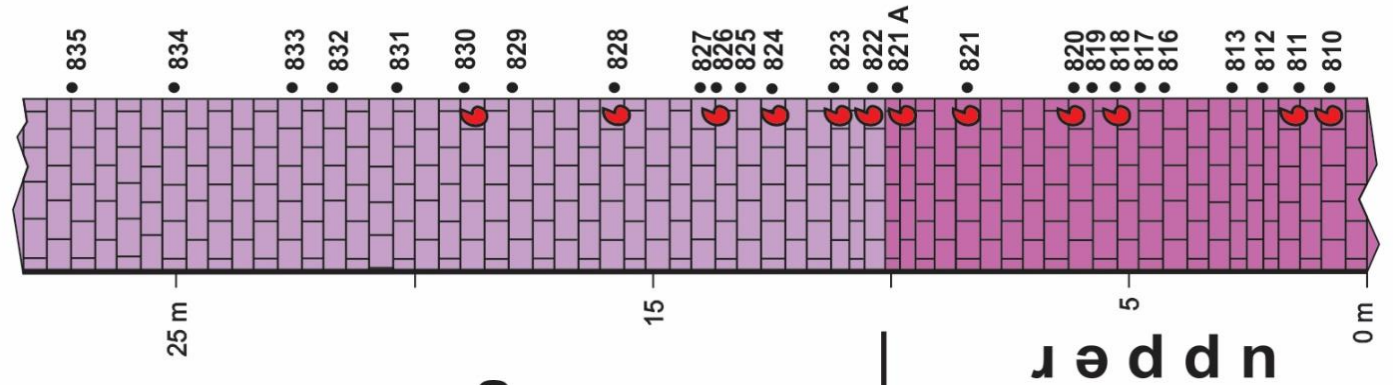

u e
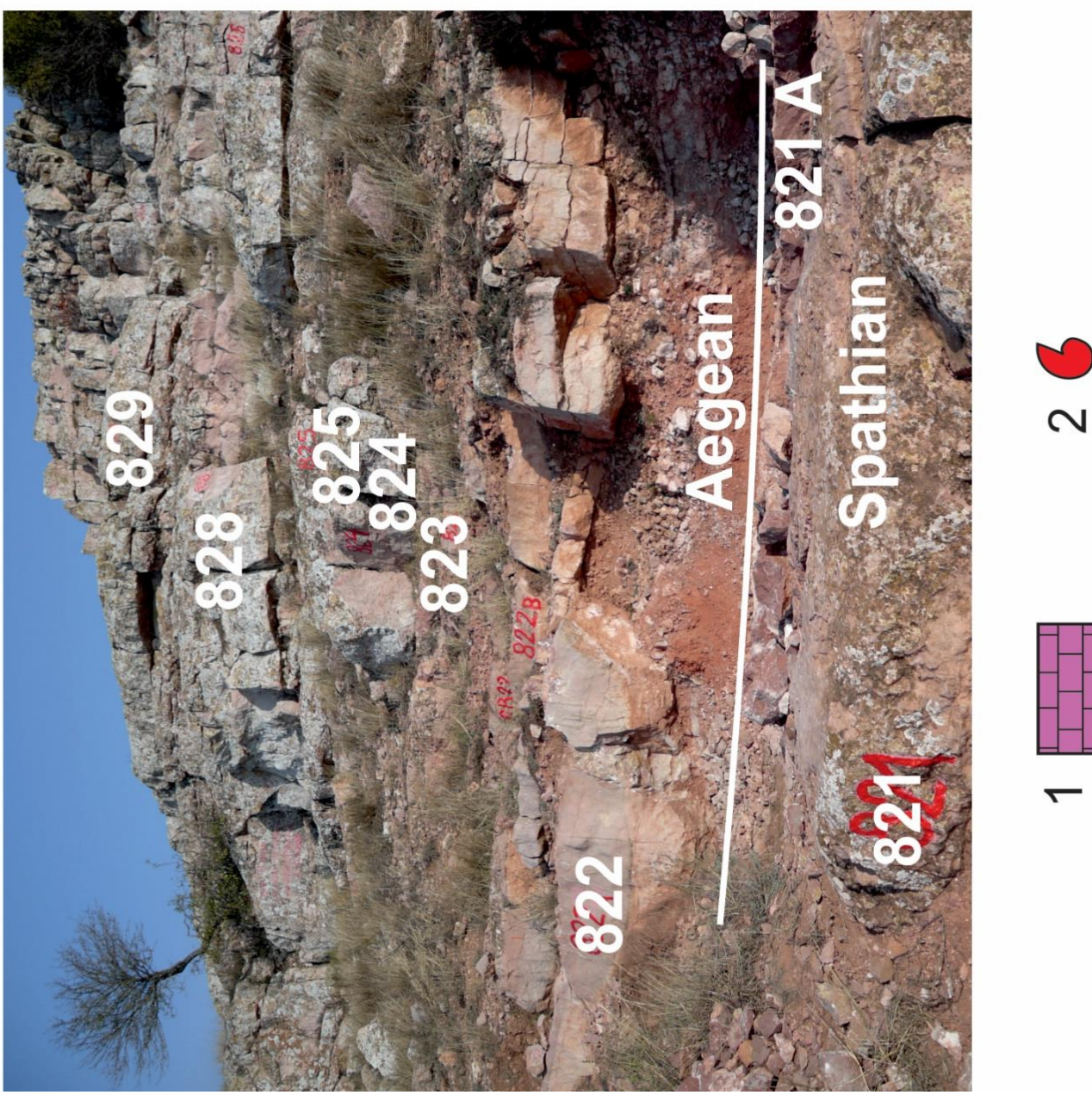

N

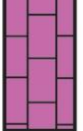




\section{THE POTENTIAL OF CONODONTS FOR CHRONOSTRATIGRAPHIC CALIBRATION OF THE AMMONOID-BASED TRIASSIC TIME- SCALE}

Huckriede (1958) and Mosher (1968), outstanding pioneers of the Triassic conodont studies, early suggested that the conodonts, in the absence of diagnostic ammonoids, may assist in the classification of the Triassic, but cannot replace the ammonoids, which are standard stratigraphic index fossils in the Triassic. The first step into the Triassic conodont zonation was done by Sweet (1970a), who divided the uppermost Permian to Lower Triassic rocks of the Salt Range and Trans-Indus ranges into a sequence of nine conodont zones. Sweet (1970b) stated that the study of the distribution of conodonts in connection with that of other fossils, particularly ammonoids, should yield a highly refined biostratigraphy of the Triassic. Sweet et al. (1971) expanded the Triassic conodont biostratigraphy to a sequence of 22 faunal assemblages, which were correlated to the North American ammonoid zonation done by Silberling \& Tozer (1968). Subsequently, Kozur \& Mostler (1972), Budurov (1976ab) and especially Kozur (2003a, b, and his previous references therein) contributed to build the Triassic conodont zonation in the Tethyan and Germanic successions. Orchard \& Tozer (1997a-b) presented a refined conodont biochronology for the Triassic of the Western Canada Sedimentay Basin. The authors intercalibrated the conodont scale with ammonoid zones and standard Triassic stages, with the desire to produce a continental conodont standard with good potential for global application.

Orchard (2010) noted the conodonts, although these arrived late on the stage of early Mesozoic timescale definition, have become increasingly important in helping to define the Global Stratotype Sections and Points (GSSPs) of Triassic stages, and have competed with traditional Triassic ammonoid indices. The key conodont taxa for the Triassic boundary definition, the conodont zones and ranges are summarized by Orchard (2010), with reference to the ammonoid zones in significant sections from $\mathrm{Eu}-$ rope, Himalayas, China and North America. Orchard (2010) underlined that there is no denying the pivotal role of ammonoids in Triassic timescale studies but stressed the conodonts benefit from their greater abundance, widespread distribution, and great resilience.

Chen Y-L et al. (2016) portrayed the correlation between conodont and ammonoid zones and the conodont stratigraphic distribution in the middle and early Late Triassic stratigraphic interval. Klets (2006) summarized Triassic conodont zones and their stratigraphic distribution in the Arctic regions of Russia and the Northwest Pacific regions, including Far East Russia and Japan. Besides the above mentioned major references there is an abundant literature that is focused on the conodont key taxa with assumed potential in defining various boundaries in the standard Triassic timescale, and on the conodont zonation and stratigraphic ranges in specific intervals of the Triassic.

From the beginning, it must be emphasized that historically the conodonts have had no contribution to building the standard Triassic timescale, except for their recent involvement in redrawing the base of the Triassic System, if this could be really qualified as a real contribution, and thus, in principle, the conodonts are not qualified to contribute to the building or rebuilding of the standard Triassic timescale. It seems that many Triassic conodont workers ignore that the Triassic chronostratigraphy, with its actual standard units, series, stages and substages, is primarily defined and calibrated on ammonoid biostratigraphy developed over two centuries in Europe and North America, with the most important development after the middle of the twentieth century (Tozer, 1965, 1967, 1971, 1984, 1994a; Silberling \& Tozer, 1968; Silberling \& Nichols, 1982; Shevyrev, 1986, 1995, 2006; Bucher, 1988, 1989, 1992, 2002; Mietto \& Manfrin, 1995; Krystyn et al., 2004; Monnet \& Bucher, 2005, 2006; Lucas, 2010, 2013, 2018c; Balini et al., 2010; Jenks et al., 2015). In the successive editions of The Geological Time Scale published by Gradstein et al. $(2004,2012,2020)$ is clearly stated that the ammonoid successions have basicaly served as global primary standards for the Triassic System. Consequently, although there is an insistent desire to promote other biotic and physical events as proxies, the ammonoid biochronology is first ranked in the calibration of the Triassic Time Scale, to which all other biotic and physical events are calibrated (see Ogg et al., 2020b, Figs. 25.5 to 25.7).

The Triassic conodonts, besides other microfossil groups, may serve as useful tools for rock dating and stratigraphic correlation, but their biostratigraphy must be properly tied to a solid ammonoid-based Triassic timescale. Discussing this matter, Lucas (2013) rejected conodont biostratigraphy as a basis for defining Triassic chronostratigraphic units and advocated using ammonoid biochronological events to define all Triassic stage boundaries, so as to ensure the stability of the Triassic timescale. In line with the above statements, Lucas (2020a) has extended his criticism of the use of conodonts as a primary signal also for Carboniferous GSSPs instead of foraminiferal (especially fusulinid) and ammonoid biostratigraphy, upon which Carboniferous chronostratigraphic definitions have historically been based.

Lastly, it must be noted that some authors, e.g., Li M et al. (2018b, fig.7), are using the conodont biostratigraphy versus magnetic polarity patterns in the Guandao section like the bellows of an accordion to play with the substage boundaries within the Middle Triassic Series, to the definition of which neither the conodonts nor the magnetostratigraphy have had a primary contribution.

In the Albertiana Forum, Lucas (2016) listed five reasons for which the Triassic conodonts, the extensive study of which did not begin until the 1970s, are not inherently superior tools with which to define the Triassic chronos- 
tratigraphy. Among them two reasons are especially significant: (1) the relative youth of Triassic conodont taxonomy, which remains still unstable for many taxa; and (2) the youth of stratigraphic studies of Triassic conodonts, so that many conodonts do not yet have wellestablished stratigraphic ranges. I add to these the observation that conodont biostratigraphy is still not properly tied to the ammonoid biostratigraphy in the stratigraphic successions of most of the Triassic chronostratigraphic boundaries. This is just the case of the OlenekianAnisian/Early-Middle boundary, here discussed, and there are many other boundaries in the same situation in the Triassic timescale.

In his reply to Lucas' comments, Orchard (2016), although arguing for an integrated ammonoid-conodont biostratigraphy, claimed, however, with the desire to support the advantage of the conodont study, "that the careful preparation of ammonoids in the laboratory is often necessary prior to precise determination". On the contrary, it must be noted this assertion is especially true for the conodonts, which require lengthy and costly laboratory extraction procedures before their taxonomic identification, in contrast to the easy identification of ammonoids, at least at the genus level, even during fieldwork. Of course, this needs adequate expertise in Triassic ammonoid taxonomy. For the conodont studies, it is enough to sample a rock succession, and this does not necessarily need exploration for ammonoids in the field. Unfortunately, as Lucas (2013, 2016) noted, the retirement in the 1990s of many of the Triassic ammonoid workers fueled the use of the conodonts as the main tools to define, and, unfortunately, in some cases, even to alter, many of the Triassic chronostratigraphic boundaries. As already documented by the four-decades of relentless studies on the Olenekian-Anisian/Early-Middle Triassic boundary, the conodonts could not replace the ammonoids in the definition of this boundary, to which only the ammonoids have contributed.

To exemplify the involvement of the conodonts in redrawing the ammonoid-based Triassic timescale, the best example is the use of the conodonts for altering the scope of the Griesbachian Stage, as this has been primarily defined by Tozer $(1965,1967)$, and the involvement of conodont biochronology, to the detriment of the ammonoid biochronology, in the defining the base of the Triassic System.

When the Meishan section, Changxing County in Zhejiang Province of South China, was adopted by the International Commission on Stratigraphy as the Global Stratotype Section and Point (GSSP) of PTB, with the base of the conodont Hindeodus parvus horizon at the Bed 27c marking the Permian-Triassic boundary, Yin et al. (2001) stated that the Otoceras-bearing strata should be subdivided into two beds. Accordingly, the Lower Otoceras Bed, containing only $O$. concavum and its equivalents Hypophiceras (triviale, martini and changxingense), is latest Permian in age, whereas the Upper Otoceras Bed, containing latilobatum, woodwardi and boreale, mainly corresponds to the base Triassic Parvus Zone. As a consequence, by favouring the conodont biochronology, to the detriment of the ammonoid biochronology, Yin et al. (2001) stated that the original Griesbachian Stage, the base of which was originally defined by the FAD of Otoceras concavum, spans the uppermost Permian and the lowest Triassic. So, in the formal GSSP proposal of Yin et al. (2001) to define the PTB, the truncated 'Griesbachian' is used to represent the 'Lower Induan', and by this the base of the truncated 'Induan' Stage, without the Lower Otoceras Bed, should be defined by the FAD of the conodont species parvus rather than the ammonoid Otoceras.

Particularly, at the Meishan GSSP, the PTB is placed in the mid of the Bed 27, arbitrarily split into four parts, each only $0.04 \mathrm{~m}$ thick, lacking any physical evidence of a major catastrophic event that it is believed to have happened at the end-Permian, to which one of the most severe biotic crises is currently allocated (e.g., Clapham, 2021; Racki, 2021).

Bjerager et al. (2006), based on the study of the ammonoid stratigraphy in the classical region of East Greenland, emphasized that the correlation of the ammonoid stratigraphy with the FAD of Hindeodus parvus, which defines the base of the Triassic in Global Stratotype Section and Point in Meishan, is no longer reflecting major changes in the Earth system. As a consequence, Bjerager et al. (2006) concluded that it would have been fortunate if a Permian-Triassic GSSP were defined in a protracted section at a point of major environmental perturbations, marked by isotope excursions, chemical anomalies and mass extinction, rather than in the strongly condensed section like Meishan, at a point which post-dates all significant events prior to the beginning of the Triassic.

Brühwiler et al. (2008) stated that at Meishan, where the Permian/Triassic boundary has been defined on the basis of the FAD of the conodont species Hindeodus parvus, parts of the lower Griesbachian Otoceras beds would fall within the Permian, a premise that was not accepted by Triassic workers (e.g., Tozer, 2003; Shevyrev, 2006). So, in describing the Early Triassic ammonoids from Southern China, Brühwiler et al. (2008, fig. 4) correctly refer to the Griesbachian Stage as defined by Tozer (1994b-c).

With regard to the suitability of conodont biochronology in defining the Permian-Triassic boundary, it is to be noted the differences in the opinions of Paull \& Paull (1994) and Orchard (1994b). Paull \& Paull (1994) claimed that the conodont Hindeodus parvus has a broad distribution in the western United States, and thus endorsed its suitability to be used as an index fossil for the PermianTriassic boundary as proposed by Yin (1993). On the contrary, Orchard (1994b) underlined there is little, if any, unambiguous conodont data that demonstrate contemporaneity of lower Griesbachian Otoceras Beds and the uppermost Changhsingian/uppermost Permian. Subsequently, the assertion of Orchard (1994a) is reconfirmed in the Triassic conodont biochronology done by Orchard \& Tozer (1997a-b) for the Western Canada Sed- 
imentary Basin, where the conodont Hindeodus parvus is absent. Ultimately, Orchard (2010) accepted, however, the conodont Hindeodus parvus as the primary biotic proxy for the PTB.

Amazingly, although the lower part of the Griesbachian Stage as primarily defined is now placed in the uppermost Permian, by designating the conodont species Hindeodus parvus as a primary biotic proxy for the Permian-Triassic boundary at Meishan in Zhejiang Province, China (Yin et al., 2001; Jiang et al., 2007), the truncated 'Griesbachian' Substage of the truncated 'Induan' Stage has not yet been formally redefined and based on a new stratotype, as was hinted by Baud \& Beauchamp (2001) and Baud (2001). It is denoted as ' $u$. Griesbachian (Gangetian)' in the Geologic Time Scale 2012, while subsequently Ogg et al. (2016) and Gradstein et al. (2020, fig. 25.7) and many other authors (e.g., Wignall \& Twitchett, 2002; Jiang et al., 2007; Algeo et al., 2008, 2013; Algeo \& Twitchett, 2010; Wignall et al., 2010; Bond \& Wignall, 2010; Hounslow \& Muttoni, 2010; Orchard, 2010; Nielsen et al., 2010; Joachimski et al., 2012, 2019; Schoepfer et al., 2013; Burgess et al., 2014; Shen et al., 2015, 2021; Lehrmann et al., 2015a-b; Brosse et al., 2015, 2017; Li F et al., 2013, 2015, 2017, 2019; Liang et al., 2016; Wu S et al., 2017; Brayard et al., 2017; Bai et al., 2017, 2021; Huang, 2018; Li M et al., 2018a; Zhang F et al., 2018; Zhang L J et al., 2018; Foster et al., 2019; Zhang L et al., 2019a-b; Wu K et al., 2019; Wu H-T et al., 2019; Kutygin et al., 2019; Biswas et al., 2020; Brian et al., 2020; Luo et al., 2020; Chen J et al., 2020; Kelley et al., 2020; Zuchuat et al., 2020; Song et al., 2013, 2018, 2021; Clapham, 2021; Du et al., 2021; Sun et al., 2021; Brookfield et al., 2021) continue to refer to the Griesbachian Substage or to the Induan Stage as if nothing happened.

When Wei et al. (2020) refer to the lower and middle 'Griesbachian' they do not mention that the 'Griesbachian' in their meaning is not equivalent to the primary Griesbachian Stage as defined by Tozer (1965, 1967). It is also the case of Chen J et al. (2019), who are referring to the early and late 'Griebachian' as divisions of the truncated 'Griesbachian' Substage.

An even more strange interpretation and alteration of the original Griesbachian Stage is given by Liu $\mathrm{X}$ et al. (2020), who define a PTB interval, the base of which is marked by the FO of the conodont Hindeodus parvus, and a 'Late Griesbachian', the base of which is marked by the FO of the conodont Isarcicella isarcica. Should we understand that the PTB interval corresponds to the 'Early Griesbachian'? And, to which Griesbachian, the truncated 'Griesbachian'? In any case, it is not referring to the Griesbachian Stage as originally defined by Tozer $(1965,1967)$. This is one of the clearest examples of the abusive involvement of conodonts in redrawing the standard Triassic chronostratigraphic scale, as it was founded by ammonoid biostratigraphy. Baud (2014), although he was among the STS officials who assisted at the unveilling ceremony of the PTB GSSP at Meishan, after reviewing the history and controversies related to the global marine Permian-Triassic boundary, concluded that the actual Meishan highly condensed GSSP section is untenable, and a new locality for the PTB GSSP should come in the near future. However, this has not happened yet.

Lucas (2019), discussing the case of the Meishan GSSP for base of the Triassic System, underlined that in the last years it has become clear that the LO of Hindeodus par$v u s$ at Meishan is not its stratigraphically lowest (oldest record), as older records of this conodont species are known elsewhere in southern China, and concluded this should prompt a revision of the base Induan GSSP.

On the other side, there are many recently published articles where the term Griesbachian is ignored in the chronostratigraphy, only the term Induan is used, indeed the truncated 'Induan', but this doesn't overcome the complications introduced in the definition of the PTB by involving the conodont biochronology.

Concluding, one may see that the involvement of the conodont biochronology, having a short history in its construction, to the detriment of the long history of contribution of ammonoid biochronology in building the standard Triassic timescale, has generated great complications and misunderstandings in the definition of the base of the Triassic System. As the beginning of the primary Griesbachian Stage/Substage predates the conodontbased GSSP for the beginning of Triassic time, Lucas (2013) noted this requires moving the base of the Triassic downward, back to its pre-conodont defined base. This means to come back to the Griesbachian Stage as primarily defined by Tozer $(1965,1967,1994)$ in the Arctic Canada. The primarily defined Griesbachian is used as such by Dagys \& Weitschat (1993), Dagys \& Ermakova (1996), Zakharov et al. (2020), Bjerager et al. (2006) and Jenks et al. (2021) in the Induan chronostratigraphy from Verkhoyansk Basin (Siberia), East Greenland and western USA Basin.

Another example of how the conodonts are preferentially used in redrawing the Triassic time scale, to the detriment of ammonoid biostratigraphy, particularly with regard to the Norian-Rhaetian stage boundary, is the case of the Sevatian Substage, traditionally the last substage of the Norian Stage (e.g., Zapfe, 1974; Krystyn, 1980, 1988, 1990, 1991; Golebiowski, 1990). Based on the ammonoid biostratigraphy, the primary Sevatian Substage is divided into two parts, the lower part (= Sevatian 1) defined by the co-occurrence of the ammonoids Metasibirites spinescens and Sagenites quinquepunctatus, and the upper part (= Sevatian 2) defined by the co-occurrence of the ammonoids Paracochloceras suessi and Sagenites reticulatus. Subsequently, Krystyn \& Kuerschner (2005), Krystyn et al. (2007c), Krystyn (2008 a-b), Maslo (2008) and McRoberts et al. (2008), based on the co-occurrence of boundary-specific ammonoids and conodonts in sequence, proposed two alternative conodont proxies for the base of the Rhaetian Stage. Having the FAD of the conodont species Misikella hernsteini as the $1^{\text {st }}$ proxy 
option, the upper Sevatian (= Sevatian 2 ) is placed in the Rhaetian, whilst the lower Sevatian (= Sevatian 1) is left at the top of the Norian. The $2^{\text {nd }}$ proxy option, the FAD of the conodont species Misikella posthernsteini, following the decision of the STS Task Group on the placement of the GSSP for the Norian-Rhaetian stage boundary (see Krystyn, 2010), has been formally recommended to fix the base of the Rhaetian Stage. Consequently, by adopting the STS proposal, the Rhaetian Stage is starting with the base-truncated upper Sevatian, i.e., the base truncated Sevatian 2 (e.g., Krystyn, 2010; Giordano et al., 2010; Hounslow \& Muttoni, 2010; Muttoni et al., 2010; Rigo et al., 2015; Maron et al., 2015; Krystyn et al., 2015; Bertinelli et al., 2016; Galbrun et al., 2020). A $3^{\text {rd }}$ proxy option for the base of the Rhaetian, designated by Krystyn et al. (2007d), is the ammonoid Vandaites stuerzenbaumi, the FO of which is concurrent with the FO of the cosmopolitan bivalve Otapiria, and also coincident to a distinct turnover in the pollen and spores and marine palynomorphs. However, this $3^{\text {rd }}$ option, which marks the base of the classic ammonoid-based Rhaetian (Krystyn, 1980, 1988, 1990, 1991; Golebiowski, 1990) is disqualified on the reason that no changes in conodonts are known with the $3^{\text {rd }}$ option, and also because it stands distinctly above the STS recommended boundary and a correlation with the magnetostratigraphy is also not established (Krystyn et al., 2007d, p. 171).

With regard to the conodont Misikella posthernsteini, it must be noted that there are two diverging taxonomic interpretations of this taxon occurring in the Steinbergkogel (Austria) section and the Pignola-Abriola (Italy) section, respectively, both sections being competing candidates for the Rhaetian GSSP. These two diverging interpretations are designated as $M$. posthernsteini morphotype A, or M. posthernsteini sensu lato, for the Austrian GSSP candidate, and as M. posthernsteini morphotype B, or M. posthernsteini sensu stricto, for the Italian GSSP candidate (see Galbrun et al., 2020 and Ogg et al., 2020b, and references therein). In the Austrian section the two morphotypes are separted only by one bed (Galbrun et al., 2020). It must be noted, the discrimination of the two morphotypes remains an exciting exercise for the Triassic conodont workers, but this does not fulfill the practical requirements for a biotic proxy, i.e., to be easily identifiable in rock successions. Bertinelli et al. (2016) claimed that the FAD of $M$. posthernsteini sensu stricto is the STS-voted biomarker for the definition of the Rhaetian base, although there is not any official decission for this. The Italian 'short Rhaetian', instead of the Austrian 'long Rhaetian', is preferred by Ogg et al. (2020b), because in their opinion it complies better with the Rhaetian cyclomagnetostratigraphy and with excursion in $\delta^{13} \mathrm{Corg}$.

It must be mentioned (see Grădinaru \& Sobolev, 2010, tab. 5), the Rhaetian Stage in the North American Triassic timescale, having the index ammonoid Paracochloceras amoenum at its lower part, as asserted by Orchard \& Tozer (1997a-b), Carter \& Orchard (2007), McRoberts (2010), Orchard (2010) and Taylor et al. (2021), is equiv- alent to the Rhaetian Stage in the European Alpine Triassic timescale, including in its lower part the upper Sevatian (= Sevatian 2) with the index ammonoids Paracochloceras suessi and Sagenites reticulatus, and with the FAD of the conodont species Misikella hernsteini as the $1^{\text {st }}$ proxy option to define the base of the Rhaetian Stage as proposed by Krystyn et al. (2007c).

Particularly, Orchard (2010, 2016) emphasized that in western North America the conodont Misikella is rare and does not provide a practical guide fossil for base definition of the Rhaetian Stage, thus questioning its potential for intercontinental and latitudinal correlations, respectively.

Coming back to the primary Sevatian Substage of the Norian Stage, although this is variously truncated by the different proposals to define the Norian-Rhaetian boundary, it must be noted that in many recent publications this chronostratigraphic unit is further used as if nothing happened (e.g., Ogg et al., 2020b, fig. 25.1).

Lucas (2016), relying on the new trends in discussing the base of the Rhaetian and emphasizing the complications generated by the stratigraphic range extensions and/or taxonomic problems connected with the chronomorphocline of Misikella hernsteini to Misikella posthernsteini as suggested by Giordano et al. (2010), concluded that the Triassic chronostratigraphy should abandon conodont biostratigraphy and return to the ammonoid biostratigraphy upon which the Triassic timescale was originally built.

The truncated 'Sevatian', also the truncated 'Griesbachian', both of them not complying with the primary definitions of the Griesbachian and the Sevatian stages, respectively, need formal definitions and type localities.

In spite of the numerous shortcomings generated by the involvement of the conodonts in the definition or the redefinition of the ammonoid-based Triassic chronostratigraphic boundaries, there is still great interest to promote the conodonts as primary tools for defining other Triassic chronostratigraphic boundaries. Morever, even among the conodont researchers there is no consensus with regard to the nominated conodont proxies for some boundaries. An example is the very recent proposal done by Lyu et al. (2020) to use the lineage of the conodont Eurygnathodus costatus in defining the base of the Olenekian (Lower Triassic), to the detriment of the conodont Neospathodus waageni (= Novispathodus waageni), already formally designated as a potential proxy for this boundary (cf. Tong et al., 2003, 2004a; Orchard, 2010; Lyu et al., 2018, 2021; Ogg et al., 2020b). Instead, Zhao et al. (2007) proposed the FAD of Novispathodus waageni eowaageni to define the Induan-Olenekian boundary, which is lower than the FO of $N v$. waageni in the West Pingdingshan section, Chaohu, South China. In addition to this, in the definition of the IOB there are yet unresolved problems with regard to the ammonoid/conodont biochronology around the boundary (e.g., Zakharov, 2004; Zakharov et al., 2000, 2009 and references therein; Tong et al., 2003, 
2004b; Krystyn et al., 2007a-b; Chinese Triassic Working Group, 2007; Orchard, 2010; Ogg et al., 2020b).

With regard to the physical events (magnetostratigraphy, chemostratigraphy, astrochronology, etc.) that have been chronostratigraphically tied to the FAD of the conodont Chiosella timorensis (e.g., Muttoni et al., 1994, 1995, 1996, 1998, 2019; Atudorei \& Baud, 1997; Atudorei, 1999; Atudorei et al., 2002; Hounslow \& McIntosh, 2003; Grădinaru et al., 2007; Galfetti et al., 2007; Horacek et al., 2007, 2009; Hounslow et al., 2007, 2008; Hounslow \& Muttoni, 2010; Burgess et al., 2014; Lehrmann et al., 2015a-b; Li M et al., 2018b; Haq, 2018; Huang, 2018; Maron et al., 2019; Zhang L et al., 2019a-b; Ogg, 2019; Chen Y et al., 2020; Ogg et al., 2020b; Ha et al., 2019, 2021), for which now there are firm data proving that this conodont is a defunct proxy for the Olenekian-Anisian/Early-Middle Triassic boundary, all of them must be chronostratigraphically re-calibrated. All of them have to be tied to the new OAB, based on the newly acquired ammonoid/conodont biochronolgy in the Deşli Caira section, North Dobrogea, Romania (Grădinaru, in Grădinaru \& Gaetani, 2019; Golding, 2021a). Thus, the excursions of all physical events around the Olenekian-Anisian/Early-Middle Triassic boundary, which have been previously tied to the FAD of $C h$. timorensis as a primary biotic tool for this boundary, now demonstrated to be a defunct proxy, have to be reevaluated and tied to the properly defined ammonoidbased Olenekian-Anisian boundary.

As Lucas (2018a, b) underlined, physical events, like magnetostratigraphy, carbon and oxygen isotopes curves and cyclostratigraphy, labelled as surrogates in the chronostratigraphic calibration by Hammer et al. (2019), cannot be used as independent correlation tools and always need to be tied to biostratigraphic or radioisotopic ages in order to be of value in correlation. On the other side, successfully using physical events in chronostratigraphic calibration is closely dependent on the completeness in the rock record and on adequate lithologies. Although the physical events have not, per se, a suitable potential for chronostratigraphic classification of the rock successions, these may help, however, to relate them to the major biotic turnovers corresponding to the chronostratigraphic boundaries in the Triassic timescale.

\section{CONCLUSIONS}

The proposal by Muttoni et al. (2019), according to which the Albanian Kçira-A section has "excellent" potential as a candidate Global Boundary Stratotype Section and Point (GSSP) for the Olenekian-Anisian/Early-Middle Triassic boundary (OAB/EMTB), is based on the conodont Chiosella timorensis as a primary biotic proxy for this boundary. This proposal is grounded on the non-valid chronostratigraphic interpretation of the ammonoid record in the Kçira-A section, and its root is to be found in the old, untenable interpretation of the ammonoid record around the nominated boundary in the Chios section, only with the desire to further qualify the conodont $C h$. timorensis as a proxy for the nominated boundary, and its claimed FO coincidence with a significant magnetostratigraphic event. Even in the absence of recent data on the ammonoid and conodont record around the nominated boundary in the western USA, and other regions, like North Dobrogea, in Romania, the correct interpretation of the ammonoid-conodont succession in the Albanian Kçira-A section is enough to demonstrate that the conodont Ch. timorensis is a defunct proxy for the OAB/EMTB. As a consequence, in the Fig. 1 of the present paper, showing the ammonoid, conodont and paleomagnetic record in the Albanian Kçira-A section, the assumed OlenekianAnisian boundary must be placed at a stratigraphic level higher than the HO of the iconic Spathian ammonoid Procarnites kokeni (Arthaber, 1908), with the FO of the conodont $\mathrm{Ch}$. timorensis falling well below the nominated boundary.

In spite of firm evidence, there are still conodont researchers who continue to support the defunct conodont Ch. timorensis as a primary biotic tool to fix the $\mathrm{OAB} / \mathrm{EMTB}$. All of them ignore that the chronostratigraphic boundaries in the standard Triassic timescale have been basically defined by ammonoid biostratigraphy. The Albanian Kçira-A section and also all of the Chinese sections, recently promoted as relevant GSSP candidates for the OAB/EMTB, clearly demonstrate the conodonts are not qualified to define or redefine the Triassic chronostratigraphic units and boundaries, for which this fossil group had no historical contribution.

To perfect the Triassic timescale the only way is to encourage a continuous progress in the study of the ammonoid record around all of its chronostratigraphic boundaries. This has been already successfully demonstrated in the case of the ammonoid-based defined GSSPs for the base of the Ladinian and Carnian stages. However, as may be seen on the official website of the Subcommission on Triassic Stratigraphy, following the designation by ICS of the conodont species Hindeodus parvus as a primary biotic proxy for definition of the base of the Triassic System, it is claimed that the conodont biostratigraphy has become now an important tool in Triassic chronostratigraphic definition and correlation. This is illustrated by the fact that besides the OlenekianAnisian/Early-Middle Triassic boundary, for which the conodont Chiosella timorensis is viewed as a primary biotic candidate, which is already demonstrated in the present paper to be a defunct proxy for the base Anisian, four other Triassic stage boundaries are nominated for which definitions based on conodont candidates are expected (see Ogg et al., 2020b, fig. 25.8).

The conodonts remain, as other microfossil groups, like radiolarians, forams, ostracods and palynomorphs, a useful tool for dating and stratigraphic correlation, having, however, no qualified potential to define or redefine the standard Triassic chronostratigraphic units and their boundaries, which are primarily defined on ammonoid biostratigraphy, and to which they have made no histori- 
cal contribution. Conodonts, besides other microfossil groups, may serve successfully as auxiliary tools, qualified as proxies, in chronostratigraphy, only if their biochronology can be closely tied to the ammonoid-based Triassic chronostratigraphy. Lastly, the abiotic tools, like magnetostratigraphy, chemostratigraphy, astrochronology, and others, have no intrinsic chronostratigraphic advantage in opposition to the biostratigraphy, adequately assisted by geochronology, on which the standard Triassic timescale is basically built. There is still no convincing evidence that the biotic responses are synchronous with the global changing of the physical factors, and this raises justifiable doubts that the abiotic events are suitable to be used as preferred primary tools in the chronostratigraphic calibration of the biotic-based standard Triassic timescale.

The opinions exposed by the author in the present account are not intended in any way to minimize the potential of the conodonts in the dating and correlation of the Triassic successions. To achieve and increase this potential, the biochronology of the Triassic conodonts, and of the other fossil groups, have to be closely tied to the biochronology of the ammonoids that are the primary fossil indexes on which the standard Triassic timescale is basically built. The conodonts can be used successfully as auxiliary tools, only in conjunction with the ammonoids as primary biotic tools, in Triassic chronostratigraphy. As the Triassic timescale is basically built on ammonoid biochronology, the conodonts have no potential and therefore no legitimacy to substitute for the ammonoids in any attempt to define or redefine the ammonoid-based Triassic chronostratigraphic units and their boundaries.

\section{ACKNOWLEDGEMENTS}

The present comprehensive review of the abundant literature on the Triassic conodont species timorensis that counts dozens of articles, focusing on its occurrence, taxonomic definition and stratigraphic range, many of them in not readily accessible publications, would have not been possible without the help of many colleagues, who are warmly acknowledged, as follows: Thomas Hofmann and Staff in the Library of the Geologische Bundesanstalt, Wien, Austria; Milan Sudar, Serbian Academy of Sciences and Arts, Belgrade, Serbia; Evgeny Sobolev, IPGG SB RAS, Novosibirsk, Russia; Yuri Zakharov and Galyna Buryi, Far Eastern Geological Institute RAS, Vladivostok, Russia; Shun Muto, Geological Survey of Japan, Tsukuba; Om N. Bhargava, Panjab University, India; Martyn Golding, Geological Survey of Canada, Vancouver; Yanlong Chen, Northwest University, China; Yang Zhang, China University of Geosciences; John Gorter, Eni Australia, Perth; Ana Márquez-Aliaga, University of Valencia, Spain.

Dr. Spencer Lucas (Albuquerque) is warmly thanked for the repetitive revisions that refined the manuscript and improved the English. Dr. Martyn Golding (Vancouver) is greatly thanked for the thorough review of the manuscript, and for helpful comments and suggestions.

For the Figure 3, reproduced from Chen Y et al. (2020), the author of the present article obtained the copyright through the Elsevier License Number 5170900120016.

The author acknowledges the funding by the Romanian Academy through the Grants 84/1999, 368/2001-2002 and 120/2007, and by UEFISCDI-Ministry of Education, Romania through the Grant PNCDI-II-ID-1960/20092010 .

\section{REFERENCES}

Algeo, T.J. \& Twitchett, R.J., 2010. Anomalous Early Triassic sediment fluxes due to elevated weathering rates and their biological consequences. Geology, 38(11): 1023-1026. https://doi.org/10.1130/G31203.1

Algeo, T., Shen, Y., Zhang, T., Lyons, T., Bates, S., Rowe, H. \& Nguyen, T.K.T., 2008. Association of ${ }^{34} \mathrm{~S}$-depleted pyrite layers with negative carbonate $\mathrm{d}^{13} \mathrm{C}$ excursions at the Permian-Triassic boundary: Evidence for upwelling of sulfidic deep ocean water masses. Geochemistry, Geophysics, Geosystems, 9(4): Q04025. https://doi.org/10.1029/2007GC001823

Algeo, T.J., Henderson, C.M., Tong, J., Feng, Q., Yin, H. \& Tyson, R.V., 2013. Plankton and productivity during the Permian-Triassic boundary crisis: an analysis of organic carbon fluxes. Global and Planetary Change, 105: 52-67. https://org.doi/10.1016/ j.gloplacha.2012.02.008

Assereto, R., 1974. Aegean and Bithynian: Proposal for Two New Anisian Substages. In: Zapfe, H. (ed.), Die Stratigraphie der alpin-mediterranean Trias. Schriftenreihe der Erdwissenschaftlichen Kommissionen, Österreichische Akademie der Wissenschaften, 2: 23-39.

Assereto, R., Jacobshagen, V., Kauffmann, G. \& Nicora, A., 1980. The Scythian/Anisian boundary in Chios, Greece. Rivista Italiana di Paleontologia e Stratigrafia, 85(3-4): 715-736.

Atudorei, N.-V., 1999. Constraints on the Upper Permian to Upper Triassic marine carbon isotope curve. Case studies from the Tethys. PhD Thesis, Faculty of Sciences, University of Lausanne, Switzerland. 160 pp.

Atudorei, V. \& Baud, A., 1997. Carbon isotope events during the Triassic. Albertiana, 26: 45-49.

Atudorei, V., Baud, A., Grădinaru, E., Gaetani, M., Bucher, H., Guex, J., Lucas, S. \& Shields, G., 2002. Chemostratigraphic markers at the Olenekian-Anisian boundary. STS/IGCP 467 Field Meeting, Veszprém, Hungary, 5-8 September 2002, pp. 9-10.

Balini, M., Lucas, S.G., Jenks, J.F. \& Spielmann, J.A., 2010. Triassic ammonoid biostratigraphy: an overview. In: Lucas, S.G. (ed.), The Triassic Timescale. Geological Society, London, Special Publications, 334: 221-262. https://doi.org/10.1144/SP334.10 
Balini, M. \& Krystyn, L., 1997. Middle Triassic ammonoids form Spiti Himalayas - a chance for major improvements in Tethyan Anisian subdivisions ? Albertiana, 19: 37-40.

Bai, R., Dai, X. \& Song, H., 2017. Conodont and Ammonoid Biostratigraphies around the Permian-Triassic Boundary from the Jianzishan of South China. Journal of Earth Science, 28(4): 595-613. https:/doi.org/10.1007/s12583-017-0754-4

Bai, R., Song, H., Benton, M.J. \& Tian, L., 2021. Phylogenetic classification and evolution of Early Triassic conodonts. Palaeogeography, Palaeoclimatology, Palaeoecology, 585:110731. https://doi.org/10.1016/ j.palaeo.2021.110731

Baud, A., 2001. The new GSSP, base of the Triassic: some consequences. Albertiana, 26: 6-8.

Baud, A., 2014. The global marine Permian-Triassic boundary: over a century of adventures and controversies (1880-2001). Albertiana, 42: 1-21.

Baud, A. \& Beauchamp, B., 2001. Proposals for the redefinition of the Griesbachian substage and for the base of the Triassic in the Arctic regions. In: Yan, J. \& Peng, Y. (eds.), Proceedings of the International Symposium on the Global Stratotype of the PermianTriassic Boundary and the Paleozoic-Mesozoic Events, Changxing (China), University of Geosciences Press, pp. 26-28.

Bender, H., 1970a. Der Nachweis von Unter-Anis ("Hydasp") auf der Insel Chios. Annales Géologiques des Pays Helléniques, 19(1967): 412-464.

Bender, H., 1970b. Zur Gliderung der mediterranen Trias II. Die Conodonten-chronologie der mediterranen Trias. Annales Géologiques des Pays Helléniques, 19(1967): 465-540.

Bertinelli, A., Casacci, M., Concheri, G., Gattolin, G., Godfrey, L., Katz, M.E., Maron, M., Mazza, M., Mietto, P., Muttoni, G., Rigo, M., Sprovieri, M., Stellin, F. \& Zaffani, M., 2016. The Norian/Rhaetian boundary interval at Pignola-Abriola section (southern Apennines, Italy) as a GSSP candidate for the Rhaetian stage: an update. Albertiana, 43: 5-18.

Biswas, R.K., Kaiho, K., Saito, R., Tian, L. \& Shi, Z., 2020. Terrestrial ecosystem collapse and soil erosion before the end-Permian marine extinction: Organic geochemical evidence from marine and non-marine records. Global and Planetary Change, 195: 103327. https://doi.org/10.1016/j.gloplacha.2020.103327

Bjerager, M., Seidler, L., Stemmerik, L. \& Surlyk, F., 2006. Ammonoid stratigraphy and sedimentary evolution across the Permian-Triassic boundary in East Greenland. Geological Magazine, 143(5): 635-656. https://doi.org/10.1017/S0016756806002020

Bond, D.P.G. \& Wignall, P.B., 2010. Pyrite framboid study of marine Permian-Triassic boundary sections: A complex anoxic event and its relationship to contemporaneous mass extinction. Geological Society of America Bulletin, 122(7-8): 1265-1279. https://doi.org/ 10.1130/B30042.1
Bragin, N.J., 1991. Radiolaria and Lower Mesozoic units of the Eastern USSR. Nauka, Moscow, 125 pp. [in Russian].

Bragin, N., Dronov, A. \& Raimbekov, Y., 2016. Middle Triassic radiolarians from the Southeastern Pamirs (Republic of Tajikistan). Revue de Micropaléontologie, 59(4): 297-310. http://dx.doi.org/10.1016/j.revmic. 2016.04.004

Brayard, A., Bucher, H., Escarguel, G., Fluteau, F., Bourquin, S. \& Galfetti, T., 2006. The Early Triassic ammonoid recovery: Paleoclimatic significance of diversity gradients. Palaeogeography, Palaeoclimatology, Palaeoecology, 239: 374-395. https://doi.org/10.1016/j.palaeo.2006.02.003

Brayard, A., Escarguel, G., Bucher, H. \& Brühwiler, T., 2009. Smithian and Spathian (Early Triassic) ammonoid assemblages from terranes: Paleoceanographic and paleogeographic implications. Journal of Asian Earth Sciences, 36: 420-433.

https://doi.org/10.1016/j.jseaes.2008.05.004

Brayard, A., Krumenacker, L.J., Botting, J.P., Jenks, J.F., Bylund, K.G., Fara, E., Vennin, E., Olivier, N., Goudemand, N., Saucède, T., Charbonnier, S., Romano, C., Doguzhaeva, L., Thuy, B., Hautmann, M., Stephen, D.A., Thomazo, C. \& Escarguel, G., 2017. Unexpected Early Triassic marine ecosystem and the rise of the Modern evolutionary fauna. Science Advance, 3(2): e1602159. https://doi.org/10.1126/ sciadv.1602159

Brookfield, M.E., Williams, J.C. \& Stebbins, A.G., 2021. Paleoenvironments and geochemistry across a continuous Permian-Triassic boundary section at Bükk Mountains, Hungary. Geoscience Frontiers, 12(3): 101092. https://doi.org/10.1016/j.gsf.2020.09.021

Brosse, M., Bucher, H., Bagherpour, B., Baud, A., Frisk, Å.M., Guodun, K. \& Goudemand, N., 2015. Conodonts from the Early Triassic microbialite of Guangxi (South China): implications for the definition of the base of the Triassic System. Palaeontology, 58(3): 563:584. https://doi.org/10.1111/pala.12162

Brosse, M., Baud, A., Bhat, G.M., Bucher, H., Leu, M., Vennemann, T. \& Goudemand, N., 2017. Conodontbased Griesbachian biochronology of the Guryul Ravine section (basal Triassic, Kashmir, India). Geobios, 50(5-6):359-387. https://doi.org/10.1016/j.geobios.2017.10.001

Bucher, H., 1988. A new Middle Anisian (Middle Triassic) ammonoid zone from northwestern Nevada (USA). Eclogae geologicae Helvetiae, 81(3): 723762.

Bucher, H., 1989. Lower Anisian ammonoids from the Northern Humboldt Range (Northwestern Nevada, USA) and their bearing upon the Lower-Middle Triassic boundary. Eclogae Geologicae Helvetiae, 82(3): 945-1002.

Bucher, H., 1992. Ammonoids of the Hyatti Zone and the Anisian transgression in the Triassic Star Peak Group, 
northwestern Nevada, USA. Palaeontographica Abteilung A, 223: 137-166.

Bucher, H., 2002. Early Anisian (Middle Triassic) ammonoid biostratigraphy of northeastern British Columbia. Eclogae Geologicae Helvetiae, 95(3): 277287.

Budurov, K., 1976a. Structures, Evolution and Taxonomy of the Triassic Platform Conodonts. Geologica Balcanica, 6(1): 13-20.

Budurov, K., 1976b. Die Triassischen Conodonten des Ost-Balkans. Geologica Balcanica, 6(2): 95 - 104.

Budurov, K.J., Gupta, V.J., Sudar, M.N. \& Buryi, G.I., 1983. Triassic conodont biofacies and provinces. Bulletin of the Indian Geologists Association, 16(1): 8792.

Budurov, K.J., Gupta, V.J., Sudar, M.N. \& Buryi, G.I., 1985. Conodont zonation, biofacies and provinces in the Triassic. Journal Geological Society of India, 26(2): 84-94.

Budurov, K.J., Gupta, V.J., Kachroo, R.K. \& Sudar, M.N., 1987. Problems of the Lower Triassic Conodont Stratigraphy and the Permian-Triassic boundary. Journal Geological Society of India, 30: 80-81.

Budurov, K.J., Gupta, V.J., Kachroo, R.K. \& Sudar, M.N., 1988a. Problems of the Lower Triassic Conodont Stratigraphy and the Permian-Triassic Boundary. Memorie della Società Geologica Italiana, 34 (1986): 321-328.

Budurov, K.J., Sudar, M.N. \& Gupta, V.J., 1988 b. Kashmirella, a new Early Triassic conodont genus. Bulletin of the Indian Geologists Association, 21(2): 107-112.

Budurov, K.J., Sudar, M.N. \& Gupta, V.J., 1989. Early Triassic Parallel Conodont Zonation. Contribution to Himalayan Geology, 4: 158-166.

Budurov, K. \& Sudar, M., 1995. Lower Triassic stratigraphy. Geologica Balcanica, 25(3-4): 97-109.

Budurov, K. \& Trifonova, E., 1974. Die Conodontenund Foraminiferen-Zonen in der Trias des Ostbalkans. In: Zapfe, H. (ed.), Die Stratigraphie der alpinmediterranen Trias. Schriftenreihe der Erdwissenschaftlichen Kommissionen, Österreichische Akademie der Wissenschaften, 2: 57-62.

Budurov, K.J. \& Trifonova, E.T., 1984. Correlation of Triassic conodont and foraminiferal zonal standards in Bulgaria. Comptes rendus de l'Academie bulgare des Sciences, 37(5): 625-627.

Budurov, K. \& Trifonova, E., 1991. Stratigraphy of the Triassic in the Strandža-Sakar Region (South-East Bulgaria): conodont and foraminifer evidence. Review of the Bulgarian Geological Society, 52(3): 318.

Budurov, K. \& Trifonova, E., 1994. Progress in concepts about conodont and foraminifera zonal standards of the Triassic in Bulgaria. In: Guex, J. \& Baud, A. (eds.), Recent developments on Triassic stratigraphy (Proceedings of the Triassic Symposium, Lausanne,
20-23 Oct. 1991). Mémoires de Géologie (Lausanne), 22: 9-13.

Budurov, K. \& Trifonova, E., 1995. Conodont and foraminiferal successions from the Triassic of Bulgaria. Geologica Balcanica, 25(1): 13-19.

Burgess, S.D., Bowring, S. \& Shen, S.-Z., 2014. Highprecision timeline for Earth's most severe extinction. Proceedings of the National Academy of Sciences, 111(9): 3316-3321. www.pnas.org/cgi/doi/10.1073/ pnas.1317692111

Burij, I.V., Zharnikova, N.K. \& Buryi, G.I., 1976. On the question of the subdivision of the Lower Triassic deposits of South Primorye. Geologiya i Geofizika, 7: 150-155 [in Russian].

Buryi, G.I., 1979. Lower Triassic Conodonts of South Primorye. Academy of Sciences of the USSR, Moscow, 144 pp. [in Russian].

Buryi, G.I., 1989. Triassic conodonts and stratigraphy of Sikhote-Alin. Far Eastern Branch, Academy of Sciences of the USSR, Vladivostok, 136 pp. [in Russian].

Buryi, G.I., 1997. Triassic Conodont Biostratigraphy of the Sikhote-Alin. In: Baud, A., Popova, I., Dickins, J.M., Lucas, S. \& Zakharov, Y. (eds.), Late Paleozoic and Early Mesozoic Circum-Pacific Events: Biostratigraphy, Tectonic and Ore Deposits of Primoryie (Far East Russia). Mémoires de Géologie (Lausanne), 30: 45-60.

Buryi, G.I., Budurov, K.J., Sahni, A., Gupta, V.J., Kachroo, R.K., Chhabra, N.L., Ahluwalia, A.D. \& Azmi, R.J., 1980. On the validity of the name Neospathodus gondolelloides (Bender, 1968). Bulletin of the Indian Geologists Association, 13(2): 145-146.

Carey, S.P., 1984. Conodont biofacies of the Triassic of northwestern Nevada. In: Clark, D.L., (ed.), Conodont biofacies and provincialism. Geological Society of America Special Paper, 196: 295-305. https://org.doi/10.1130/SPE196-p295

Carter, E.S. \& Orchard, M.J., 2007. Radiolarian - conodont - ammonoid intercalibration around the NorianRhaetian Boundary and implications for transPanthalassan correlation. Albertiana, 36: 149-163.

Charlton, T.R., Barber, A.J., McGowan, A.J., Nicoll, R.S., Roniewicz, E., Cook, S.E., Barkham, S.T. \& Bird, P.R., 2009. The Triassic of Timor: Lithostratigraphy, chronostratigraphy and palaeogeography. Journal of Asian Earth Sciences, 36(4-5): 341-363. https://org.doi/10.1016/j.jseaes.2009.06.004

Chekhov, A.D., 1982. Tectonics of TalovskoPekulneyzone. In: Puscharovsky, V. M. (ed.), Outline of Tectonics of Koryak Highland. Nauka, Moscow, 70-105 [in Russian].

Chen, A.-F., Zhang, Y., Lyu, Z.-Y., Wu, H.-T. \& Zhang, K.-X., 2021. A new study of Olenekian-Anisian boundary conodont biostratigraphy of the Tulong section in Himalaya Terrane, southern Tibet. Palaeoworld, Article in Press. https://doi.org/10.1016/j. palwor.2021.09.008 
Chen, J., Song, H., He, W., Tong, J., Wang, F. \& Wu, S., 2019. Size variation of brachiopods from the Late Permian through the MiddleTriassic in South China: Evidence for the Lilliput Effect following the Permian-Triassic extinction. Palaeogeography, Palaeoclimatology, Palaeoecology, 519: 248-257. https://doi.org/10.1016/j.palaeo.2018.07.013

Chen, J., Shen, S.-Z., Zhang, Y.-C., Angiolini, L., Gorgij, M.N., Crippa, G., Wang, W., Zhang, H., Yuan, D.-X., Li, X.-H. \& Xua, Y.-G., 2020. Abrupt warming in the latest Permian detected using high-resolution in situ oxygen isotopes of conodont apatite from Abadeh, central Iran. Palaeogeography, Palaeoclimatology, Palaeoecology, 560: 109973. https://doi.org/10.1016/j.palaeo.2020.109973

Chen, Y.-L., Krystyn, L., Orchard, M.J., Lai, K.-L. \& Richoz, S., 2016. A review of the evolution, biostratigraphy, provincialism and diversity of Middle and early Late Triassic conodonts. Papers in Palaeontology, 2(2): 235-263. https://doi.org/10.1002/spp2.1038

Chen, Y., Jiang, H., Ogg, J.G., Zhang, Y., Gong, Y. \& Yan, C., 2020. Early-Middle Triassic boundary interval: Integrated chemo-bio-magneto-stratigraphy of potential GSSPs for the base of the Anisian Stage in South China. Earth and Planetary Science Letters, 530: 115863 . https://doi.org/10.1016/j.epsl.2019.115863

Chhabra, N.L., 1981. Some observations on boundary between Lower and Middle Triassic in Kashmir, India. Geoscience Journal, 2(1): 89-96.

Chhabra, N.L. \& Sahni, A., 1981. Late Lower Triassic and early Middle Triassic conodont faunas from Kashmir and in Kumaun sequences in Himalaya. Journal of the Palaeontological Society of India, 25: 135-147.

Chinese Triassic Working Group, 2007. Final report of the GSSP candidate for the I/O boundary at West Pingdingshan Section in Chaohu, Southeastern China. Albertiana, 36: 10-21.

Clapham, M.E., 2021. The End-Permian Mass Extinction. In: Alderton, D. \& Elias, S.A. (eds.), Encyclopedia of Geology, 2nd ed., Elsevier, 3: 645-652. https://doi.org/10.1016/B978-0-12-409548-9.12052-4

Clark, D.L., 1977. Late Paleozoic and Triassic Conodont Biostratigraphy: Correlations around the Expanding Atlantic Ocean. In: Swain, F.M. (ed.), Stratigraphic Micropaleontology of Atlantic Basin and Borderlands. Developments in Palaeontology and Stratigraphy, 6: 111-136.

Clark, D.L., Paull, K.R., Solien, M.A. \& Morgan, W.A., 1979. Triassic conodont biostratigraphy in the Great Basin. In: Sandberg, C.A. \& Clark, D.L. (eds.), Conodont biostratigraphy of the Great Basin and Rocky Mountains. Brigham Young University Geology Studies, 36: 179-185.

Collinson, J.W. \& Hasenmueller, W.A., 1978. Early Triassic paleogeography and biostratigraphy of the Cordileran Miogeosyncline. In: Howell, D.G. \&
McDougall, K.A. (eds.), Mesozoic paleogeography of the Western United States Symposium, Society of Economic Paleontologists and Mineralogists, Pacific Coast Paleogeography Symposium, 2: 175-187.

Dagys A.A., 1984. Early Triassic conodonts of northern Middle Siberia, Nauka, Moscow, 72 pp. [in Russian].

Dagys, A.S., 1988. Lower-Middle Triassic boundary in the Boreal and Tethyan regions and correlation of Anisian. Geology and Geophysics, 11: 3-9 [in Russian].

Dagys, A.S., 1994. Lower Triassic stage, substage and zonal scheme of north-eastern Asia. In: Guex, J. \& Baud, A. (eds.), Recent developments on Triassic stratigraphy (Proceedings of the Triassic Symposium, Lausanne, 20-23 Oct. 1991). Mémoires de Géologie (Lausanne), 22: 15-24.

Dagys, A.S. \& Ermakova, S.P., 1986. The genus Keyserlingites and its stratigraphic significance. Geology and Geophysics, 2: 2-26 [in Russian].

Dagys, A. \& Ermakova, S., 1996. Induan (Triassic) ammonoids from north-eastern Asia. Revue de Paléobiologie, 15: 401-447.

Dagys, A.S. \& Tozer, E.T., 1989. Correlation of Triassic in northern Canada and Siberia. U.S.S.R. Academy of Sciences, Siberian Branch, Geology and Geophysics, 6: 3-9.

Dagys, A.S. \& Weitschat, W., 1993. Correlation of the Boreal Triassic. Mitteilungen aus dem Geologisch Paläontologischen Institut der Universität Hamburg, 75: 249-256.

Dagys, A.S. \& Sobolev, E.S., 1995. Parastratotypes of the Olenekian Stage (lower Triassic). Albertiana, 16: 816.

Dagys, A.S., Dagys, A.A. \& Klets, T.V., 1983. Questions of the biostratigraphy and paleobiogeography of Trias of the exotic blocks of North-Western Pacific. In: Soloviev, V.A. (ed.), Stage and zonal scales of the Boreal Mesozoic of the USSR, Nauka, Moscow, pp. 52-60 [in Russian].

Diener, C., 1915. Cephalopoda triadica. Fossilium Catalogus. I: Animalia, Pars 8, W. Junk Berlin, 369 pp.

Du, Y., Song, H., Tong, J., Algeo, T.J., Li, Z., Song, H. \& Huang, J., 2021. Changes in productivity associated with algal-microbial shifts during the Early Triassic recovery of marine ecosystems. Geological Society of America Bulletin, 133(1-2): 362-378. https://doi .org/10.1130/B35510.1

Fantini Sestini, N., 1981. Lower Anisian (Aegean) Ammonites from Chios Island (Greece). Rivista Italiana di Paleontologia e Stratigrafia, 87(1): 41-66.

Feng, M.-S., Meng, W.-B., Zhang, C.-G., Qing, H.-R., Chi, G.-X., Wang, J., Peng, Y.-W., Wen, H.-G. \& Huang, H., (2021). Geochronology and geochemistry of the 'green-bean rock' (GBR, a potassium-rich felsic tuff) in the western margin of the Yangtze platform, SW China: Significance for the OlenekianAnisian boundary and the Paleo-Tethys. Lithos, 382- 
383:105922. https://doi.org/10.1016/j.lithos.2020. 105922

Finney, S.C., 2013. The Reality of GSSPs. Ciências da Terra, 18: 9-12.

Foster, W.J., Heinde, K., Richoz, S., Gliwa, J., Lehrmann, D.J., Baud, A., Kolar-Jurkovšek, T., Aljinović, D., Jurkovšek, B., Korn, D., Martindale, R.C. \& Peckmann, J., 2019. Suppressed competitive exclusion enabled the proliferation of Permian/Triassic boundary microbialites. The Depositional Record, 6: 62-74. https://doi.org/10.1002/dep2.97

Fuchs, G. \& Mostler, H., 1969. Mikrofaunen aus der Tibet-Zone, Himalaya. Verhandlungen der Geologischen Bundesanstalt (1969): 133-143.

Gaetani, M., 1994. Working Group on the Anisian, Ladinian and Carnian stage boundaries - annual report. Albertiana, 14: 51-53.

Gaetani, M., 2000. Report on the STS activity. Albertiana, 24: 4-8.

Gaetani, M., Jacobshagen, V., Nicora, A., Kauffmann, G., Tselepidis, V., Fantini Sestini, N., Mertmann, D. \& Skourtsis-Coroneou, V., 1992. The Early-Middle Triassic boundary at Chios (Greece). Rivista Italiana di Paleontologia e Stratigrafia, 98(2): 181-204.

Galbrun, B., Boulila, S., Krystyn, L., Richoz, S., Gardin, S., Bartolini, A. \& Maslo, M., 2020. "Short" or "long" Rhaetian ? Astronomical calibration of Austrian key sections. Global Planetary Change, 192: 103253. https://doi.org/10.1016/j.gloplacha.2020.103253

Galfetti, T., Bucher, H., Ovtcharova, M., Schaltegger, U., Brayard, A., Brühwiller, T., Goudemand, N., Weissert, H., Hochuli, P.A., Cordey, F. \& Guodun, K., 2007. Timing of the Early Triassic carbon cycle perturbation inferred from new U-Pb ages and ammonoid biochronozones. Earth and Planetary Science Letters, 258(3-4): 593-604. https://doi.org/10.1016/j.epsl. 2007.04.023

Galfetti, T., Bucher, H., Martini, R., Hochuli, P.A., Weissert, H., Crasquin-Soleau, S., Brayard, A., Goudemand, N., Bruchwiler, T. \& Kuang, G.D., 2018. Evolution of Early Triassic outer platform paleoenvironments in the Nanpanjiang Basin (South China) and their significance for the biotic recovery. Sedimentary Geology, 204(1-2): 36-60. https://doi. org?10.1016/j. sedgeo.2007.12.008

Garzanti, E., Jadoul, F., Nicora, A. \& Berra, F., 1995. Triassic of Spiti (Tethys Himalaya, N India). Rivista Italiana di Paleontologia e Stratigrafia, 101(3): 267300. https://doi.org/10.13130/2039-4942/8588

Germani, D., 1997. New data on ammonoids and biostratigraphy of the classical Spathian Kçira sections (Lower Triassic, Albania). Rivista Italiana di Paleontologia e Stratigrafia, 103(3): 267-292.

Giordano, N., Rigo, M., Ciarapica, G. \& Bertinelli, A., 2010. New biostratigraphical constraints for the Norian/Rhaetian boundary: Data from Lagonegro basin, Southern Apennines, Italy. Lethaia, 43: 573-586. https://doi.org/10.1111/j.1502-3931.2010.00219.x
Goel, R.K., 1977. Triassic conodonts from Spiti (Himachal Pradesh), India. Journal of Paleontology, 51(6): 1085-1101.

Golding, M.L., 2014. Biostratigraphy and sedimentology of Triassic hydrocarbon-bearing rocks in northeastern British Columbia. PhD thesis, The University of British Columbia, 388 pp.

Golding, M.L., 2021a. Early Anisian (Middle Triassic) conodonts from Romania and China, with comments on their role in the recognition and correlation of the base of the Anisian. Journal of Earth Science, 32(3): 573-591. https://doi.org/10.1007/s12583-020-1392-9

Golding, M.L., 2021b. Abundant conodont faunas from the Olenekian (Early Triassic) of subsurface British Columbia, Canada and diversification of the Neogondolellinae around the Smithian-Spathian boundary. Global and Planetary Change, 205: 103613. https://doi.org/10.1016/j.gloplacha.2021.103613

Golding, M.L., Orchard, M.J. \& Zonneveld, J.-P., 2014. A summary of new conodont biostratigraphy and correlation of the Anisian (Middle Triassic) strata in British Columbia, Canada. Albertiana, 42: 33-40.

Golding, M.L., Orchard, M.J., Zonneveld, J.-P. \& Wilson, N.S.F., 2015. Determining the age and depositional model of the Doig Phosphate Zone in northeastern British Columbia using conodont biostratigraphy. Bulletin of Canadian Petroleum Geology, 63: 143-170.

Golebiowski, R., 1990. The Alpine Kössen Formation. A key for European topmost Triassic correlations. A Sequence- and Ecostratigraphic Contribution to the Norian-Rhaetian Discussion. Albertiana, 8: 25-35.

Gorter, J.D., Nicoll, R.S. \& Caudullo, A., 2008. Revised stratigraphy of the Triassic (Induan to Carnian) in the northern Perth, Carnavaron and offshore Canning basins. AESC Poster.

Gorter, J.D., Orchard, M.J., Nicoll, R.S. \& Ferdinando, D., 2019. Significance of Early Triassic conodont zones from Western Australia, ASEG Extended Abstracts, 1: 1-4. https://doi.org/10.1080/22020586.2019.12073117

Goudemand, N., Orchard, M.J., Bucher, H. \& Jenks, J., 2012. The elusive origin of Chiosella timorensis (Conodont Triassic). Geobios, 45: 199-207. https://doi.org/10.1016/j.geobios.2011.06.001

Grădinaru, E., 2000. Introduction to the Triassic geology of North Dobrogea Orogene - An overview of the Triassic System in the Tulcea Unit and the ammonoid biostratigraphy. In: Grădinaru, E. (ed.), Workshop on the Lower-Middle Triassic (Olenekian-Anisian) boundary, 7-10 June, Tulcea, Romania. Field Trip Section, pp. 5-37.

Grădinaru, E., Orchard, M., Nicora, A., Mirăuţă, E. \& Atudorei, V., 2002. Conodont succession across the Olenekian-Anisian boundary at Deşli Caira, Romania. STS/IGCP 467 Field Meeting, Veszprém, Hungary, 58 September 2002, pp. 11-13. 
Grădinaru, E., Kozur, H.W., Nicora, A. \& Orchard, M. J., 2006. The Chiosella timorensis and correlation of the ammonoids and conodonts around the base of the Anisian in the GSSP candidate at Deşli Caira (North Dobrogea, Romania). Albertiana, 34: 34-38.

Grădinaru, E., Orchard, M.J., Nicora, A., Gallet, Y., Besse, J., Krystyn, L., Sobolev, E.S., Atudorei, N.-V. \& Ivanova, D., 2007. The Global Boundary Stratotype Section and Point (GSSP) for the base of the Anisian Stage: Deşli Caira Hill, North Dobrogea, Romania. Albertiana, 36: 54-71.

Grădinaru, E. \& Sobolev, E.S., 2006. Ammonoid and Nautiloid Biostratigraphy around the OlenekianAnisian Boundary in the Tethyan Triassic of North Dobrogea (Romania): Correlation with the Boreal Triassic. In: Boreal Triassic 2006, Abstracts and Proceeding of the Geological Society of Norway, 3: 5658.

Grădinaru, E. \& Sobolev, E.S., 2010. First record of Rhabdoceras suessi (Ammonoidea, Late Triassic) from the Transylvanian Triassic Series of the Eastern Carpathians (Romania) and a review of its biochronology, paleobiogeography and paleoecology. Central European Geology, 53(2-3): 261-309. https://doi.org/ 10.1556/ceugeol.53.2010.2-3.8

Grădinaru, E. \& Gaetani, M., 2019. Upper Spathian to Bithynian (Lower to Middle Triassic) brachiopods from North Dobrogea (Romania). Rivista Italiana di Paleontologia e Stratigrafia, 125(1): 91-123. https://doi.org/10.13130/2039-4942/11182

Gradstein, F.M., Ogg, J.G. \& Smith, A.G., 2004. A Geologic Time Scale 2004. Cambridge University Press, Cambridge, 589 pp.

Gradstein, F.M., Ogg, J.G., Schmitz, M.D. \& Ogg, G.M., 2012. The Geologic Time Scale 2012. Elsevier, 1144 pp.

Gradstein, F.M., Ogg, J.G., Schmitz, M.D. \& Ogg, G.M., 2020. Geologic Time Scale 2020. Elsevier, 1357 pp.

Guex, J., 1978. Le Trias inférieur des Salt Ranges (Pakistan): problèmes biochronologuiques. Eclogae geologicae Helvetiae, 71(1): 105-141.

Guex, J., Hungerbühler, A., Jenks, J. F., O’Dogherty, L., Atudorei, V., Taylor, D.G., Bucher, H. \& Bartolini, A., 2010. Spathian (Lower Triassic) ammonoids from western USA (Idaho, California, Utah and Nevada). Mémoires de Géologie (Lausanne), 49: 82 pp.

Gupta, V.J., 1983. Triassic Conodonts from Ladakh and Spiti. In: Zapfe, H. (ed.), Neue Beiträge zur Biostratigraphie der Tethys-Trias. Schriftenreihe der Erdwissenschaftlichen Kommissionen, Österreichische Akademie der Wissenschaften, 5: 7-16.

Gupta, V.J. \& Budurov K.J., 1981. Triassic conodonts from Spiti (Himalaya, India) and their correlations: preliminary data. Geologica Balcanica, 11(1): 21-26.

Ha, T.T.N., Takayanagi, H., Ueno, K., Asahara, Y., Yamamoto, K. \& Iryu, Y., (2019). Litho-, bio-, and chemostratigraphy of the Middle Triassic carbonate succession in the North-Central Coast Region of
Vietnam. Progress in Earth and Planetary Science, 6: 47. https://doi.org/10.1186/s40645-019-0293-y

Ha, T.T.N., Maekawa, T., Takayanagi, H. \& Iryu, Y., 2021. Spathian to Aegean (upper Lower Triassic to lower Middle Triassic) carbon isotope stratigraphy constrained by the conodont biostratigraphy of carbonates on top of a mid-oceanic seamount formed in the Panthalassic Ocean. Island Arc, 30(1): e12391. https://doi.org/10.1111/iar.12391

Hammer, Ø., Jones, M.T., Schneebeli-Hermann, E., Hansen, B.B. \& Bucher, H., 2019. Are Early Triassic extinction events associated with mercury anomalies ? A reassessment of the Smithian/Spathian boundary extinction. Earth-Science Reviews, 195: 179-190. https://doi.org/10.1016/j.earscirev.2019.04.016

Haq, B.U., 2018. Triassic Eustatic Variations Reexamined. GSA Today, 28(12): 4-9. https://doi.org /10.1130/GSATG381A.1; with supplement online at www.geosociety.org/ datarepository/2018/

Hirsch, F. \& Ishida, K., (2002). The Izanami Plateau: Preaccretionary origin of Japan's low latitude Triassic pelagic carbonates. Eclogae Geologicae Helvetiae, 95: 43-56.

Hirsch, F., Ishida, K., Kozai, T. \& Meespook, A., 2006. The welding of Shan-Thai. Geosciences Journal, 10(3): 195-204. G704-000565.2006.10.3.011

Horacek, M., Richoz, S., Brandner, R., Krystyn, L. \& Spötl, C., 2007. Evidence for recurrent changes in Lower Triassic oceanic circulation of the Tethys: the $\delta^{13} \mathrm{C}$ record from marine sections in Iran. Palaeogeography, Palaeoclimatology, Palaeoecology, 252: 355369.

https://doi.org/10.1016/j.palaeo.2006.11.052

Horacek, M., Koike, T. \& Richoz, S., 2009. Lower Triassic $\delta^{13} \mathrm{C}$ isotope curve from shallow-marine carbonates in Japan, Panthalassa realm: Confirmation of the Tethys $\delta^{13} \mathrm{C}$ curve. Journal of Asian Earth Sciences, 36: 481-490. https://doi.org/10.1016/ j.jseaes.2008.05.005

Hounslow, M.W. \& McIntosh, G., 2003. Magnetostratigraphy of the Sherwood Sandstone Group (Lower and Middle Triassic), south Devon, U.K.: detailed correlation of the marine and non-marine Anisian, Palaeogeography, Palaeoclimatology, Palaeoclimatology, 193: 325-348. https://doi.org/10.1016/S0031-0182 (03)00235-9

Hounslow, M.W. \& Muttoni, G., 2010. The geomagnetic polarity timescale for the Triassic: linkage to stage boundary definitions. In: Lucas, S.D. (ed.), The Triassic Timescale. Geological Society, London, Special Publication, 334: 61-102. https://doi.org/ 10.1144/SP334.4

Hounslow, M.W., Szurlies, M., Muttoni, M. \& Nawrocki, J., 2007. The magnetostratigraphy of the OlenekianAnisian boundary and a proposal to define the base of the Anisian using a magnetozone datum. Albertiana, 36: $72-77$. 
Hounslow, M.W., Hu, M., Mørk, A., Weitschat, W., Vigran, J.O., Karloukovski, V. \& Orchard, M.J., 2008. Intercalibration of Boreal and Tethyan time scales: the magnetostratigraphy of the Middle Triassic and the latest Early Triassic from Spitsbergen, Arctic Norway. Polar Research, 27(3): 469-490. https://doi.org/10.1111/j.1751-8369.2008.00074.x

Huang, C., 2018. Astronomical Time Scale for the Mesozoic. In: Montenari, M. (ed.), Cyclostratigraphy and Astrochronology. Stratigraphy and Timescales, 3: 81150. https://doi.org/10.1016/bs.sats.2018.08.005

Huckriede, R., 1958. Die Conodonten der Mediterranen Trias und ihr stratigraphischer Wert. Paläontologische Zeitschrift, 32: 141-175.

Igo, H. \& Koike, T., 1983. Conodont biostratigraphy of cherts in the Japanese Islands. Developments in Sedimentology, 36: 65-77. International Commission on Stratigraphy, 2004. Consolidated annual report, compiled by Gradstein, F.M., and Ogg, J.G. http://www.stratigraphy.org/gssp.htm (December2005).

Ishida, K., 1979. Studies of the South Zones of the Chichibu Belt in Shikoku, Part II. Stratigraphy and structure around Nagayasu-guchi Dam, Yokushima Prefecture. Journal Science, University of Tokushima, 12: 61-92 [in Japanese, with English Abstract].

Ishida, K. \& Hirsch, F., 2011. The Triassic conodonts of the NW Malayan Kodiang Limestone revisited. Taxonomy and paleogeographic significance. Gondwana Research, 19(1):22-36. https://doi.org/10.1016/j.gr. 2010.05.008

Isozaki, Y., Maruyama, S. \& Furuoka, F., 1990. Accreted oceanic materials in Japan. In: Kono, M. \& Burchfiel, B.C. (eds.), Tectonics of Eastern Asia and Western Pacific Continental Margin. Tectonophysics, 181: 179-205. https://doi.org/10.1016/0040-1951(90) 90016-2

Jacobshagen, V. \& Tietze, K.W., 1974. Biostratigraphische Probleme im Skyth/Anis-Grenzbereich auf der Insel-Chios (Agäis). Schriftenreihe der Erdwissenschaftlichen Kommissionen, Österreichische Akademie der Wissenschaften, 2: 115-123.

Jacobshagen, V., Gaetani, M., Nicora, A., Tselepedis, V., Kauffmann, G., Mertmann, D., Skourtsis-Coroneou, V. \& Fantini Sestini, N., 1993. The Early/Middle Triassic boundary on Chios Island: preliminary results of a reinvestigation. Bulletin of the Geological Society of Greece, 28: 25-38.

Jenks, J.F., Monnet, C., Balini, M., Brayard, A. \& Meier, M., 2015. Biostratigraphy of Triassic Ammonoids. In: Klug, C., Korn, D., De Baets, K., Kruta, I. \& Mapes, R.H. (eds.), Ammonoid Paleobiology: From macroevolution to paleogeography. Topics in Geobiology, 44: 329-388. Springer. https://doi.org/10.1007/97894-017-9633-0_13

Jenks, J.F., Maekawa, T., Ware, D., Shigeta, Y., Brayard, A. \& Bylund, K.G., 2021. Late Griesbachian (Early Triassic) ammonoids and nautiloids from the Din- woody Formation at Crittenden Springs, Elko County, Nevada. New Mexico Museum of Natural History and Science Bulletin, 86: 1-23.

Ji, W., Tong, J., Zhao, L., Zhou, S. \& Chen, J., 2011. Lower-Middle Triassic conodont biostratigraphy of the Qingyan section, Guizhou Province, Southwest China. Palaeogeography, Palaeoclimatology, Palaeoecology, 308(1-2): 213-223. https://doi.org/10.1016/j. palaeo.2010.08.020

Jiang, H.S., Lai, X.L., Luo, G.M., Aldridge, R., Zhang, K.X. \& Wignall, P., 2007. Restudy of conodont zonation and evolution across the $\mathrm{P} / \mathrm{T}$ boundary at Meishan section, Changxing, Zhejiang, China. Global and Planetary Change, 55: 39-55. https://doi.org/ 10.1016/j.gloplacha.2006.06.007

Joachimski, M.M., Lai, X., Shen, S.Z., Jiang, H., Luo, G., Chen, B., Chen, J. \& Sun, Y., 2012. Climate warming in the latest Permian and the Permian-Triassic mass extinction. Geology, 40(3):195-198. https://doi. org/10.1130/G32707.1

Joachimski, M.M, Alekseev, A.S, Grigoryan, A. \& Gatovsky, Yu. A., 2019. Siberian trap volcanism, global warming and the Permian-Triassic mass extinction: new insights from Armenian Permian-Triassic sections. GSA Bulletin, 132(1-2): 427-443. https://doi.org/10.1130/B35108.1

Kelley, B.M., Lehrmann, D.J., Yu, M., Jost, A.B., Meyer, K.M., Lau, K.V., Altiner, D., Li, X., Minzoni, M., Schaal, E.K. \& Payne, J.L., 2020. Controls on carbonate platform architecture and reef recovery across the Palaeozoic to Mesozoic transition: A highresolution analysis of the Great Bank of Guizhou. Sedimentology, 67: 3119-3151. https://doi.org/ 10.1111/sed.12741

Kemper, E., Maronde, H.-D. \& Stoppel, D., 1976. Triassic and Jurassic Limestone in the Region Northwest and West of Si Sawar (Kanchanaburi Province, Western Thailand). Geologisches Jahrbuch Hannover. B 21: 93 - 127.

Kiliç, A.M., 2021. Anisian (Middle Triassic) Conodonts of the Kocaeli Triassic, Western Turkey. Journal of Earth Science, 32(3): 616-632. https://doi.org/10. 1007/s12583-020-1384-9

Kiliç, A.M., Plasencia, P., Ishida, K., Guex, J. \& Hirsch, F., 2015. Conodonts versus Triassic Climatic and Eustatic Changes. Procedia Earth and Planetary Science, 15: 321-324. https://doi.org/10.1016/j.proeps.2015.08.080

Kiliç, A.M., Plasencia, P., Ishida, K., Guex, J. \& Hirsch, F., 2016. Proteromorphosis of Neospathodus (Conodonta) during the Permian-Triassic crisis and recovery. Revue de Micropaléontologie, 59(1): 33-39. http://dx.doi.org/10.1016/j.revmic.2016.01.003

Klets, T.V., 1995. Triassic Biostratigraphy and Conodonts from the Central Sikhote-Alin. NGU, Novosibirsk, 111 pp. [in Russian].

Klets, T.V., 1998. New Conodont Species from Lower Triassic of the Kolyma River Basin. News of Paleon- 
tology and Stratigraphy, Supplement to Geologiya i Geofizika, 39 (1): 113-121 [in Russian].

Klets, T.V., 2005. Palaeobiogeographic zoning of Triassic Seas on Northeastern Asia based on Conodontophoridae. Albertiana, 32: 40-56.

Klets, T.V., 2006. Diversity and Stages in Evolution of Conodontophorids and Bivalve Mollusks in Triassic Seas of Siberia and the Far East. Stratigraphy and Geological Correlation, 14(2): 174-184. https://doi.org/ 10.1134/S0869593806020055

Klets, T.V., 2008. Paleogeographic Regionalization of Triassic Seas Based on Conodontophorids. Stratigraphy and Geological Correlation, 16(5): 467-489. https://doi.org/10.1134/S086959380805002X

Klets, T.V. \& Kopylova, A.V., 2008. The first finding of the genus Chiosella Kozur 1989 (Conodonts of upper Olenekian) in the northeast Russia. News of Paleontology and Stratigraphy, Supplement to Geologiya i Geofizika, 49(10-11): 222-227 [in Russian].

Koike, T., 1973. Triassic Conodonts from Kedah and Pahang, Malaysia. Geology and Palaeontology of Southeast Asia, 12: 91-113.

Koike, T., 1979a. Biostratigraphy of Triassic conodonts. In: Igo, H. \& Koike, T. (eds.), Biostratigraphy of Permian and Triassic Conodonts and Holothurian Sclerites in Japan. Memoir Volume Prof. Mosaburo Kanuma, Tokyo, Japan, pp. 21-77 [in Japanese].

Koike, T., 1979b. Conodont Biostratigraphy of the Taho Limestone (Triassic) in the Shirokawa-cho, Ehime Prefecture. In: Igo, H. \& Koike, T. (eds.), Biostratigraphy of Permian and Triassic Conodonts and Holothurian Sclerites in Japan. Memoir Volume Prof. Mosaburo Kanuma, Tokyo, Japan, pp. 115-126 [in Japanese].

Koike, T., 1981. Biostratigraphy of Triassic Conodonts in Japan. Science Reports of the Yokohama National University, Biology and Geology, 28: 25-42.

Koike, T., 1999. Apparatus of a Triassic conodont species Cratognathodus multihamatus (Huckriede). Paleontological Research, 3: 234-248.

Koike, T., Igo, H., Takizawa, S. \& Kinoshita, T., 1971. Contribution to the geological history of the Japanese Islands by the conodont biostratigraphy, Part II, Journal of the Geological Society of Japan, 77(3): 165168.

Konstantinov, A.G. \& Klets, T.V., 2009. Stage Boundaries of the Triassic in Northeast Asia. Stratigraphy and Geological Correlation, 17(2): 173-191. https://doi. org/10.1134/S0869593809020063

Konstantinov, A.G., Sobolev, E.S., Kurushin, N.I., Klets, T.V. \& Yadrenkin, A.V., 1997. Zonal Zonation of the Triassic deposits in the Omulevka Uplift (Kolyma basin). Russian Geology and Geophysics, 38(10): 16911706.

Kovács, S. \& Kozur, H., 1980. Stratigraphische Reichweite der wichtigsten Conodonten (ohne Zahnreihenconodonten) der Mittel- und Obertrias.
Geologisch-Paläontologische Mitteilungen Innsbruck, 10(2): 47-78.

Kozur, H., 1972. Vorläufige Mitteilung zur Parallelisierung der germanischen und tethyalen Trias sowie einige Bemerkungen zur Stufen- und Unterstufengliederung der Trias. Mitteilungen der Gesellschaft der Geologie- und Bergbaustudenten in Österreich, 21(2): 361-412.

Kozur, H., 1973a. Beiträge zur Stratigraphie und Paläontologie der Trias.Geologisch-Paläontologische Mitteilungen Innsbruck, 3(1): 1-30.

Kozur, H., 1973b. Beiträge zur Stratigraphie von Perm und Trias. Geologisch-Paläontologische Mitteilungen Innsbruck, 3(3): 1-31.

Kozur, H., 1973c. Faunenprovinzen in der Trias und ihre Bedeutung für die Klärung der Paläogeographie. Geologisch-Paläontologische Mitteilungen Innsbruck, 3(8): 1-41.

Kozur, H., 1974. Probleme der Triasgliederung und Parallelisierung der germanischen und tethyalen Trias: Teil I: Abgrenzung und Gliederung der Trias. Freiberger Forschungshefte, C298: 139-197.

Kozur, H., 1975. Probleme der Triasgliederung und Parallelisierung der germanischen und tethyalen Trias:

Teil II: Anschluß der germanischer Trias an die international Triasgliederung. Freiberger

Forschungshefte, C304: 51-77.

Kozur, H., 1980a. The main events in the Upper Permian and Triassic conodont evolution and its bearing to the Upper Permian and Triassic stratigraphy. Rivista Italiana di Paleontologia e Stratigrafia, 85(3-4): 741-766.

Kozur, H., 1980b. Revision der Conodontenzonierung der Mittel- und Obertrias des tethyalen Faunenreichs. Geologisch-Paläontologische Mitteilungen Innsbruck, 10(3-4): 79-172.

Kozur, H., 1989a. Significance of events in conodont evolution for the Permian and Triassic stratigraphy. Courier Forschungs-Institut Senckenberg, 117, 385408.

Kozur, H., 1989b. The taxonomy of the Gondolellid Conodonts in the Permian and Triassic. Courier Forschungs-Institut Senckenberg, 117: 409-469.

Kozur, H.W., 1999. The correlation of the Germanic Buntsandstein and Muschelkalk with the Tethyan scale. Zentralblatt für Geologie und Paläontologie, I(7-8): 701-725.

Kozur, H.W., 2003a. Integrated ammonoid, conodont and radiolarian zonation of the Triassic and some remarks to Stage/Substage subdivision and the numeric age of the Triassic stages. Albertiana, 28: 57-74.

Kozur, H.W., 2003b. Integrated ammonoid, conodont and radiolarian zonation of the Triassic. Hallesches Jahrbuch für Geowissenschaften, B 25: 49-79.

Kozur, H.W. \& Bachmann, G.H., 2005. Correlation of the Germanic Triassic with the international scale. Albertiana, 32: 21-35.

Kozur, H. \& Mostler, H., 1972. Die Bedeutung der Conodonten für stratigraphische und paläogeographische 
Untersuchungen in der Trias. Mitteilungen der Gesellschaft der Geologie- und Bergbaustudenten in Österreich, 21(2): 777-810.

Kozur, H.W., Krainer, K. \& Mostler, H., 1995. A conodont rich pelagic Olenekian-Anisian boundary section in the Sosio Valley area, western Sicily (Italy). Albertiana, 15: 24-26.

Krystyn, L., 1980. Stratigraphy of the Hallstatt region. In: Krystyn, L., Plöchinger, B. \& Lobitzer, H. (eds.), Field Trip B, Triassic conodont localities of the Salzkammergut region. Abhandlungen der Geologischen Bundesanstalt, 35: 69-98.

Krystyn, L., 1988. Zur Rhät-Stratigraphie in den Zlambach-Schichten (vorläufiger Bericht). Sitzungsberichte der Österreichischen Akademie der Wissenschaften Mathematisch-Naturwissenschaftliche Klasse, 196(3): 21-36.

Krystyn, L., 1990. A Rhaetian stage-chronostratigraphy, subdivisions and their intercontinental correlation. Albertiana, 8: 15-24.

Krystyn, L., 1991. Die Fossillagerstätten der alpine Trias. In: Vasicek, V., Krystyn, L. \& Golebiowski, R. (eds.), Exkursion im Jungpaläozoikum und Mesozoikum Österreichs. Österreichischen Paläontologischen Gesellschaft, pp. 23-78.

Krystyn, L., 2008a. An ammonoid-calibrated Tethyan conodont time scale of the late Upper Triassic. Berichte der Geologischen Bundesanstalt, 76: 9-11.

Krystyn, L., 2008b. The Hallstatt pelagics - Norian and Rhaetian Fossillagerstaetten of Hallstatt. Berichte der Geologischen Bundesanstalt, 76: 81-98.

Krystyn, L., 2010. Decision report on the defining event for the base of the Rhaetian stage. Albertiana, 38: 1112.

Krystyn, L., Balini, M. \& Nicora, A., 2004. Lower and Middle Triassic stage and substage boundaries in Spiti. Albertiana, 30: 40-53.

Krystyn, L. \& Kuerschner, W., 2005. Biotic events around the Norian-Rhaetian boundary from a Tethyan perspective. Albertiana, 32: 17-20.

Krystyn, L., Bhargava, O.N. \& Richoz, S., 2007a. A candidate GSSP for the base of the Olenekian Stage: Mud at Pin Valley; district Lahul \& Spiti, Himachal Pradesh (Western Himalaya), India. Albertiana, 35: 5-20.

Krystyn, L., Richoz, S. \& Bhargava, O.N., 2007b. The Induan-Olenekian Boundary (IOB) - an update of the candidate GSSP section M04. Albertiana, 36: 33-45.

Krystyn, L., Bouquerel, H., Kuerschner, W., Richoz, S. \& Gallet, Y., 2007c. Proposal for a candidate GSSP for the base of the Rhaetian Stage. The Global Triassic. New Mexico Museum of Natural History and Science Bulletin, 41: 189-199.

Krystyn, L., Richoz, S., Gallet, Y., Bouquerel, H., Kürschner, W.M. \& Spötl, C., 2007d. Updated bioand magnetostratigraphy from Steinbergkogel (Austria), candidate GSSP for the base of the Rhaetian stage. Albertiana, 36: 164-172.
Krystyn, L., Richoz, S., Maslo, M., Kuerschner, W., Gardin, S. \& Gallet, Y., 2015. Proposal for a candidate GSSP for the base of the Rhaetian stage at Steinbergkogel (Salzkammergut, Austria). Berichte des Institutes für Erdwissenschaften Karl-FranzensUniversität Graz, 21: 213.

Kummel, B., 1969. Ammonoids of the Late Scythian (Lower Triassic). Bulletin of the Museum of Comparative Zoology, 137(3): 311-701.

Kummel, B., 1973a. Aspects of the Lower Triassic (Scythian) Stage. In: Logan, A. \& Hills, L.V. (eds.), The Permian and Triassic Systems and their Mutual Boundary, Canadian Society of Petroleum Geologists, Calgary, 557-571.

Kummel, B., 1973b. Lower Triassic (Scythian) Molluscs. In: Hallam, A. (ed.), Atlas of Paleobiogeography, Elsevier, Amsterdam, 225-233.

Kutassy, A., 1932. Cephalopoda Triadica II. Fossilium Catalogus I Animalia, Pars 56, Berlin, 371-832.

Kutygin, R,V., Budnikov, I.V., Biakov, A.S., Davydov, V.I., Kilyasov, A.N. \& Silantiev, V.V., 2019. First Findings of Otoceras (Ceratitida) in the Kobyuma Zone of the Southern Verkhoyansk Region, Northeastern Russia. Proceedings of Kazan University, Natural Sciences Series, 161(4): 550-570 [in Russian, with English abstract].

Lehrmann, D., Enos, P., Montgomery, P., Payne, J., Orchard, M., Bowring, S., Ramezani, J., Martin, M., Jiayong, W., Hongmei, W., Youyi, Y., Jiafei, X. \& Rongxi, L., 2002. Integrated biostratigraphy, magnetostratigraphy, and geochronology of the OlenekianAnisian boundary in marine strata of Guandao section, Nanpanjiang Basin, south China: implications for timing the biotic recovery from the end-Permian extinction. STS/IGCP 467 Field Meeting, Veszprém, Hungary, 5-8 September 2002, pp. 7-9.

Lehrmann, D.J., Ramezani, J., Bowring, S.A., Martin, M.W., Montgomery, P., Enos, P., Payne, J., Orchard, M., Wang, H. \& Wei, J., 2006. Timing of recovery from the end-Permian extinction: Geochronologic and biostratigraphic constraints from south China. Geology, 34(12): 1053-1056. https://doi.org/10.1130/G22827A.1

Lehrmann, D.J., Payne, J., Enos, P., Montgomery, P., Wei, J., Yu, Y., Hiao, J. \& Orchard, M.J., 2015a. Field excursion 2. Permian-Triassic boundary and a Lower-Middle Triassic boundary sequence on the Great Bank of Guizhou, Nanpanjiang Basin, southern Guizhou Province. Albertiana, 33: 169-186.

Lehrmann, D.J., Stepchinski, L., Altiner, D., Orchard, M., Montgomery, P., Enos, P., Ellwood, B.B., Bowring, S.A., Ramezani, J., Wang, H., Wei, J., Yu, M., Griffiths, J.D., Minzoni, M., Schaal, E.K., Li, X., Meyer, K.M. \& Payne, J.L., 2015b. An integrated biostratigraphy (conodonts and foraminifers) and chronostratigraphy (paleomagnetic reversals, magnetic susceptibility, elemental chemistry, carbon isotopes and geochronology) for the Permian-Upper Triassic strata of 
Guandao section, Nanpanjiang Basin, south China. Journal of Asian Earth Sciences, 108:117-135. https://doi.org/10.1016/j.jseaes.2015.04.030

Li, F., Yan, J., Algeo, T. \& Wu, X., 2013. Paleoceanographic conditions following the end-Permian mass extinction recorded by giant ooids (Moyang, South China). Global and Planetary Change, 105: 102-120. https://doi.org/10.1016/j.gloplacha.2011.09.009

Li, F., Yan, J., Chen, Z.-Q., Ogg, J.G., Tian, L., Korngreen, D., Liu, K., Ma, Z. \& Woods, A.D., 2015. Global oolite deposits across the Permian-Triassic boundary: A synthesis and implications for palaeoceanography immediately after the end-Permian biocrisis. Earth-Science Reviews, 149: 163-180. http://dx.doi.org/10.1016/j.earscirev.2014.12.006

Li, F., Yan, J., Burne, R.V., Chen, Z.-Q., Algeo, T.J., Zhang, W., Tian, L., Gan, Y., Liu, K. \& Xie, S., 2017. Paleo-seawater REE compositions and microbial signatures preserved in laminae of Lower Triassic ooids. Palaeogeography, Palaeoclimatology, Palaeoecology, 486: 96-107. http://dx.doi.org/10.1016/j.palaeo. 2017.04.005

Li, F., Gong, Q., Burne, R.V., Tang, H., Su, C., Zeng, K., Zhang, Y. \& Tan, X., 2019. Ooid factories operating under hothouse conditions in the earliest Triassic of South China. Global and Planetary Change, 172: 336354. https://doi.org/10.1016/j.gloplacha.2018.10.012

Li, M., Hinnov, L.A., Huang, C. \& Ogg, J.G., 2018 a. Sedimentary noise and sea levels linked to land-ocean water exchange and obliquity forcing. Nature Communications, 9: 1004. https//doi.org/10.1038/s41467018-03454-y

Li, M., Huang, C., Hinnov, L., Chen, W., Ogg, J. \& Tian, W., 2018b. Astrochronology of the Anisian stage (Middle Triassic) at the Guandao. Earth and Planetary Science Letters, 482: 591-606. https://doi.org/10. 1016/j.epsl.2017.11.042

Liang, L., Tong, J., Song, H., Song, T., Tian, L., Song, H. \& Qiu, H., 2016. Lower-Middle Triassic conodont biostratigraphy of the Mingtang section, Nanpanjiang Basin, South China. Palaeogeography, Palaeoclimatology, Palaeoecology, 459: 381-393. https://doi.org/10.1016/j.palaeo.2016.07.027

Liu, D., Huang, C., Ogg, J.G., Kemp, D.B., Li, M., Yu, M. \& Foster, W.J., 2021. Astronomically forced changes in chemical weathering and redox during the Anisian (Middle Triassic): Implications for marine ecosystem recovery following the end-Permian mass extinction. Palaeogeography, Palaeoclimatology, Palaeoecology, 569: 110355.

https://doi.org/10.1016/j.palaeo.2021.110355

Liu, K., Xiao, W., Wilde, S.A., Zhang, J., Alexandrov, I., Kasatkin, S.A. \& Ge, M., 2021. Syn-subduction strike-slip faults shape an accretionary orogen and its provenance signatures: Insights from Sikhote-Alin in NE Asia during the Late Jurassic to Early Cretaceous. Tectonics, 40(7): e2020TC006541. https://doi.org/10. 1029/2020TC006541
Liu, X., Song, H., Bond, D.P.G., Tong, J. \& Benton, M.J., 2020. Migration controls extinction and survival patterns of foraminifers during the Permian-Triassic crisis in South China. Earth-Science Reviews, 209: 103329.

https://doi.org/10.1016/j.earscirev.2020.103329

Lozovsky, V.R., Shevyrev, A.A. \& Pyatakova, M.V., 1989. Lower Triassic ammonite and conodont zonation. Article 2. Conodont zonation. Bulletin of Moscow Society of Naturalists, Geological Series, 64(6): 44-56 [in Russian, with English abstract].

Lucas, S.G., 2010. The Triassic chronostratigraphic scale: history and status. In: Lucas, S.G. (ed.), The Triassic Timescale. Geological Society, London, Special Publications, 334: 17-39.

https://doi.org/10.1144/SP334.2

Lucas, S.G., 2007. Proxies and Triassic GSSPs. Albertiana, 36: 174-175.

Lucas, S.G., Taylor, D.G., Guex, J., Tanner, L.H. \& Krainer, K., 2007. The proposed global stratotype section and point for the base of the Jurassic System in the New York Canyon area, Nevada, USA. New Mexico Museum of Natural History and Science, Bulletin, 40: 139-168.

Lucas, S.G., 2013. A new Triassic timescale. In: Tanner, L.H., Spielmann, J.A. \& Lucas, S.G. (eds), The Triassic System. New Mexico Museum of Natural History and Science, Bulletin, 61: 366-374. https://www. researchgate.net/publication/280880292

Lucas, S.G., 2016. Base of the Rhaetian and a critique of conodont-based chronostratigraphy. Albertiana, 43: 24-32.

Lucas, S.G., 2018a. The GSSP Method of Chronostratigraphy: A Critical Review. Frontiers in Earth Science, 6: 191: 1-18. https://doi.org/10.3389/feart.2018.00191

Lucas, S.G., 2018b. The Late Triassic Timescale. In: Tanner, L.H. (ed.), The Late Triassic World. Topics in Geochronology, 46: 1-25. https://doi.org/10. 1007/978-3-319-68009-5_1

Lucas, S.G., 2018c. Late Triassic ammonoids: Distribution, Biostratigraphy and Biotic Events. In: Tanner, L.H. (ed.), The Late Triassic World. Topics in Geochronology, 46: 237-261. https://doi.org/10.1007/9783-319-68009-5_7

Lucas, S.G., 2019. Global Stratotype Section and Point (GSSP). Encyclopedia of Geology, 2nd edition, 3: 107-115. https://doi.org/10.1016/B978-0-12-4095489.11900-1

Lucas, S.G., 2020a. Rethinking the Carboniferous chronostratigraphic scale. Newsletters on Stratigraphy, 54(3): 257-274. https://doi.org/10.1127/nos/ 2020/0629

Lucas, S.G., 2020b. GSSP-based Chronostratigraphy: Should Boundaries Be Defined by Arbitrarily Chosen Non-Events ? Permophyles, 68: 9-11.

Luo, M., Buatois, L.A., Shi, G.R. \& Chen, Z.-Q., 2020. Infaunal response during the end-Permian mass ex- 
tinction. Geological Society of America Bulletin, 133(1-2): 91-99. https://doi.org/10.1130/B35524.1

Lyu, Z., Orchard, M.J., Chen, Z.-Q., Zhao, L., Zhang, L. \& Zhang, X., 2018. A Taxonomic Re-Assessment of the Novispathodus waageni Group and Its Role in Defining the Base of the Olenekian (Lower Triassic). Journal of Earth Science, 29(4): 824-836.

Lyu, Z., Orchard, M.J., Chen, Z.-Q., Henderson, C.M. \& Zhao, L., 2020. A proposed ontogenesis and evolutionary lineage of conodont Eurygnathodus costatus and its role in defining the base of the Olenekian (Lower Triassic). Palaeogeography, Palaeoclimatology, Palaeoecology, 559: 109916. https://doi.org/10.1016/j.palaeo.2020.109916

Lyu, Z., Orchard, M.J., Golding, M.L., Henderson, C.M., Chen, Z.-Q., Zhang, L., Han, C., Wu, S., Huang, Y., Zhao, L., Bhat, G.M. \& Baud, A., 2021. Lower Triassic conodont biostratigraphy of the Guryul Ravine section, Kashmir. Global and Planetary Change, Online, Pre-Proof. https://doi.org/10.1016/j. gloplacha.2021.103671

Maekawa, T., Komatsu, T. \& Koike, T., 2018. Early Triassic Conodonts from the Tahogawa Member of the Taho Formation, Ehime Prefecture, Southwest Japan. Palaeontological Society of Japan, 22: 1-62. https://doi.org/10.2517/2018PR001

Maron, M., Rigo, M., Bertinelli, A., Katz, M.E., Godfrey, L., Zaffani, M. \& Muttoni, G., 2015. Magnetostratigraphy, biostratigraphy, and chemostratigraphy of the Pignola-Abriola section: New constraints for the Norian-Rhaetian boundary. Geological Society of America Bulletin, 127 (7-8): 962-974. https://doi.org/10.1130/B31106.1

Maron, M., Muttoni, G., Rigo, M., Gianolla, P. \& Kent, D.V., 2019. New magnetostratigraphic results from the Ladinian of the Dolomites and implications for the Triassic geomagnetic polarity timescale. Palaeogeography, Palaeoclimatology, Palaeoecology, 517: 52-73. https://doi.org/10.1016/j.palaeo.2018.11.024

Maslo, M., 2008. Taxonomy and stratigraphy of the Upper Triassic heteromorphic ammonoids: preliminary results from Austria. Berichte der Geologischen Bundesanstalt, 76: 15-16.

Matsuda, T., 1983. Early Triassic Conodonts from Kashmir, India. Part 3. Neospathodus. Journal of Geosciences, Osaka City University, 26(4): 87 - 110.

Matsuda, T., 1985. Late Permian to Early Triassic conodont paleobiogeography in the "Tethys Realm". In: Nakazawa, K. \& Dickins, J.M. (eds.), The Tethys, Her Paleogeography and Paleobiostratigraphy from Paleozoic to Mesozoic: Tokai University Press, Tokyo, pp. 757-770.

Matsuda, T. \& Isozaki, Y., 1991. Well-documented travel history of Mesozoic Pelagic Chert in Japan: from remote ocean to subduction zone. Tectonics, 10: 475499.

McRoberts, C.A., 2010. Biochronology of Triassic bivalves. In: Lucas, S.G. (ed.), The Triassic Timescale.
Geological Society London, Special Publications, 334: 201-219. https://doi.org/10.1144/SP334.9

McRoberts, C.A., Krystyn, L. \& Shea, A., 2008. Rhaetian (Late Triassic) Monotis (Bivalvia: Pectinoida) from the eastern Northern Calcareous Alps (Austria) and the end-Norian crisis in pelagic faunas. Palaeontology, 51(3): 721-735. https://doi.org/10.1111/j.1475-4983.2008.00776.x

McTavish, R.A., 1973. Triassic Conodont Faunas from Western Australia. Neues Jahrbuch für Geologie und Paläontologie Abhandlungen, 143(3): 275-303.

McTavish, R.A., 1975. Triassic Conodonts and Gondwana Stratigraphy. In: Campbell, K.S.W. (ed.), Gondwana Geology, Papers presented at the Third Gondwana Symposium, Canberra, Australia. Australian National University Press, Canberra, pp. 481-490.

Meço, S., 1999. Conodont biostratigraphy of Triassic pelagic strata, Albania. Rivista Italiana di Paleontologia e Stratigrafia, 105(2): 251-266.

Meço, S., 2010. Litho-biostratigraphy and the conodonts of Palaeozoic/Triassic deposits in Albania. Palaeontographica Abteilung, A, 290(4-6): 131-197.

Mertmann, D. \& Jacobshagen, V., (2003). Upper Olenekian (Spathian) ammonoids from Chios (Lower Triassic, Greece): taxonomy and stratigraphic position. Rivista Italiana di Paleontologia e Stratigrafia, 109(3): 417-447.

Metcalfe, I., 1990a. Stratigraphic and tectonic implications of Triassic conodonts from northwest Peninsular Malaysia. Geological Magazine, 127(6): 567-578.

Metcalfe, I., 1990b. Allochthonous terrane processes in Southeast Asia. Philosophical Transactions of the Royal Society of London, A331: 625-640.

Metcalfe, I., 1998. Palaeozoic and Mesozoic geological evolution of the SE Asian region: multidisciplinary constraints and implications for biogeography. In: Hall, R. \& Holloway, J.D. (eds.), Biogeography and Geological Evolution of SE Asia. Backhuys Publishers, Amsterdam, The Netherlands, pp. 25-41. http://dx.doi.org/10.1016/j.jseaes.2012.12.020

Mietto, P. \& Manfrin, S., 1995. A high resolution Middle Triassic ammonoid standard scale in the Tethys Realm. A preliminary report. Bulletin de la Société Géologique de France, 166(5): 539-563.

Mietto, P., Fratoni, R.P. \& Perri, M.C., 1991. Spathian and Aegean conodonts from the Capelluzo Calcarenites of the Monte Facito Group (Lagonegro Sequence - Southern Apennines). Memorie di Scienze Geologiche, 43: 305-317.

Mirăuţă, E., 1974. Über die Conodontenfauna des oberen Werfens des tieferen Anis der nördlichen Dobrudscha/Rumänien. Geologica et Paleontologica, 8: 149-158.

Mirăuţă, E. \& Gheorghian, D., 1978. Étude microfaunique des formations triasiques (transylvaines, bucoviniennes et getiques) des Carpates Orientales. Dări de seamă ale Şedinţelor, Institutul de Geologie şi Geofizică, 64/3 : 109-162. 
Mirăuţă, E., Iordan, M. \& Gheorghian, D., 1984. New biostratigraphic data on the Triassic from the Somova-Sarica hill area (Tulcea Zone, North Dobrogea). Dări de seamă ale Ședinţelor, Institutul de Geologie şi Geofizică, 68/4 : 35-48.

Mojsisovics, E. v., Waagen, W. \& Diener, C., 1895. Entwurf einer Gliederung der pelagischen Sedimente des Trias-Systems. Sitzungsberichte der Kaiserlichen Akademie der Wissenschaften, MathematischNaturwissenschaftliche Classe, 105(1): 1271-1302.

Monnet, C. \& Bucher, H., 2005. New Middle and Late Anisian (Middle Triassic) ammonoid fauna from northwestern Nevada (USA) : taxonomy and biochronology. Fossils and Strata, 52: 1-121.

Monnet, C. \& Bucher, H., 2006. Anisian (Middle Triassic) ammonoids from North America: quantitative biochronology and biodiversity. Stratigraphy, 2(4): 281296.

Monnet, C., Bucher, H., Brayard, A. \& Jenks, J.F., 2013. Globacrochordiceras gen. nov. (Acrochordiceratidae, late Early Triassic) and its significance for stressinduced evolutionary jumps in ammonoid lineages (cephalopods). Fossil Record, 16(2): 197-215.

Mosher, L.C., 1968. Triassic conodonts from western North America and Europe and their correlation. Journal of Paleontology, 42(4): 895 - 946.

Muto, S., 2021. Recurrent deposition of organic-rich sediments in Early Triassic pelagic Panthalassa and its relationship with global oceanic anoxia: New data from Kyoto, Southwest Japan. Global and Planetary Change, 197: 103402.

https://doi.org/10.1016/j.gloplacha.2020.103402

Muto, S., Takahashi, S., Yamakita, S., Suzuki, N., Suzuki, N. \& Aita, Y., 2018. High sediment input and possible oceanic anoxia in the pelagic Panthalassa during the latest Olenekian and early Anisian: Insights from a new deep-sea section in Ogama, Tochigi, Japan. Palaeogeography, Palaeoclimatology, Palaeoecology, 490: 687-707. https://doi.org/10.1016/j.palaeo.2017. 11.060

Muto, S., Takahashi, S., Yamakita, S., Soda, K. \& Onoue, T., 2019. Conodont-based age calibration of the Middle Triassic Anisian radiolarian biozones in pelagic deep-sea bedded chert. Bulletin of the Geological Survey of Japan, 70(1/2): 43-89. https://doi.org/10.9795/bullgsj.70.43

Muto, S., Takahashi, S., Yamakita, S. \& Onoue, T., 2020. Scarcity of chert in upper Lower Triassic Panthalassic deep-sea successions of Japan records elevated clastic inputs rather than depressed biogenic silica burial flux following the end-Permian extinction. Global and Planetary Change, 195: 103330. https://doi.org/10. 1016/j.gloplacha.2020.103330

Muttoni, G., Kent, D.V. \& Gaetani, M., 1994. The base of the Anisian. A candidate Global Stratotype Section and Point from Chios Island (Greece). Albertiana, 13: 37-42.
Muttoni, G., Kent, D.V. \& Gaetani, M., 1995. Magnetostratigraphy of a Lower-Middle Triassic boundary section from Chios (Greece). Physics of the Earth and Planetary Interiors, 92: 245-260. https://doi.org/10.1016/0031-9201(95)03021-4

Muttoni, G., Kent, D.V., Meço, S., Nicora, A., Gaetani, M., Balini, M., Germani, D. \& Rettori, R., 1996. Magnetostratigraphy of the Spathian to Anisian (Lower to Middle Triassic) Kçira section, Albania. Geophysical Journal International, 127: 503-514. https://doi.org/10.1111/j.1365-246X.1996.tb04736.x

Muttoni, G., Kent, D.V., Meço, S., Nicora, A., Rettori, R., Gaetani, M. \& Krystyn, L., 1998. Towards a better definition of the Middle Triassic magnetostratigraphy and biostratigraphy in the Tethyan realm. Earth and Planetary Science Letters, 164: 285-302. https://doi.org/10.1016/S0012-821X(98)00215-5

Muttoni, G., Kent, D.V., Olsen, P.E., Di Stefano, P., Lowrie, W., Bernasconi, S.M. \& Hernández, F.M., 2004. Tethyan magnetostratigraphy from Pizzo Mondello (Sicily) and correlation to the Late Triassic Newark astrochronological polarity time scale. Geological Society of America Bulletin, 116(9-10): 10431058. https://doi.org/10.1130/B25326.1

Muttoni, G., Kent, D.V., Jadoul, F., Olsen, P.E., Rigo, M., Galli, M.T. \& Nicora A., 2010. Rhaetian magneto-biostratigraphy from the Southern Alps (Italy): Constraints on Triassic chronology. Palaeogeography, Palaeoclimatology, Palaeoecology, 285: 1-16. https://org.doi/10.1016/j.palaeo.2009.10.014

Muttoni, G., Nicora, A., Balini, M., Katz, M., Schaller, M., Kent, D.V., Maron, M., Meço, S., Rettori, R., Doda, V. \& Nazaj, S., 2019. A candidate GSSP for the base of the Anisian from Kçira, Albania. Albertiana, 45: 39-49.

Nakazawa, K. \& Bando, Y., 1968. Lower and Middle Triassic Ammonites from Portuguese Timor (Palaeontological Study of Portuguese Timor, 4). Memoirs of the Faculty of Science, Kyoto University, Series of Geology \& Mineralogy, 34(2): 83-114.

Nakazawa, K., Kapoor, H.M., Ishii, K., Bando, Y., Okimura, Y., Tokuoka, T., Murata, M., Nakamura, K., Nogami, Y., Sakagami, S. \& Shimizu, D., 1975. The Upper Permian and the Lower Triassic in Kashmir, India. Memoirs of the Faculty of Science, Kyoto University, Series of Geology \& Mineralogy, 42(1): 1106.

Nakazawa, K., Ishibashi, T., Kimura, T., Koike, T., Shimizu, D. \& Yao, A., 1994. Triassic biostratigraphy of Japan based on various taxa. In: Guex, J. \& Baud, A. (eds.), Recent developments on Triassic stratigraphy (Proceedings of the Triassic Symposium, Lausanne, 20-23 Oct. 1991). Mémoires de Géologie (Lausanne), 22: 83-101.

Nakrem, H.A., Orchard, M.J., Weitschat, W., Hounslow, M.W., Beatty, T.W. \& Mørk, A., 2008. Triassic conodonts from Svalbard and their Boreal correlations. 
Polar Research, 27: 523-539. https://doi.org/10. 1111/j.1751-8369.2008.00076.x

Nicoll, R.S., 2002. Conodont biostratigraphy and palaeogeography of the Triassic on the western, northwestern and northern margins of the Australian Plate. In: Keep, M. \& Moss, S.J. (eds.), The Sedimentary Basins of Western Australia, 3: Proceedings of the Petroleum Exploration Society of Australia Symposium, Perth, W.A., 2002, pp. 167-177.

Nicoll, R.S. \& Foster, C.B., 1998. Revised ConodontPalynomorph Biostratigraphic Zonation and the Stratigraphy of the Triassic of the Western and Northwestern Margins of Australia and Timor. In: Purcell, P.G. \& Purcell, R.R. (eds.), Sedimentary Basins of Western Australia, 2: Proceedings of Petroleum Exploration Society Australia Symposium, Perth, 1998, pp. 129-139.

Nicoll, R.S., Orchard, M.J. \& Campbell, H., 2007. Conodont biostratigraphy and paleogeography of the Triassic of the Australian Plate and the accreted terranes of New Zealand. In: Lucas, S.G. \& Spielmann, J.A. (eds.), The Global Triassic. New Mexico Museum of Natural History and Science Bulletin, 41: 316-317.

Nicora, A., 1977. Lower Anisian platform-conodonts from Tethys and Nevada: taxonomic and stratigraphic revision. Palaeontographica Abt. A, 157: 88-107.

Nielsen, J.K., Shen, Y., Piasecki, S. \& Stemmerik, L., 2010. No abrupt change in redox condition caused the end-Permian marine ecosystem collapse in the East Greenland Basin. Earth and Planetary Science Letters, 291(1-4): 32-38. https://doi.org/10.1016/j.epsl. 2009.12.043

Nogami, Y., 1968. Trias-Conodonten von Timor, Malaysien und Japan (Palaeontological Study of Portuguese Timor, 5). Memoirs of the Faculty of Science, Kyoto University, Series of Geology and Mineralogy, 34(2): 115-136.

Nokleberg, W.J., Parfenov, L.M., Monger, J.W.H., Baranov, B.V., Byalobzhesky, S.G., Bundtzen, T.K., Feeney, T.D., Fujita, K., Gordey, S.P., Grantz, A., Khanchuk, A.I., Natal'in, B.A., Natapov, L.M., Norton, I.O., Patton, W.W. Jr., Plafker, G., Scholl, D.W., Sokolov, S.D., Sosunov, G.M., Stone, D.B., Tabor, R.W., Tsukanov, N.V., Vallier, T.L. \& Wakita, K., 1994. Circum-North Pacific tectono-stratigraphic terrane map. U.S. Geological Survey Open-File Report 94-714, 2 sheets, scale 1:5,000,000; 2 sheets, scale $1: 10,000,000,211 \mathrm{pp}$.

Ogg, J.G., 2004. The Triassic Period. In: Gradstein, F.M., Ogg, J.G. \& Smith, A.L. (eds.), A Geologic Time Scale 2004. Cambridge University Press, Cambridge, pp. 271-306.

Ogg, J.G., 2012. Triassic. In: Gradstein, F.M., Ogg, J.G., Schmitz, M.D. \& Ogg, G.M. (eds.), The Geologic Time Scale 2012. Elsevier, Boston, USA, pp. 681730 .

https://doi.org/10.1016/B978-0-444-59425-9.00025-1
Ogg, J.G., 2019. Publication Announcement: EarlyMiddle Triassic boundary interval: Integrated chemobio-magneto-stratigraphy of potential GSSPs for the base of the Anisian Stage in South China. By Yan Chen, Haishui Jiang, James G. Ogg, Yang Zhang, Yifan Gong \& Chunbo Yan, 2019. Earth and Planetary Science Letters, [access on-line 23 Oct 2019]. https://doi.org/10.1016/j.epsl.2019.115863. Albertiana, 45: 7-73.

Ogg, J.G, Huang, C. \& Hinnov, L., 2014. Triassic timescale status: A brief overview. Albertiana, 41: 3-30.

Ogg, J.G., Ogg, G.M. \& Gradstein, F.M., 2016. A Concise Geologic Time Scale 2016. Elsevier, 234 pp.

Ogg, J.G., Grădinaru, E., Chen, Y., Bucher, F.R., Lucas, S.G. \& Hounslow, M.W., 2020a, Comments on defining the base of Anisian Stage. Research Gate: https://www.researchgate.net/publication/336767153_ Early-Middle_Triassic_boundary_interval_ Integrated_chemo- bio- magneto-stratigraphy_of_potential_ GSSPs_ for_the_base_of the_Anisian_Stage_in_ South_China/comments.

Ogg, J.G., Chen, Z.-Q., Orchard, M.J. \& Jiang, H.S., 2020b. The Triassic period. In: Gradstein, F.M., Ogg, J. G., Schmitz, M. \& Ogg, G.M. (eds.), Geologic Time Scale 2020, 1st Edition. Elsevier, pp. 903-953. https://doi.org/10.1016/B978-0-12-824360-2.00025-5

Orchard, M.J., 1991. Conodonts, time and terranes: an overview of the biostratigraphic record in the western Canadian Cordillera. In: Orchard, M.J. \& McCracken, A.D. (eds.), Ordovician to Triassic conodont paleontology of the Canadian Cordillera. Geological Survey of Canada Bulletin, 417: 1-25.

Orchard, M.J., 1994a. Conodont biochronology around the Early-Middle Triassic boundary: new data from North America, Oman and Timor. In: Guex, J. \& Baud, A. (eds.), Recent developments on Triassic stratigraphy. Proceedings of the Triassic Symposium, Lausanne, 20-23 Oct. 1991). Mémoires de Géologie (Lausanne), 22: 105-114.

Orchard, M.J., 1994b. Conodonts from Otoceras Beds: are they Permian? Albertiana, 13: 8-11.

Orchard, M.J., 1995. Taxonomy and correlation of Lower Triassic (Spathian) segminate conodonts from Oman and revision of some species of Neospathodus. Journal of Paleontology, 69(1): 110-122. https://doi. org/10.1017/S0022336000026962

Orchard, M.J., 2005. Multielement conodont apparatuses of Triassic conodonts. Special Papers in Palaeontology, 73: 73-101.

Orchard, M.J., 2010. Triassic conodonts and their role in stage boundary definitions. In: Lucas, S.G. (ed.), The Triassic Timescale. The Geological Society, London, Special Publication, 334: 139-161. https://doi.org/10. 1144/SP334.7

Orchard, M.J., 2016. Base of the Rhaetian and a critique of Triassic conodont-based chronostratigraphy: comment. Albertiana, 43: 28-32. 
Orchard, M.J. \& Bucher, H., 1992. Conodont-ammonoid intercalibration around the Lower-Triassic boundary: Nevada clocks help tell British Columbian time. Current Research, Part E; Geological Survey of Canada, Paper 92-IE: 133-140.

Orchard, M.J. \& Tozer, E.T., 1997a. Triassic conodont biochronology, its intercalibration with the ammonoid standard, and a biostratigraphic summary for the western Canada Sedimentary Basin. In: Moslow, T. \& Wittenberg, J. (eds.), Triassic of Western Canada Basin. Bulletin of Canadian Petroleum Geology, 45: 675-692.

Orchard, M.J. \& Tozer, E.T., 1997b. Triassic conodont biochronology and intercalibration with the Canadian ammonoid sequence. Albertiana, 20: 33-44.

Orchard, M.J., Grădinaru, E. \& Nicora, A., 2007a. A summary of the conodont succession around the Olenekian-Anisian boundary at Deşli Caira, North Dobrogea, Romania. New Mexico Museum Natural History Science Bulletin, 41: 341-346.

Orchard, M.J., Lehrmann, D.J., Wie, J., Wang, H. \& Taylor, H.J., 2007b. Conodonts from the OlenekianAnisian boundary beds, Guandao, Guizhou Province, China. New Mexico Museum Natural History Science Bulletin, 41: 347-354.

Ovtcharova, M., Bucher, H., Schaltegger, U., Galfetti, T., Brayard, A. \& Guex, J., 2006. New Early to Middle Triassic U-Pb ages from South China: Calibration with ammonoid biochronozones and implications for the timing of the Triassic biotic recovery. Earth and Planetary Science Letters, 243: 463-475. https://doi.org/10.1016/j.epsl.2006.01.042

Ovtcharova, M., Bucher, H., Goudemand, N., Schaltegger, U., Brayard, A. \& Galfetti, T., 2010. New U/Pb ages from Nanpanjiang Basin (South China): implications for the age and definition of the Early-Middle Triassic boundary. Geophysical Research Abstracts, 12: EGU2010-12505-3

Ovtcharova, M., Goudemand, N., Hammer, Ø., Guodun, K., Cordey, F., Galfetti, T., Schaltegger, U. \& Bucher, H., 2015. Developing a strategy for accurate definition of a geological boundary through radio-istopic and biochronological dating: The Early-Middle Triassic boundary (South China). Earth-Science Reviews, 146: 65-76. https://doi:org/10.1016/j.earscirev.2015.03.006

Pakistani-Japanese Research Group, 1985. Permian and Triassic systems in the Salt Range and Surghar Range, Pakistan. In: Nakazawa, K. \& Dickins, J.M. (eds.), The Tethys, Her Paleogeography and Palaeobiogeography from Paleozoic to Mesozoic.Tokyo, Tokai University Press, pp. 219-312.

Patrulius, D., Mirăuță, E. \& Gheorghian, D., 1996. The Klippen of the Perşani Mountains (East Carpathians). Memoriile Institutului Geologic al României, 36: 3152.

Paull, R.K., 1988. Distribution Pattern of Lower Triassic (Scythian) Conodonts in the Western United States:
Documentation of the Pakistan Connection. Palaios, 3(6): 598-605.

http://dx.doi.org/10.2307/3514448

Paull, R.K. \& Paull, R.A., 1994. Hindeodus parvus as the index fossil for the Permian-Triassic Boundary: a response to the Chinese Working Group. Albertiana, 13: 3-7.

Paull, R.K. \& Paull, R.A., 1998. Age and Regional Significance of Marine Triassic Rocks at O’Neil Pass, Northeastern Nevada. The Mountain Geologist, 35(3): 103-113.

Parfenov, L.M., Badarch, G., Berzin, N.A., Khanchuk, A.I., Kuzmin, M.I., Nokleberg, W.J., Prokopiev, A.V., Ogasawara, M. \& Yan, H., 2009: Summary of Northeast Asia geodynamics and tectonics. Stephan Mueller Special Publication Series, 4: 11-33. www.stephan-mueller-spec-publ-ser.net/4/11/2009/

Pia, J. v., 1930. Grundbegriffe der Stratigraphie mit ausführlicher Anwendung auf die europäische Mitteltrias. Leipzig und Wien. 252 pp.

Plasencia, P., Márquez-Aliaga, A. \& Sha, J., 2013. A data base of Triassic conodonts from a comprehensive revision of literature. Spanish Journal of Palaeontology, 28(2): 215-226.

Qin, B., Golding, M.L., Jiang, H., Chen, Y., Zhang, M., Kang, L., Wang, D. \& Yuan, J., 2021. Middle Triassic (Anisian) Conodont Biostratigraphy at the Shaiwa Section, Guizhou, South China. Journal of Earth Science, 32(3): 592-615. https://doi.org/10.1007/s12583021-1477-0

Racki, G., 2021. Big 5 Mass Extinctions. In: Alderton, D. \& Elias, S.A. (eds.), Encyclopedia of Geology, 2nd ed., Elsevier, 3: 603-616. https://doi.org/10.1016/B978-0-12-409548-9.12028-7

Renz, C. \& Renz, O., 1948. Eine untertriadische Ammonitenfauna von der griechischen Insel Chios. Schweizerische Paläontologische Abhandlungen, 66: 3-98.

Rigo, M., Bertinelli, A., Concheri, G., Gattolin, G., Godfrey, L., Katz, M., Maron, M., Muttoni, G., Sprovieri, M., Stellin, F. \& Zaffani, M., 2015. The Pignola-Abriola section (southern Apennines, Italy): a new GSSP candidate for the base of the Rhaetian Stage. Lethaia, 49(3): 287-306. https://doi. org/10.1111/let.12145

Rosenberg, G., 1952. Vorlage einer Schichtennamentabelle der Nord- und Sudalpinen Mitteltrias der Ostalpen. Mitteilungen der Geologischen Gesellschaft in Wien, 42-43: 235-247.

Rosenberg, G., 1959. Geleitworte zu den Tabellen der Nord- und Südalpinen Trias der Ostalpen. Jahrbuch der Geologischen Bundesanstalt, 102: 477-479.

Schoepfer, S.D., Henderson, C.M., Garrison, G.H., Foriel, J., Ward, P.D., Selby, D., Hower, J.C., Algeo, T.J. \& Shen, Y., 2013. Termination of a continent-margin upwelling system at the Permian-Triassic boundary (Opal Creek, Alberta, Canada). Global and Planetary 
Change, 105: 21-35.

https://doi.org/10.1016/j.gloplacha.2012.07.005

Scotese, C.R., 2014. Atlas of Middle \& Late Permian and Triassic Paleogeographic Maps, maps 43 - 48 from Volume 3 of the PALEOMAP Atlas for ArcGIS (Jurassic and Triassic) and maps $49-52$ from Volume 4 of the PALEOMAP PaleoAtlas for ArcGIS (Late Paleozoic), Mollweide Projection, PALEOMAP Project, Evanston, IL.

Shen, J., Schoepfer, S.D., Feng, Q., Zhou, L., Yu, J., Song, H., Wei, H. \& Algeo, T.J., 2015. Marine productivity changes during the end-Permian crisis and Early Triassic recovery. Earth-Science Reviews, 149: 136-162. https://doi.org/10.1016/j.earscirev.2014.11.002

Shen, J., Chen, J., Algeo, T.J., Feng, Q., Yu, J., Xu, Y.G., Xu, G., Lei, Y., Planavsky, N.J. \& Xie, S., 2021. Mercury fluxes record regional volcanism in the South China craton prior to the end-Permian mass extinction. Geology, 49(4): 452-456. https://doi.org/ $10.1130 / \mathrm{G} 48501.1$

Shevyrev, A.A., 1968. Triassic ammonoids of southern U.S.S.R. Transactions of Paleontological Institute, USSR Academy of Sciences, Moscow, 119, 272 pp. [in Russian].

Shevyrev, A.A., 1986. Triassic ammonoids. Transactions of Paleontological Institute, USSR Academy of Sciences, Moscow, 217, 184 pp. [in Russian].

Shevyrev, A.A., 1990. Ammonoids and chronostratigraphy of the Triassic. Transactions of Paleontological Institute, USSR Academy of Sciences, Moscow, 241, 179 pp. [in Russian].

Shevyrev, A.A., 1995. Triassic ammonites of northwestern Caucasus. Transactions of Paleontological Institute, Russian Academy of Sciences, Moscow, 264, 174 pp. [in Russian].

Shevyrev, A.A., 1996. Stratigraphy of North Caucasus Triassic on ammonoids. Stratigraphic and Geological Correlation, 4(2): 1-27.

Shevyrev, A.A., 2000. Anisian ammonoid biostratigraphy of the northwestern Caucasus. In: Grădinaru, E. (ed.), Workshop on the Lower-Middle Triassic (OlenekianAnisian) boundary, 7-10 June, 2000, Tulcea, Romania. Conference Section, pp. 56-59.

Shevyrev, A. A., 2006. Triassic biochronology: state of the art and main problems. Stratigraphy and Geological Correlation, 14: 629-641.

Silberling, N.J. \& Tozer, E.T., 1968. Biostratigraphic Classification of the Marine Triassic in North America. Geological Society of America Special Paper, 110, 63 pp., Boulder.

Silberling, N.J. \& Wallace, R.E., 1969. Stratigraphy of the Star Peak Group (Triassic) and overlying lower Mesozoic rocks, Humboldt Range, Nevada. U.S. Geological Survey Profesional Paper, 592: 1-50.

Silberling, N.J. \& Nichols, K.M., 1982. Middle Triassic molluscan fossils of biostratigraphic significance from the Humboldt Range, north-western Nevada. U.S. Geological Survey Professional Paper, 1207: 1-77.

Silberling, N.J., Jones, D.L., Blake, M.C., Jr. \& Howell, D.G., 1984. Lithotectonic terrane map of the western conterminous United States. In: Silberling, N.J. \& Jones, D.L. (eds.), Lithotectonic terrane maps of the North American Cordillera. U.S. Geological Survey Open-File Report 84-523, Pt. C, 43 pp.

Silberling, N.J., Jones, D.L., Monger, J.W.H. \& Coney, P.J., 1992. Lithotectonic terrane map of the North American Cordillera. U.S. Geological Survey Miscellaneous Investigations Series, Map 1-2176, 2 sheets, scale 1:5,000,000.

Silberling, N.J., Grant-Mackie, J.A. \& Nichols, K.M., 1997. The Late Triassic bivalve Monotis in accreted terranes of Alaska. U.S. Geological Survey Bulletin, 2151, $21 \mathrm{pp}$.

Sobolev, E.S. \& Klets, T.V., 2009. New data on conodonts and biostratigraphy of the Lower and Middle Triassic of Eastern Taimyr (north of Middle Siberia). Paleontology and improvement of the stratigraphic basis of geological mapping. Proceedings of the 55th Session of the Paleontological Society of the Russian Academy of Sciences (April 6-10, 2009, St. Petersburg), pp. 137-138 [in Russian].

Solien, M.A., 1979. Conodont biostratigraphy of the Lower Triassic Thaynes Formation, Utah. Journal of Paleontology, 53(2): 276-306.

Song, H., Tong, J., Algeo, T.J., Horacek, M., Qiu, H., Song, H., Tian, L. \& Chen, Z.-Q., 2013. Large vertical $\delta^{13} C_{\text {DIC }}$ gradients in Early Triassic seas of the South China craton: Implications for oceanographic changes related to Siberian Traps volcanism. Global and Planetary Change, 105: 7-20. http://dx.doi.org/10.1016/j.gloplacha.2012.10.023

Song, H., Wignall, P.B. \& Dunhill, A.M., 2018. Decoupled taxonomic and ecological recoveries from the Permo-Triassic extinction. Science Advance, 4(10): eaat5091. https://doi.org/10.1126/sciadv.aat5091

Song, H., Song, H., Tong, J., Gordon, G.W., Wignall, P.B., Tian, L., Zheng, W., Algeo, T.J., Liang, L., Bai, R., Wu, K. \& Anbar, A.D., 2021. Conodont calcium isotopic evidence for multiple shelf acidification events during the Early Triassic. Chemical Geology, 562: 120038 .

https://doi.org/10.1016/j.chemgeo.2020.120038

Spath, L.F., 1934. The Ammonoidea of the Trias. Catalogue of the Fossil Cephalopoda in the British Museum (Natural History), Part 4, London, 521 pp.

Stone, P., Stevens, C.H. \& Orchard, M.J., 1991. Stratigraphy of the Lower and Middle(?) Triassic Union Wash Formation, East-Central California. U.S. Geological Survey Bulletin, 1928: 1-26.

Sun, Y.D., Richoz, S., Krystyn, L., Grasby, S.E., Chen, Y.L., Banerjee, D. \& Joachimski, M.M., 2021. Integrated bio-chemostratigraphy of Lower and Middle Triassic marine successions at Spiti in the Indian 
Himalaya: Implications for the Early Triassic nutrient crisis. Global and Planetary Change, 196: 103363. https://doi.org/10.1016/j.gloplacha.2020.103363

Sweet, W.C., 1970a. Uppermost Permian and Lower Triassic conodonts of the Salt Range and Trans-Indus Ranges, West Pakistan, In: Kummel, B. \& Teichert, C. (eds.), Stratigraphic Boundary Problems, Permian and Triassic of West Pakistan. Department of Geology, University of Kansas, Special Publication, 4: 207275.

Sweet, W.C., 1970b. Permian and Triassic conodonts from a section at Guryul Ravine, Vihi District, Kashmir. University of Kansas, Paleontological Contributions, Paper 49: 1-10.

Sweet, W.C., 1973. Genus Neospathodus Mosher, 1968. In: Ziegler, W. (ed.), Catalogue of Conodonts. I. E. Schweizerbart'sche Verlagsbuchhandlung, Stuttgart, pp. 155-194.

Sweet, W.C., 1988. A quantitative conodont biostratigraphy for the Lower Triassic. Senkenbergiana lethaea, 69(3-4): 253-273.

Sweet, W.C. \& Bergström, S.M., 1986. Conodonts and biostratigraphic correlation. Annual Review of Earth and Planetary Sciences, 14: 85-112.

Sweet, W.C., Mosher, L.C., Clark, D.L., Collinson, J.W. \& Hasenmueller, W.H., 1971. Conodont biostratigraphy of the Triassic. In: Sweet, W.C. \& Bergstrom, S.M. (eds.), Symposium on Conodont Biostratigraphy. Geological Society of America Memoir, 127: 441-465.

Taylor, D., Guex, J. \& Lucas, S.G., 2021. Ammonoids of the latest Triassic Gabbs Formation at New York Canyon, Mineral County, Nevada. In: Lucas, S. G., Hunt, A. P. \& Lichtig, A. J. (eds.), Fossil Record 7. New Mexico Museum of Natural History and Science Bulletin, 82: 393-425.

Tian, C.-R., 1982. Triassic Conodonts in the Tulong Section from Nyalam County, Xizang (Tibet), China. Contribution to the Geology of the Qinghai-Xizang (Tibet) Plateau. 10: 153-165 [in Chinese, with English abstract].

Tong, J., Zakharov, Y.D., Orchard, M.J., Yin, H. \& Hansen, H.J., 2003. A candidate of the Induan-Olenekian boundary stratotype in the Tethyan region. Science in China (Series D), 46(11): 1182-1200. https://doi.org/10.1360/03yd0295

Tong, J., Zakharov, Y.D., Orchard, M.J., Yin, H. \& Hansen, H.J., 2004a. Proposal of Chaohu Section as the GSSP candidate of the Induan-Olenekian boundary. Albertiana, 29:13-28.

Tong, J., Zakhraov, Y.D., \& Wu, S., 2004b. Early Triassic ammonoid succession in Chaohu, Anhui Province. Acta Palaeontologica Sinica, 43: 192-204.

Tong, J., Chu, D., Liang, L., Shu, W., Song., H., Song, T., Song, H. \& Wu, Y., 2019. Triassic integrative stratigraphy and timescale of China. Science China Earth Sciences, 62(1): 189-222. https://doi.org/10.1007/ s11430-018-9278-0
Tozer, E.T., 1965. Lower Triassic stages and ammonoid zones of Arctic Canada. Geological Survey of Canada Paper, 65(12): 1-14.

Tozer, E.T., 1967. A Standard for Triassic Time. Geological Survey of Canada, Bulletin 156, 103 pp.

Tozer, E.T., 1971. Triassic Time and Ammonoids: Problems and Proposals. Canadian Journal of Earth Sciences, 8(8): 989-1031.

Tozer, E.T., 1974. Definitions and Limits of Triassic Stages and Substages: Suggestions Prompted by Comparisons Between North America and the AlpineMediterranean Region. In: Zapfe, H. (ed.), Die Stratigraphie der alpin-mediterranen Trias - The Stratigraphie of the Alpine-Mediterranean Triassic. Schriftenreiche der Erdwissenschaftlichen Kommissionen, Österreichische Akademie der Wissenschaften, 2:195206.

Tozer, E.T., 1978. Review of the Lower Triassic Ammonoid Succession and its Bearing on Chronostratigraphic Nomenclature. In: Zapfe, H. (ed.), Biträge zur Biostratigraphie der Tethys-Trias. Schriftenreiche der Erdwissenschaftlichen Kommissionen, Österreichische Akademie der Wissenschaften, 4: 21-36.

Tozer, E.T., 1980. Triassic Ammonoidea: Classification, Evolution and Relationships with Permian and Jurassic Forms. In: House, R.M. \& Senior, J.R. (eds.), The Ammonoidea, Systematics Association Special Volume, 18: 66-100. Academic Press, London and New York.

Tozer, E.T., 1982. Marine Triassic Faunas of North America: Their Significance for Assessing Plate and Terrane Movements. Geologische Rundschau, 71(3): 1077-1104.

Tozer, E.T., 1984. The Trias and its Ammonites: the evolution of a time scale. Geological Survey of Canada Miscellaneous Report, 35, 171 pp.

Tozer, E.T., 1994a. Canadian Triassic ammonoid faunas. Geological Survey of Canada Bulletin, 467: 663 pp.

Tozer, E.T., 1994b. Age and correlation of the Otoceras beds at the Permian-Triassic boundary. Albertiana, 14: 31-37.

Tozer, E.T., 1994c. Significance of Triassic stage boundaries defined in North America. In: Guex, J. \& Baud, A. (eds.), Recent developments on Triassic stratigraphy (Proceedings of the Triassic Symposium, Lausanne, 20-23 Oct. 1991). Mémoires de Géologie (Lausanne), 22: 155-170

Tozer, E.T., 2003. Interpretation of the Boreal Otoceras Beds: Permian or Triassic ? Albertiana, 28: 90-91.

Vishnevskaya, V. \& Filatova, N., 1994. Mesozoic terranes of the northwest Pacific continental margins (Russia): Radiolarian ages and sedimentary environments. The Island Arc, 3: 199-220.

Wakita, K. \& Metcalfe, I., 2005. Ocean Plate Stratigraphy in East and Southeast Asia. Journal of Asian Earth Sciences, 24: 679-702. https://doi.org/ 10.1016/j. jseaes.2004.04.004 
Wang, Y.-G., 1978. Latest Early Triassic ammonoids of Ziyun, Guizhou - with notes on the ralationships between Early and Middle Triassic ammonoids. Acta Palaeontologica Sinica, 17(2): 151-179.

Wang, Y.-G., 1985. Remarks on the Scythian-Anisian boundary. Rivista Italiana di Paleontologia e Stratigrafia, 90(4): 515-544.

Wang, Z.-H., 1982. Discovery of Early Triassic Neospathodus timorensis fauna in Ziyun of Guizhou. Acta Palaeontologica Sinica, 21(5): 584-587 [in Chinese, with English abstract].

Wang, C.-Y. \& Wang, Z.-H., 1983. Review of conodont biostratigraphy in China. Fossils and Strata, 15: 2933.

Wang, H.M., Wang, X.L., Li, R.X. \& Wei, J.Y., 2005. Triassic conodont succession and stage subdivision of the Guandao Section, Bianyang, Luodian, Guizhou. Acta Palaeontologica Sinica, 44 (4): 611-626 [in Chinese, with English abstract].

Wardlaw, B.R. \& Jones, D.S., 1980. Triassic conodonts from eugeoclinal rocks of western North America and their tectonic significance. Rivista Italiana di Paleontologia, 85(3-4): 895-908.

Watanabe, K., Kanmera, K. \& Nakajima, K., 1979. Conodont Biostratigraphy in the Kamura Limestone (Triassic), Takachiho-cho, Nishiusuki-gun, Miyazaki Prefecture. In: Igo, H. \& Koike, T. (eds.), Biostratigraphy of Permian and Triassic Conodonts and Holothurian Sclerites in Japan. Memoir Volume Prof. Mosaburo Kanuma, Tokyo, Japan, pp. 127-137 [in Japanese].

Wei, H., Zhang, X. \& Qiu, Z., 2020. Millennial-scale ocean redox and $\delta^{13} \mathrm{C}$ changes across the PermianTriassic transition at Meishan and implications for the biocrisis. International Journal of Earth Sciences, 109: 1753-1766. https://doi.org/10.1007/ s00531-020-01869-x

Weitschat, W. \& Dagys, A.S., 1989. Triassic biostratigraphy of Svalbard and a comparison with NESiberia. Mitteilungen aus dem GeologischPaläontologischen Institut der Universität Hamburg, 68: 179-213.

Wignall, P.B. \& Twitchett, R.J., 2002. Extent, duration, and nature of the Permian-Triassic superanoxic event. In: Koeberl, C. \& MacLeod, K.C. (eds.), Catastrophic Events and Mass Extinction: Impacts and Beyond. Geological Society of America Special Paper, 356: 395-413. https://doi.org/10.1130/0-8137-2356-6.395

Wignall, P.B., Bond, D.P.G., Kuwahara, K., Kakuwa, Y., Newton, R.J. \& Poulton, S.W., 2010. An 80 million years oceanic redox history from Permian to Jurassic pelagic sediments of the Mino-Tamba terrane, SW Japan, and the origin of four mass extinctions. Global and Planetary Change, 71: 109-123. https://doi.org/10.1016/j. gloplacha.2010.01.022

Wu, G.-C., Yao, J.-X. \& Ji, Z.-S., 2007. Triassic conodont biostratigraphy in the Coqên area, western
Gangdise, Tibet, China. Geological Bulletin of China, 26(8): 938-946 [in Chinese, with English abstract].

Wu, K., Tian, L., Liang, L., Metcalfe, I., Chu, D. \& Tong, J., 2019. Recurrent biotic rebounds during the Early Triassic: biostratigraphy and temporal size variation of conodonts from the Nanpanjiang Basin, South China. Journal of the Geological Society, 176: 12321246. https://doi.org/10.1144/jgs2019-065

Wu, H.-T., Zhang, Y. \& Sun, Y.-L., 2019. A mixed Permian-Triassic boundary brachiopod fauna from Guizhou Province, South China. Rivista Italiana di Paleontologia e Stratigrafia, 125(3): 609-630. https://doi.org/10.13130/2039-4942/12162

Wu, S., Chen, Z.-Q., Fang, Y., Pei, Y., Yang, H. \& Ogg. J., 2017. A Permian-Triassic boundary microbialite deposit from the easternYangtze Platform (Jiangxi Province, South China): Geobiologic features, ecosystem composition and redox conditions. Palaeogeography, Palaeoclimatology, Palaeoecology, 486: 58-73. http://dx.doi.org/10.1016/j.palaeo.2017.05.015

Yan, C., Jiang, H., Lai, X., Sun, Y., Yang, B. \& Wang, L., 2015. The Relationship between the "Green-Bean Rock" Layers and Conodont Chiosella timorensis and Implication on Defining the Early-Middle Triassic Boundary in the Nanpanjiang Basin, South China. Journal of Earth Science, 20(2): 236-245. https://doi.org/10.1007/s12583-015-0535-X

Yao, J.X., Ji, Z.S., Wang, L.T., Wang, Y.B. \& Wu, G.C., 2004. Research on Conodont Biostratigraphy near the Bottom Boundary of the Middle Triassic Qingyan Stage in Southern Guizhou Province. Acta Geologica Sinica, 78(5): 577-585 [in Chinese, with English abstract].

Yao, J.X., Ji., Z.S., Wang., L.T., Wang, Y.B., Wu, Z.J., Liu, D.Y., Wu, G.C., Zhang, J.W. \& Li, S.P., 2011. Conodont Biostratigraphy and Age Determination of the Lower-Middle Triassic Boundary in South Guizhou Province, China. Acta Geologica Sinica (English Edition), 85(2): 408-420. https://doi.org/10.1111/j.1755-6724.2011.00409.x

Yin, H., 1993. A proposal for the global stratotype section and point (GSSP) of the Permian-Triassic boundary (Chinese Working Group on the PermianTriassic Boundary). Albertiana, 11: 4-30.

Yin, H., Zhang, K., Tong, J., Yang, Z. \& Wu, S., 2001. The Global Stratotype Section and Point (GSSP) of the Permian-Triassic Boundary. Episodes, 24(2): 102114.

Zakharov, Y.D., 2004. The Global Stratotype Section and Point 2 (GSSP) of the base of the Olenekian Stage (Lower Triassic). Albertiana, 29: 38-40.

Zakharov, Y.D., Shigeta, Y., Popov, A.M., Sokarev, A.N., Buryi, G.I., Golozubov, V.V., Panasenko, E.S. \& Dorukhovskaya, E.A., 2000. The candidates of global stratotype of the boundary of the Induan and Olenekian stages of the Lower Triassic in southern Primorye. Albertiana, 24: 12-26. 
Zakharov, Y.D., Popov, A.M. \& Buryi, G.I., 2005a. Unique marine Olenekian-Anisian boundary section from South Primorye, Russian Far East. Journal of China University of Geosciences, 16, 219-230.

Zakharov, Y.D., Popov, A.M. \& Buryi, G.I., 2005 b. Unique Marine Olenekian-Anisian Boundary Section from South Primorye, Russian Far East. Albertiana, 33: 102.

Zakharov, Y.D., Shigeta, Y. \& Igo, Y., 2009. Correlation of the Induan-Olenekian boundary beds in the Tethys and Boreal realm: evidence from conodont and ammonoid fossils. Albertiana, 37: 20-35.

Zakharov, Y.D., Biakov, A.S., Horacek, M., Kutygin, R.V., Sobolev, E.S. \& Bond, D.P.G., 2020. Environmental Control on Biotic Development in Siberia (Verkhoyansk Region) and Neighbouring Areas During Permian-Triassic Large Igneous Province Activity. In: Guex, J., Torday, J.S. \& Miller, W.B. Jr. (eds.), Morphogenesis, Environmental Stress and Reverse Evolution, Springer Nature Switzerland AG, 197-231.

Zapfe, H., 1974. Trias in Österreich. In: Zapfe, H. (ed.), Die Stratigraphie der alpin-mediterranen Trias. Schriftenreihe der Erdwissenschaftlichen Kommissionen, Österreichische Akademie der Wissenschaften, 2: 245-251.

Zapfe, H., 1983. Das Forschungsproject "Triassic of the Tethys Realm" (IGCP Proj. 4). Abschlußbericht. In: Zapfe, H. (ed.), Neue Beiträge zur Biostratigraphie der Tethys-Trias. Schriftenreihe der Erdwissenschaftlichen Kommissionen, Österreichische Akademie der Wissenschaften, 5: 7-16.

Zhang, F., Romaniello, S.J., Algeo, T.J., Lau, K.V., Clapham, M.E., Richoz, S., Herrmann, A.D., Smith, H., Horacek, M. \& Anbar, A.D., 2018. Multiple episodes of extensive marine anoxia linked to global warming and continental weathering following the latest Permian mass extinction. Science Advances, 4(4): e1602921. https:/doi.org/10.1126/sciadv. 1602921
Zhang, L., Orchard, M. J., Algeo, T. J., Chen, Z.-Q., Lyu, Z., Zhao, L., Kaiho, K., Ma, B. \& Liu, S., 2019a. An intercalibrated Triassic conodont succession and carbonate carbon isotope profile, Kamura, Japan. Palaeogeography, Palaeoclimatology, Palaeoecology, 519: 65-83.

https://doi.org/10.1016/j.palaeo.2017.09.001

Zhang, L., Orchard, M.J., Brayard, A., Algeo, T.J., Zhao, L., Chen, Z.-Q. \& Lyu, Z., 2019b. The Smithian / Spathian boundary (late Early Triassic): A review of ammonoid, conodont, and carbon-isotopic criteria. Earth-Science Reviews, 195: 7-36. https://doi.org/10.1016/j.earscirev.2019.02.014

Zhang, L.J., Buatois, L.A., Mángano, M.G., Qi, Y.-A. \& Tai, C., 2018. Early Triassic trace fossils from South China marginal-marine settings: Implications for biotic recovery following the end-Permian mass extinction. GSA Bulletin, 131(1-2): 235-251. https:// doi .org /10.1130/B31867.1

Zuchuat, V., Sleveland, A.R.N., Twitchett, R.J., Svensen, H.H., Turner, H., Augland, L.E., Jones, M.T., Hammer, Ø., Hauksson, B.T., Haflidason, H., Midtkandal, I. \& Planke, S., 2020. A new high-resolution stratigraphic and palaeoenvironmental record spanning the End-Permian Mass Extinction and its aftermath in central Spitsbergen, Svalbard. Palaeogeography, Palaeoclimatology, Palaeoecology, 554: 109732. https://doi.org/10.1016/j.palaeo.2020.109732 